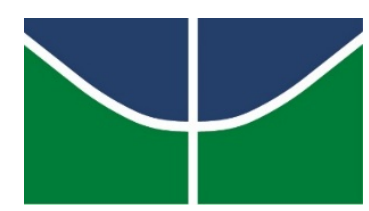

UNIVERSIDADE DE BRASÍLIA

INSTITUTO DE CIÊNCIAS HUMANAS

DEPARTAMENTO DE GEOGRAFIA

PROGRAMA DE PÓS-GRADUAÇÃO EM GEOGRAFIA-PPGEA

Lucas Garcia Magalhães Peres

ANÁLISE TEMPORAL DO USO E COBERTURA DA TERRA NA BACIA HIDROGRÁFICA DO LAGO GRANDE DO CURUAI, PARÁ

Orientadora: Dra. Helen da Costa Gurgel Coorientadora: Dra. Anne-Elisabeth Laques 


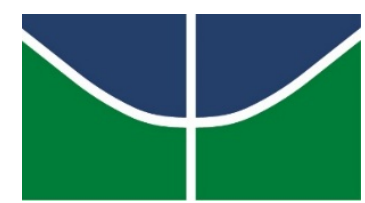

\author{
UNIVERSIDADE DE BRASÍLIA \\ INSTITUTO DE CIÊNCIAS HUMANAS \\ DEPARTAMENTO DE GEOGRAFIA \\ PROGRAMA DE PÓS-GRADUAÇÃO EM GEOGRAFIA-PPGEA
}

Lucas Garcia Magalhães Peres

\title{
ANÁLISE TEMPORAL DO USO E COBERTURA DA TERRA NA BACIA HIDROGRÁFICA DO LAGO GRANDE DO CURUAI, PARÁ
}

Dissertação de Mestrado submetida ao Departamento de Geografia da Universidade de Brasília, como parte dos requisitos necessários para a obtenção do Grau de Mestre em Geografia, área de concentração Gestão Ambiental e Territorial, linha de pesquisa Geoprocessamento, opção Acadêmica.

Aprovado por:

Profa. Dra. Helen da Costa Gurgel

Departamento de Geografia, Universidade de Brasília, Brasília-DF (Orientadora)

Prof. Dr. Carlos Hiroo Saito

Departamento de Ecologia Aplicada/Centro de Desenvolvimento Sustentável, Universidade de Brasília, Brasília-DF

Profa. Dra. Maria Isabel Sobral Escada

Instituto Nacional de Pesquisas Espaciais, São José dos Campos-SP 
PERES, LUCAS GARCIA MAGALHÃES

Análise temporal do uso e cobertura da terra na bacia hidrográfica do Lago Grande do Curuai, Pará (UnB-GEA, Mestre, Geografia, 2016)

Dissertação de Mestrado - Universidade de Brasília. Departamento de Geografia

1. Sensoriamento Remoto 2. Análise Temporal 3.Uso e Cobertura da Terra 4. Bioma Amazônia 5. Métricas de Paisagem 6. Planícies de inundação

I. Universidade de Brasília-Departamento de Geografia

É concedida à Universidade de Brasília permissão para reproduzir cópias desta dissertação e emprestar ou vender tais cópias somente para propósitos acadêmicos e científicos. O autor reserva outros direitos de publicação e nenhuma parte desta dissertação de mestrado pode ser reproduzida sem a autorização por escrito do autor. 


\section{AGRADECIMENTOS}

Em primeiro lugar, agradeço a Deus, pelo dom da vida e por me dar saúde e forças para perseverar em busca dos meus sonhos e objetivos. Que esse trabalho seja só mais um da intensa caminhada a procura do conhecimento! Em segundo lugar, agradeço a Universidade de Brasília. O berço da minha formação, meu lar generoso desde 2010, de quem tenho muito orgulho e me sinto extremamente honrado por ser estudante. A UnB me transformou em quem eu sou, e a ela sou extremamente grato.

Agradeço imensamente as minhas orientadoras, professora Helen Gurgel e professora Anne-Elisabeth Laques. A vocês devo muito do meu crescimento profissional e pessoal dos últimos anos. Obrigada pelo carinho, pela paciência, pelos ensinamentos, pelas oportunidades e pelo imenso aprendizado nessa caminhada iniciada em 2013, durante a minha monografia. Vocês me ensinaram a buscar sempre o melhor de mim e a explorar minhas capacidades. Serei eternamente grato pela oportunidade de trabalhar na Amazônia e exercer com plenitude minha profissão.

Fica registrado também meu enorme agradecimento aos colegas do projeto ClimFABIAM: Álvaro Xavier, Ana Carolina Alcântara, Cleber Kraus, Eudes Bomfim, Eva Haentjens, Gustavo Melo, Julie Roussel, Leonardo Gomes, Marie Flore Doyen, Marie Paule Bonnet, Mariana Câmara, Nivaldo Fonseca, Pierre Bommel, Sebastien Pinel e Yumi Parralego. Nossas missões e experiências em campo ficaram marcadas para sempre em meu coração e memória. Jamais esquecerei dos dias navegando o Lago Grande e o Amazonas a bordo de Isabelle, as noites comendo um peixe frito no bar da Simone ao som de um violão, a correria nas madrugadas para abaixar a lona e escapar dos "aguaceiros", as tardes de "sol rachando" desbravando a TransLago a bordo da caçamba de uma camionete. Tudo isso sempre em um ambiente alegre, profissional e extremamente comprometido com o desenvolvimento das nossas atividades.

Deixo aqui também meu agradecimento ao povo do Lago Grande, em especial ao Gavião, a Simone, ao seu Januário, a Angélica, Gregório e aos alunos da Casa Familiar Rural de Curuai. Essa pesquisa não teria acontecido sem vocês, e é por vocês que a fizemos. Agradeço a vocês por me mostrarem que seu modo de vida, tão distante do meu, garoto urbano do subúrbio, tem sua singularidade e enorme valor. Não há sabedoria maior do que viver as margens do maior rio do mundo e conviver com essas verdadeiras forças da natureza 
que são o rio Amazonas e a Floresta Amazônica. O Lago Grande do Curuai me mostrou que os ribeirinhos têm mais conhecimento sobre a floresta do que qualquer acadêmico.

Agradeço também a minha família, Célio, Tiana e Thainá. Não chegaria aqui sem vocês! Fica também o agradecimento aos meus amigos que me acompanham em minhas caminhadas pela vida: Felipe Jean, João Gabriel, Gustavo Soares, Hygor Viana, Luciana Isabor, Mábia Bastos, Marcus Morato, Marcus Rodrigues, Natália Nunes, Nathália Bariani, Victor Ramon, Phillipe Berlinck e Rayza Dourado. De maneira tão importante, agradeço igualmente a Amanda Tanous: sem seu profissionalismo e apoio, essa trajetória não teria sido concluída, e várias outras sequer teriam sido iniciadas.

Agradeço também as amizades construídas e fortalecidas durante a graduação, e que se empenharam na mesma "louca” caminhada de partir direto para o mestrado: José Roberto, Lucas Lima, Raina Santos e Tiago Rufo. Aos colegas do Laboratório de Geografia, Ambiente e Saúde (LAGAS), Amarílis Bezerra, Bruna Drummond, Krishna Mara, Mariana Santos, e Rogério Vidal, fica minha gratidão pela convivência em nossa sala do módulo 25, em especial nos últimos meses. A descontração e alegria de vocês contribuiu para o bom andamento do meu trabalho. A todos vocês, de coração, meu muito obrigado!

Agradeço também à Coordenação de Aperfeiçoamento de Pessoal de Nível Superior (CAPES), pelo auxílio financeiro para o desenvolvimento das atividades do mestrado; e à FRB (Fondation pour la Recherche sur la Biodiversité), ao IRD (Institut de Recherche pour le Développement, e ao LMI (Laboratório Misto Internacional) pelo apoio para as atividades de campo. 
“Estudar a natureza tão somente para encontrar continuamente novas razões para amá-la”.

Jean-Jacques Rousseau 


\section{RESUMO}

A ocupação do Bioma Amazônia ocorreu de maneira heterogênea em virtude de fatores históricos e geográficos, tendo seu núcleo inicial concentrado nas regiões de planície de inundação, áreas de grande importância econômica, social e ecológica. Esse processo, iniciado séculos antes da ocupação portuguesa, trouxe variados impactos em virtude da complexidade e fragilidade desses ambientes, onde são praticadas atividades agropecuárias e extrativismo. Compreender e analisar esses processos é fundamental num momento em que as pressões sofridas pelo Bioma podem acarretar impactos nas populações locais e interferir nos diversos serviços ambientais que o mesmo presta para o restante do país. Dessa forma, esse estudo pretende analisar dinâmicas de alteração de uso e cobertura da terra em uma região de planície de inundação, próximo a cidade de Santarém (PA), sendo a bacia hidrográfica do Lago Grande do Curuai o foco desse estudo. Para isso foram utilizadas geotecnologias associadas à métricas de paisagens, e uma análise a partir de dois recortes geográficos distintos na mesma área de estudo. O primeiro recorte geográfico é equivalente a toda a bacia hidrográfica, tendo foco na análise da cobertura vegetal natural, correspondente as florestas de terra firme e de várzea; o segundo recorte diz respeito a divisão da área de estudo em seis zonas de paisagem, sendo que essa divisão levou em conta os sistemas produtivos e as características de uso da região em sua delimitação. As geotecnologias fornecem subsídios para a detecção das alterações no ambiente a partir do sensoriamento remoto orbital e no processamento dos dados obtidos. Foram classificadas imagens dos satélites Landsat 5 e 7, dos anos de 1985, 1997 e 2014, numa série de quase 30 anos de estudo. As métricas de paisagem permitiram estabelecer padrões da paisagem, facilitando a comparação entre momentos distintos. As classificações foram validadas por meio de índice Kappa, que utilizou dados coletados em três trabalhos de campo - realizados em 2014 e 2015, nas épocas de cheia e seca - atingindo níveis satisfatórios. No primeiro recorte, as métricas apontam para uma dinâmica moderada entre 1985 e 2014. Nesse período, embora haja uma diminuição das áreas de floresta de terra firme, a classe em que há maior aumento é a de vegetação secundária/capoeira. Ocorrem aumentos das áreas de pastagem, entretanto as áreas de cultivo de roça mantêm-se estáveis; as áreas de pasto e roça ocorreram de forma dispersa no território e em pequenas parcelas durante todo o período estudado; essa dinâmica apontada pela classificação é um indicativo de que as áreas de cultivo ocorrem de forma rotacionada, com a ocupação de áreas diferentes ao longo dos anos, que vão se recuperando com o passar do tempo. No segundo recorte, dentre as seis zonas da paisagem, duas são concentradoras de grande parte dos processos de substituição da cobertura vegetal natural por atividades antrópicas, sendo as zonas 3 e 4 as que tem mais alteração da paisagem. A análise em recortes geográficos distintos permitiu identificar que a área de estudo possui padrões heterogêneos de ocupação no tempo e no espaço. O estudo pode facilitar o planejamento do uso do território, tendo em vista pressões externas e da presença de um assentamento da reforma agrária na área de estudo. 


\begin{abstract}
The occupation of the Amazon Biome occurred heterogeneously due the historical and geographical factors and it was initially concentrated in the floodplain regions, areas of great economic, social and ecological importance. This process, which began centuries before the Portuguese occupation, brought various impacts due the complexity and fragility of floodplain environments, where agricultural and extractive activities are practiced. Understand and analyze these processes is crucial at a time where the pressures suffered by Biome could cause impacts on local populations and interfere in the various environmental services that it provides to the rest of the country. Thus, this study intends to analyze the dynamic of changes in use and land cover in a floodplain region, near to the Satarém (PA) city, the watershed of Grande do Curuai Lake, the focus of this study. For this, technologies have been used associated with landscape metrics, and analysis from two separate geographic clippings in the same area of study. For this, geotechnologies were used associated with landscape metric, and an analysis from two separate geographical units in the same area of study. The first geographical unit is equivalent to the entire watershed, with focus on the analysis of natural vegetation cover, corresponding to the upland forests and floodplain; the second unit corresponds to the division of the study area into six landscape zones, and this division considered the region's production systems and use characteristics on its delimitation. The geotechnologies provide subsidies for the detection of changes in the environment with the use of remote sensing and processing of data. Were classified images from Landsat 5 and 7, of the years of 1985, 1997 and 2014, with a series of nearly 30 years of study. The landscape metrics allowed to establish the landscape patterns and it facilitates the comparison of different times. The classification was validated by Kappa index, which used observed data in three fieldwork in 2014 and 2015, flood period and drought period - reaching satisfactory levels. In the first unit, the metrics indicate a moderate dynamic between 1985 and 2014 . During this period, although there is a decrease in the areas of upland forest, the class in which has a further increase is the vegetation secondary/capoeira. There is an increase of pasture areas, however the farm growing areas are stable; pasture and plantation areas occurred in a dispersed manner in the territory and in small portions throughout the study period; this dynamic appointed by classification is indicative of rotation form of the cultivation, with the occupation of different areas over the years, ranging recovering over time. In the second unit, among the six landscape areas, two are concentrators of a large part of the replacement process of natural vegetation by human activities, and the 3 and 4 zones are the areas wich have more change in the landscape. The analysis in different geographic units allowed identify that the study area has heterogeneous occupation patterns in time and space. The study may facilitate the planning of land use, considering external pressures and the presence of a rural settlement of the agrarian reform in the study area pressures. The study may facilitate the planning of land use, considering external pressures and the presence of a rural settlement of the agrarian reform in the study area.
\end{abstract}


RESUMO

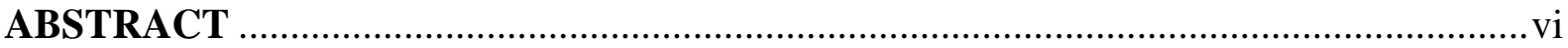

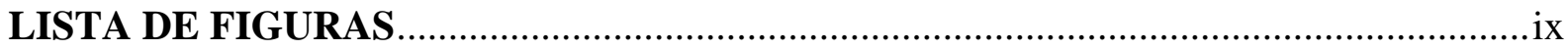

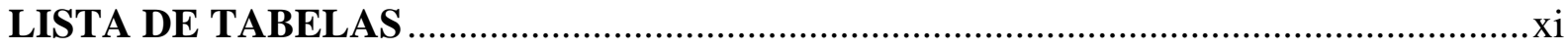

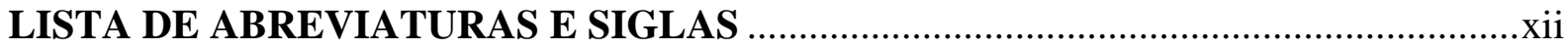

1. INTRODUÇÃ

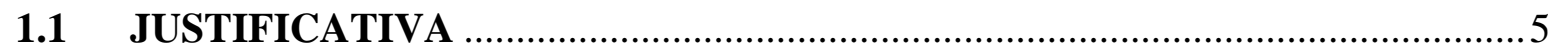

1.2 OBJETIVOS

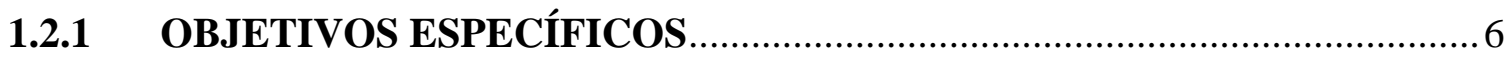

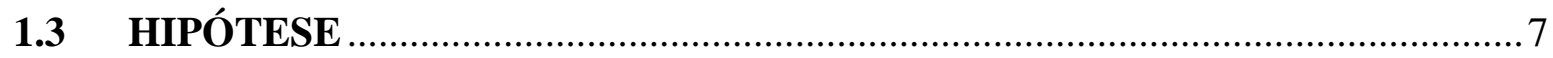

1.4 LAGO GRANDE DO CURUAI: ANÁLISE ESPAÇO-TEMPORAL A PARTIR DAS GEOTECNOLOGIAS E DAS MÉTRICAS DE PAISAGEM ............................ 7

1.4.1 CARACTERÍSTICAS GERAIS DA BACIA HIDROGRÁFICA DO LAGO

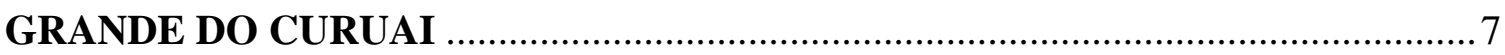

1.4.2 HISTÓRICO DE USO E OCUPAÇÃO ................................................... 13

1.4.3 GEOTECNOLOGIAS E MONITORAMENTO DE MUDANÇAS DE USO

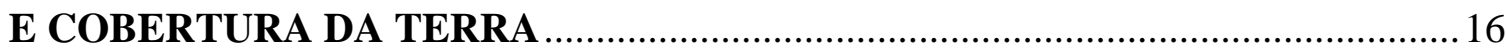

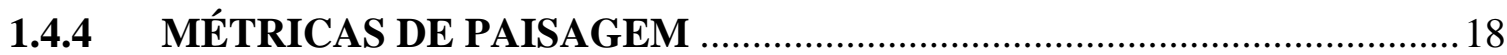

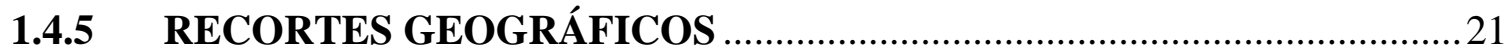

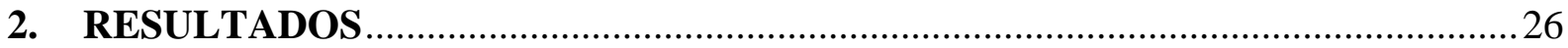

ANÁLISE DA DINÂMICA DAS PAISAGENS DA BACIA HIDROGRÁFICA DO

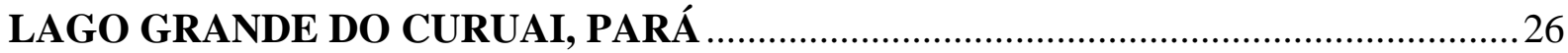

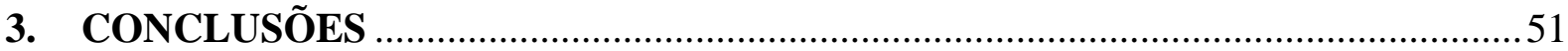

ANEXO A: Matriz de confusão comparando os resultados da classificação (linhas) com os dados de referência de campo (colunas) - 1985 ............................................................58 
ANEXO B: Matriz de confusão comparando os resultados da classificação (linhas) com os dados de referência de campo (colunas) - 1997

ANEXO C: Matriz de confusão comparando os resultados da classificação (linhas) com os dados de referência de campo (colunas) - 2014

ANEXO D: Métricas da paisagem aplicadas no recorte geográfico da bacia

ANEXO H: Mapa de Classificação de Uso e Cobertura do Solo - 1985 .66

ANEXO I: Mapa de Classificação de Uso e Cobertura do Solo - 1997.

ANEXO J: Mapa de Classificação de Uso e Cobertura do Solo - 2015 68

ANEXO L: Amostras das classes de uso e cobertura em imagens Landsat e do Google Earth. Fonte: elaborado pelo autor. .70 


\section{LISTA DE FIGURAS}

Figura 1: Biomas brasileiros. Fonte: elaborado pelo autor.......................................... 1

Figura 2: Conjuntura, problemáticas e desafios norteadores da pesquisa ........................ 6

Figura 3: Localização da Área de Estudo. Fonte: elaborado pelo autor...........................8

Figura 4: A: Área de vegetação secundária ao longo de rodovia da região; B: Área de remanescentes florestais com menor grau de perturbação antrópica, localizados ao sul da região de estudo. Fonte: elaborado pelo autor.

Figura 5: Criação de Gado (A) e plantação de mandioca (B). Fonte: elaborado pelo autor.

Figura 6: Região com manchas de Cerrado, localizadas na porção leste da área de estudo. Fonte: elaborado pelo autor. 10

Figura 7: Localização do PAE Lago Grande. Fonte: elaborado pelo autor.

Figura 9: Esquematização do ciclo de inundação nas planícies amazônicas Fonte: adaptado de Junk (1984).

Figura 8: Inundação na Vila do Torrão do Papa Terra, região do Lago Grande do Curuai. Acima, imagem de maio de 2014, período da cheia; abaixo, imagem de novembro de 2014, período de seca. Fonte: elaborado pelo autor. 12

Figura 10: Produção de Farinha de Mandioca nas proximidades da Vila de Piraquara, maio de 2014. Fonte: elaborado pelo autor 13

Figura 11: Pecuária sendo praticada na região da várzea durante a seca (novembro de 2014). Fonte: elaborado pelo autor.

Figura 12: Zonas da Paisagem da Bacia Hidrográfica do Lago Grande do Curuai. Fonte: elaborado pelo autor.

Figura 13: Localização da Área de Estudo. Fonte: elaborado pelo autor.

Figura 14: Delimitação das Zonas da Paisagem (segundo recorte geográfico de estudo). Fonte: elaborado pelo autor 36

Figura 15: Métricas Aplicadas na Recorte Espacial da Bacia: Número de Fragmentos (em valores totais), Área da Classe e Tamanho Médio do Fragmento (em hectares), Índice de Forma Médio (Variação entre 1 e 2).

Figura 16: Métricas aplicadas no recorte espacial das Zonas da Paisagem (Zonas 1 e 2): Número de Fragmentos (em valores totais), Área da Classe e Tamanho Médio do Fragmento (em hectares). 42 
Figura 17: Métricas aplicadas no recorte espacial das Zonas da Paisagem (Zonas 3 e 4): Número de Fragmentos (em valores totais), Área da Classe e Tamanho Médio do

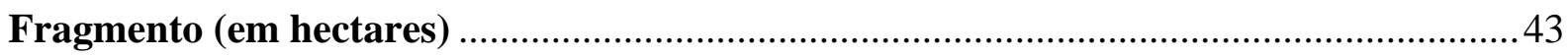

Figura 18: Métricas aplicadas no recorte espacial das Zonas da Paisagem (Zonas 5 e 6): Número de Fragmentos (em valores totais), Área da Classe e Tamanho Médio do

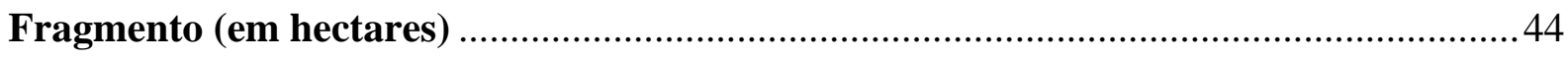




\section{LISTA DE TABELAS}

Tabela 1: Exemplos de Métricas da Paisagem disponíveis nos programas Fragstats e Patch Analyst. Fonte: adaptado de McGarigal and Marks (1995)

Tabela 2: Descrição das Características das Zonas da Paisagem (segundo recorte geográfico de estudo). Fonte: elaborado pelo autor.

Tabela 3: Imagens Landsat utilizadas. Fonte: elaborado pelo autor. 31 


\section{LISTA DE ABREVIATURAS E SIGLAS}

Clim-FABIAM - Changecments climatiques et biodiversité des lacs d'inondation dans le bassin Amazonien: Comment faire face et aider à la durabilité écologique et économique DETER - Detecção de Desmatamento em Tempo Real

EMBRAPA - Empresa Brasileira de Pesquisa Agropecuária

ETM+- Enhanced Temathic Mapper

FEAGLE - Federação das Associações de Moradores e Comunidades do Assentamento Agroextrativista da Gleba Lago Grande

FRB - Fondation pour la recherche sur la biodiversité

GPS - Global Positioning System

IBGE - Instituto Brasileiro de Geografia e Estatística

IBAMA - Instituto Brasileiro do Meio Ambiente e dos Recursos Naturais Renováveis

IMAZON - Instituto do Homem e Meio Ambiente da Amazônia

INCRA - Instituto Nacional de Colonização e Reforma Agrária

INPE - Instituto Nacional de Pesquisas Espaciais

IRD - Institut De Recherche Pour Le Développement

LAGAS - Laboratório de Geografia, Ambiente e Saúde

LMI/OCE - Laboratório Misto Internacional/Observatório das Mudanças Climáticas

MMA - Ministério do Meio Ambiente

NASA - National Aeronautics and Space Administration

PAE - Projeto de Assentamento Agroextrativista

PIB - Produto Interno Bruto

PRODES - Monitoramento do desmatamento das formações florestais na Amazônia Legal

SIG - Sistema de Informações Geográficas

RMS - Root Mean Square

SRTM - Shuttle Radar Topography Mission

TerraClass - Projeto de Monitoramento do uso da terra nas áreas desflorestadas da Amazônia Legal

TM - Thematic Mapper

UnB - Universidade de Brasília

USGS - United States Geological Survey 


\section{INTRODUÇÃO}

Estendendo-se por aproximadamente 49,29\% (4.196.943 km²) do território brasileiro, que corresponde à soma da área de cinco unidades da federação (Acre, Amapá, Amazonas, Pará e Roraima), e a parcialidade de Rondônia, Mato Grosso, Maranhão e Tocantins (IBGE, 2004), o Bioma ${ }^{1}$ Amazônia (Figura 1) possui grande diversificação de fauna e flora, além de toda uma cadeia de microrganismos que contribui para o equilíbrio ecológico do bioma. Com dimensões continentais, sua extensão territorial é superior à de toda a Europa Ocidental (3.662.448,95 km²), parcela do continente europeu que engloba países como Alemanha, Espanha, França, Itália e Reino Unido.

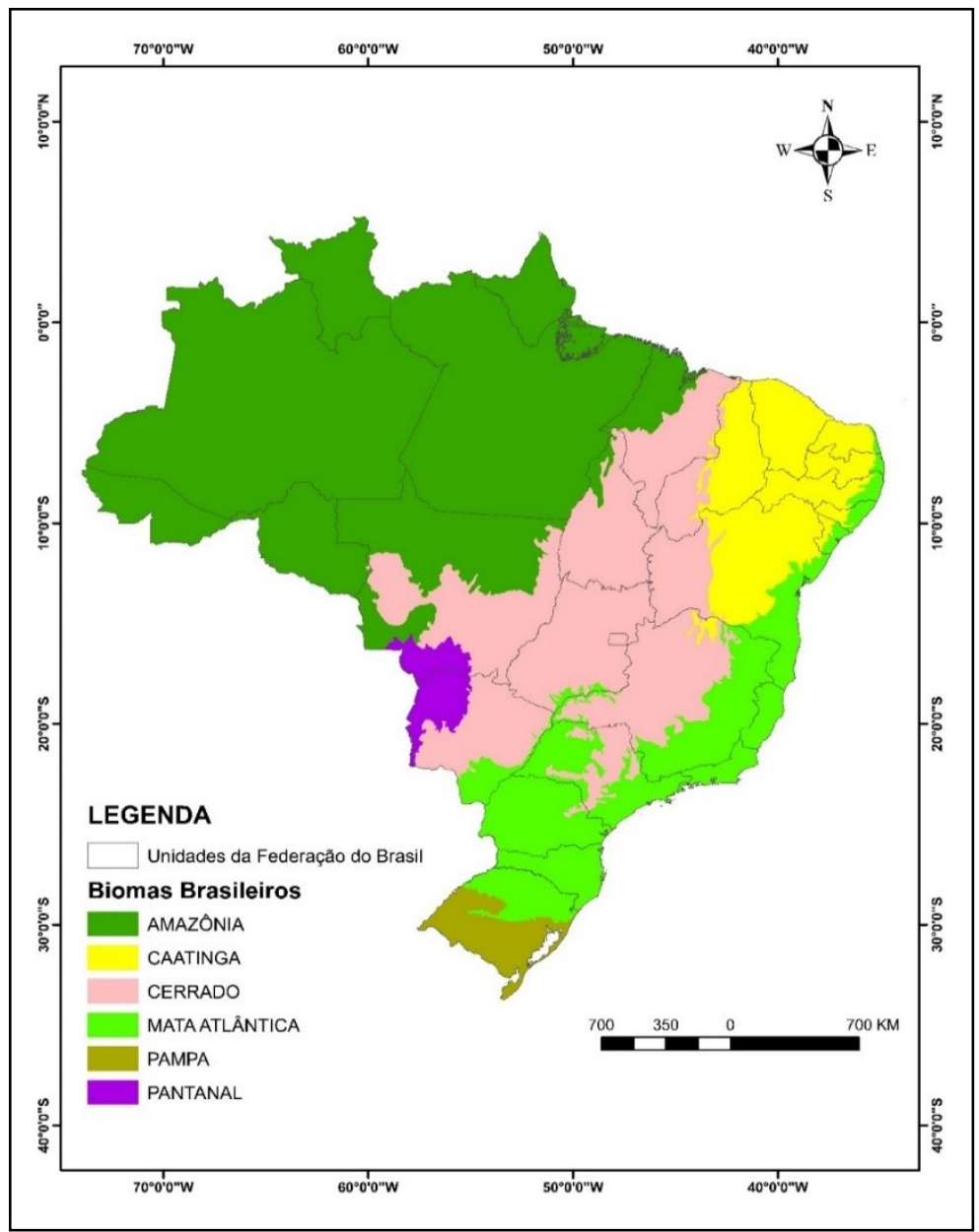

Figura 1: Biomas brasileiros. Fonte: elaborado pelo autor.

\footnotetext{
${ }^{1}$ Bioma é um conjunto de vida vegetal e animal, constituído pelo agrupamento de tipos de vegetação contíguos e que podem ser identificados a nível regional, com condições de geologia e clima semelhantes e que, historicamente, sofreram os mesmos processos de formação da paisagem, resultando em uma diversidade de flora e fauna própria (IBGE, 2004).
} 
Segundo o IBGE (2004), os critérios unificadores para a descrição desse bioma seriam a dominância de seu clima quente e úmido, da fisionomia florestal, sua continuidade geográfica e localização equatorial, além de estar inserido no contexto da maior rede hidrográfica do mundo, que é a bacia Amazônica. Afora toda a diversidade de aspectos naturais, o Bioma Amazônia abriga um diverso e expressivo mosaico socioambiental, onde se inserem populações urbanas, ribeirinhas, indígenas, extrativistas, quilombolas e assentados. O processo de ocupação da região é secular e intensificou-se a partir do governo militar (19641985), que criou diversos projetos baseados na distribuição de terras, na exploração mineral e vegetal e na colonização do território. O impacto desta ocupação causa alterações na paisagem amazônica, que por si só, já é diversa: o bioma abriga diversos elementos, desde os cerrados de Rondônia, os lavrados roraimenses, as matas de "terra firme”, até as várzeas dos grandes rios, como o Amazonas.

Os principais tributários do rio Amazonas são acompanhados ao longo de seus cursos, por extensas planícies de inundações chamadas várzeas ou igapós. Segundo Melack e Hess (2011), as planícies de inundação correspondem a cerca de 800.000 km² de extensão, representando 19\% do total do Bioma Amazônia. Ricos em recursos naturais e de grande importância social (Renó, 2010), as regiões de várzea da bacia Amazônica são constituídas por ecossistemas frágeis e vulneráveis à ações antrópicas e à eventos climáticas extremos. A ocupação das áreas de várzea no Bioma Amazônia é bastante antiga, datando de séculos antes da colonização europeia na América do Sul. A principal marca da ocupação humana no Bioma, tanto nas regiões de várzea como em terra firme, é a descaracterização da paisagem original, cuja expressão mais visível é a retirada da cobertura vegetal natural. Segundo o INPE (2015), estima-se que cerca de $760.305 \mathrm{~km}^{2}$ de floresta da cobertura original do Bioma (18,11\% do total) já tenham sido suprimidos.

Vários estudos analisaram os impactos do desmatamento e das alterações de uso e cobertura da terra na região, demonstrando como consequência a redução da capacidade fértil dos solos, o aumento da emissão de gases de efeito estufa para a atmosfera e alterações nos regimes hidrológico e de chuvas. Foley (et al, 2007) e Sampaio (et al, 2007) apresentam, em simulações, que a perda contínua de floresta conduziria a região a ter um clima mais quente e seco. Segundo Sampaio (et al. 2007), se for mantida a tendência de desmatamento, uma queda abrupta da quantidade de chuva poderá ocorrer se o desmatamento alcançar $40 \%$ da cobertura vegetal original. Essa perspectiva era baseada na taxa de desmatamento da época, que embora 
tenha sofrido uma vertiginosa queda (em 2005 a taxa era de aproximadamente $27.000 \mathrm{~km}^{2}$ ao ano), se mantem com valores expressivos, acima dos 5 mil $\mathrm{km}^{2}$ ao ano.

Além das mudanças de uso e cobertura da terra interferirem de maneira significativa no equilíbrio de dinâmicas naturais e no modo de vida local, essas mudanças podem interferir nos diversos serviços ambientais que a floresta presta para todo o país. Parte da produção agrícola e de energia elétrica do Brasil provêm da região. Além disso, a dinâmica atmosférica da América do Sul transfere umidade do Bioma Amazônia para as regiões sul e sudeste do Brasil, contribuindo significativamente com o regime de chuvas nas regiões responsáveis pela maior parte do PIB do Brasil (Nobre, 2014).

Nas áreas de várzea, o desflorestamento gera variados impactos, tanto sobre os ecossistemas terrestres como também sobre a biodiversidade dos sistemas aquáticos (Costa et al., 2007; Junk, 1996; Parolin, 2002; Wittmann et al., 2004), afetando também a circulação da água nas várzeas (Barbosa, 2005), a pesca, prejudicando a qualidade da água e causando efeitos na saúde das populações ribeirinhas (Junk, 1996). Hess (2003) e Renó (2010) dedicaram esforços em compreender as dinâmicas de uso e ocupação das várzeas do Bioma Amazônia.

Empregando imagens de radar, Hess (2003) mapeou a cobertura vegetal das regiões de várzea do rio Solimões/Amazonas à montante e a jusante de Manaus, identificando um maior grau de preservação nas várzeas a montante da capital amazonense. Renó (2010), utilizandose de imagens da série Landsat, mapeou temporalmente a região de várzea do Baixo Amazonas entre 1970 e 2008, construindo um mapa histórico de cobertura vegetal das áreas à jusante de Manaus. Como resultado, foi apontada uma redução de até 56\% da cobertura vegetal natural nas áreas várzea desde a década de 70. Dentre as áreas localizadas na várzea do Rio Amazonas a jusante de Manaus, destaca-se a bacia hidrográfica do Lago Grande do Curuai.

Formada por um complexo de mais de trinta lagos interconectados e ligada ao rio Amazonas e as áreas de terra firme por igarapés (Bourgoin et al, 2007), a bacia hidrográfica do Lago Grande do Curuai localiza-se entre os municípios de Santarém, Juruti e Óbidos, no estado do Pará. É representativa dos sistemas de várzea do Bioma Amazônia tanto em seus aspectos naturais, como também nos aspectos de uso e ocupação; possui um histórico de apropriação do território antigo e considerável variabilidade de ecossistemas, como as áreas de várzea e florestas e manchas de savanas em terra firme (Folhes, 2012). Em seus aspectos 
naturais, a dinâmica de cheia e seca, condicionada pelo pulso de inundação do rio Amazonas, é determinante para o calendário de atividades econômicas e sociais da região. Essa dinâmica natural dos ciclos de inundação traz um importante aporte de nutrientes condicionado ao ciclo seca-enchente-cheia-vazante.

Na região da bacia hidrográfica do Lago Grande do Curuai, o extrativismo vegetal e animal e a produção de farinha de mandioca são as mais importantes atividades de subsistência, enquanto a pecuária e a pesca possuem maior rentabilidade econômica. Isto posto, essa região está sujeita a pressões antrópicas, por conta das atividades agropecuárias, que podem causar distúrbios nos sistemas naturais e impactos na vida dos ribeirinhos. Diante desse contexto e considerando que os impactos socioambientais que a ocupação humana pode causar sobre a dinâmica dos sistemas naturais das áreas de várzea, este estudo tem como finalidade identificar temporalmente quais padrões de uso e cobertura da terra ocorrem na bacia hidrográfica do Lago Grande do Curuai, utilizando dados de sensoriamento remoto orbital e métricas de paisagem, de forma a identificar alterações nesses padrões.

O desenvolvimento desta pesquisa é parte integrante do projeto intitulado ClimFABIAM - Changecments climatiques et biodiversité des lacs d'inondation dans le bassin Amazonien: Comment faire face et aider à la durabilité écologique et économique. O projeto Clim-FABIAM foi financiado pela Fundação Francesa de Pesquisa sobre a Biodiversidade (FRB) e desenvolvido no quadro do Laboratório Misto Internacional (LMI/OCE) da Universidade de Brasília. O projeto foi executado em parceria entre o Institut de Recherche pour le Développement (IRD) e diversas instituições, entre elas, o Laboratório de Geografia, Ambiente e Saúde (LAGAS) da Universidade de Brasília.

O Clim-FABIAM consiste num projeto franco-brasileiro multidisciplinar, estudando a Geografia, a Antropologia, a Limnologia e a Hidrologia da bacia hidrográfica do Lago Grande do Curuai, com foco no estudo da dinâmica aquática e socioambiental da várzea e da terra firme, e em suas respostas frente a mudanças ambientais em escala local e regional nas várzeas amazônicas. O projeto tem como objetivo fornecer indicadores espacializados e ferramentas para acompanhamento das dinâmicas terrestres e aquáticas, através de dados in situ, modelagem hidrológica e sensoriamento remoto. Além disso, o projeto prevê uma abordagem social com as populações locais, reconhecendo suas percepções acerca das mudanças ambientais e de suas estratégias adaptativas prevendo mudanças futuras.

Esta dissertação está estruturada em 3 capítulos; este primeiro capítulo, introdutório, que apresenta os aspectos gerais e norteadores da pesquisa. O capítulo 2, que apresenta a 
metodologia aplicada e os resultados obtidos com a pesquisa e as discussões. O capítulo está no formato de um artigo científico, que será submetido ao periódico ACTA AMAZÔNICA (ISSN 0044-5967). No capítulo 3, apresenta-se a conclusão geral da pesquisa realizada e que deu como fruto essa dissertação de mestrado; por fim, são apresentadas as referências bibliográficas juntamente com os anexos elaborados durante o desenvolvimento desse manuscrito. Devido a limitações do artigo, figuras, tabelas, mapas e gráficos correspondentes aos resultados também se encontram em anexo (Anexos de $\mathbf{A}$ a $\mathbf{J}$ ).

\subsection{JUSTIFICATIVA}

A justificativa em relação ao estudo na região de várzea se dá pela fragilidade desses ambientes, sendo extremamente vulneráveis as alterações do espaço natural. Os ambientes de várzea no Amazonas são considerados hotspots de biodiversidade e estão entre os mais ricos e produtivos do mundo (Junk, 1984). Além disso, essa é a região primária de ocupação do bioma, tendo uma dinâmica de ocupação, antropização e de atividades econômicas singulares e distintas de outras regiões. As margens dos rios e as várzeas são ambientes frágeis, que ainda concentram grande parte da população da região, e estão suscetíveis as alterações climáticas (IBAMA, 2005).

Balbinot (et al, 2008) expõe que as bacias hidrográficas são vulneráveis às alterações da vegetação, sendo que essas alterações interferem nas propriedades do solo, refletindo também nas propriedades da água dos rios e no ciclo hidrológico como um todo. Ao mesmo tempo, a região de várzea possui uma dinâmica natural extraordinária, explicitada pelo regime de cheia e seca causado pelo pulso de inundação do rio Amazonas, o que produz ambientes distintos e influenciados pelo nível da água durante o ano, interferindo nas atividades antrópicas. Dessa maneira, o aspecto socioambiental das várzeas é particular e torna-se necessário compreender melhor essa dinâmica.

\subsection{OBJETIVOS}

As geotecnologias associadas as métricas de paisagem podem ser ferramentas de análise das mudanças do uso e cobertura da terra e para compreensão dessas dinâmicas. Dessa forma, esta pesquisa de mestrado tem como foco o estudo da dinâmica de uso e cobertura da terra na bacia hidrográfica do Lago Grande do Curuai, tendo como base o uso de métricas paisagem e 
geotecnologias, para identificar e caracterizar alterações temporais de uso e cobertura da terra (Figura 2).

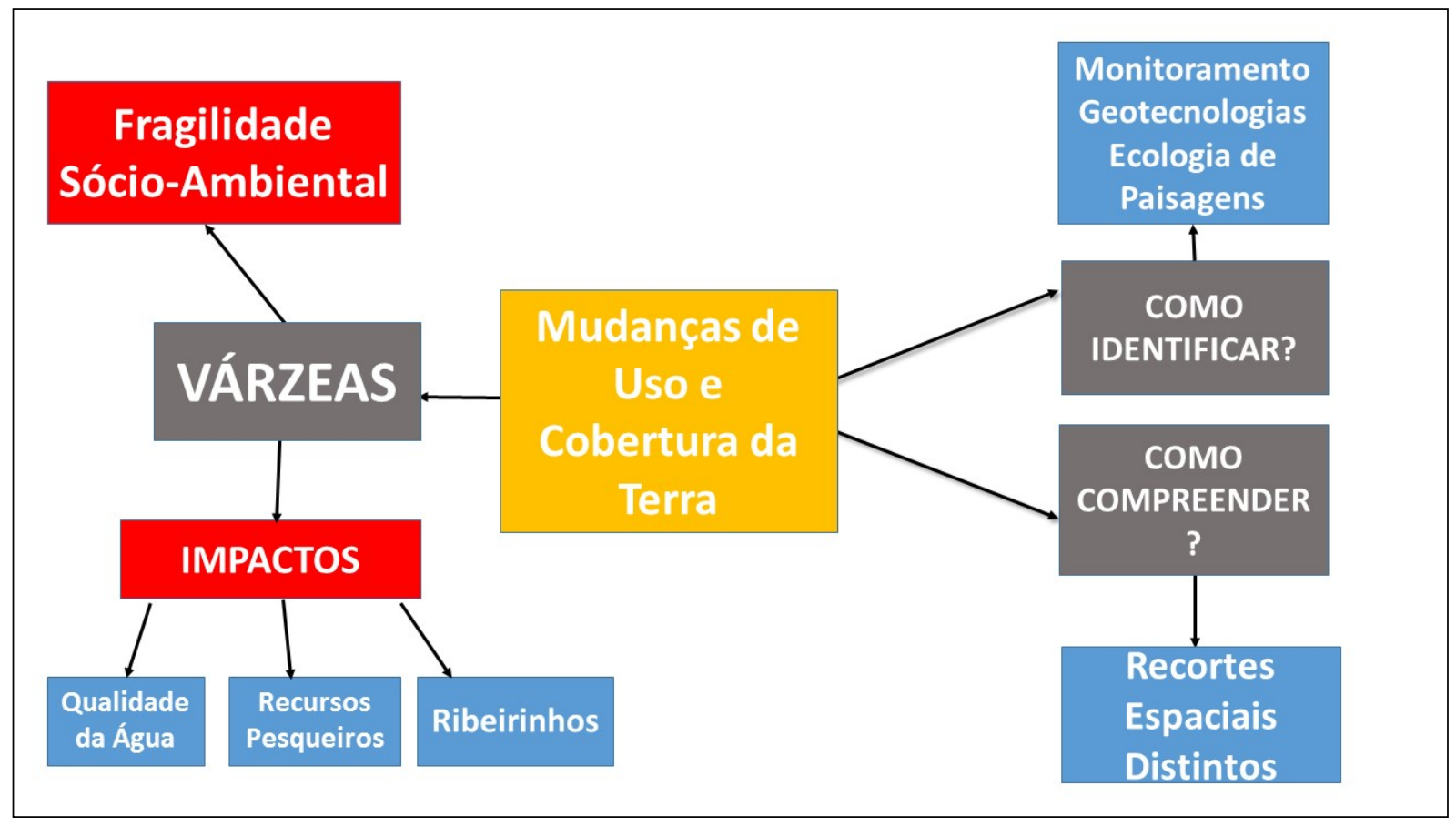

Figura 2: Conjuntura, problemáticas e desafios norteadores da pesquisa

O objetivo geral da pesquisa é a identificação e caracterização das dinâmicas espaçotemporais de uso e cobertura da terra na bacia hidrográfica do Lago Grande do Curuai, com o uso de sensoriamento remoto, geotecnologias e métricas de paisagem.

\subsubsection{OBJETIVOS ESPECÍFICOS}

Os objetivos específicos da pesquisa são:

a) Analisar a dinâmica espaço-temporal do uso e cobertura da terra na bacia hidrográfica do Lago Grande do Curuai, região do Baixo Amazonas, estado do Pará, a partir da classificação de imagens de satélite oriundas de sensores orbitais, no intervalo de tempo compreendido pelos anos de 1985, 1997 e 2014. 
b) Aplicar métricas de paisagens no resultado das classificações das imagens de satélite, de forma a determinar padrões de uso e ocupação e compará-los, a fim de identificar e compreender mais adequadamente as dinâmicas de uso e cobertura da terra.

c) Analisar a dinâmica espaço-temporal de uso e cobertura da terra em dois recortes geográficos distintos: um primeiro, correspondente a toda a área de estudo, e um segundo, correspondendo a um recorte de seis zonas da paisagem, de forma a identificar diferenças entre elas e apontar singularidades entre os recortes estudados.

\subsection{HIPÓTESE}

A hipótese desta pesquisa de mestrado é que as dinâmicas espaço-temporais de uso e ocupação da terra em regiões do Bioma Amazônia, fruto da associação entre processos históricos e aspectos naturais, podem ser identificadas e analisadas por meio de métricas de paisagens; além disso, os estudos da dinâmica de uso e cobertura da terra podem ser embasados por distintos recortes geográficos, identificando heterogeneidades espaciais da distribuição desse fenômeno pela área de estudo.

\subsection{LAGO GRANDE DO CURUAI: ANÁLISE ESPAÇO-TEMPORAL A PARTIR DAS GEOTECNOLOGIAS E DAS MÉTRICAS DE PAISAGEM}

\subsubsection{CARACTERÍSTICAS GERAIS DA BACIA HIDROGRÁFICA DO LAGO GRANDE DO CURUAI}

A bacia hidrográfica do Lago Grande do Curuai (Figura 3) está localizada 850 km acima da foz do rio Amazonas, inserida nos municípios de Juruti, Óbidos e Santarém, no estado do Pará. A região é compreendida como uma bacia pois é a bacia de um lago, que recebe água de vários tributários em terra firme, além de água do rio Amazonas. Além disso, a bacia é composta por diversos lagos menores. A sede do município de Juruti localiza-se dentro da bacia; a sede do município de Santarém distancia-se da região por $110 \mathrm{~km}$, sendo alcançada por barco em viagens que variam entre 8 e 12 horas. Quanto ao transporte terrestre, é cortada pela rodovia PA-257 (TransLago), que não possui asfaltamento. A extensão da bacia hidrográfica é de aproximadamente $3.807,54 \mathrm{~km}^{2}$. A região foi visitada em três trabalhos de campo para coleta de dados e informações, realizados na época da cheia (maio de 2014 e maio de 2015) e na época da seca (novembro de 2014). Os dois principais ambientes da bacia hidrográfica do Lago Grande do Curuai são a região de várzea, suscetível as inundações do 
pulso sazonal do rio Amazonas, e a terra firme. A região constitui-se num diversificado mosaico de paisagens, formas de uso e ocupação, variando das áreas da planície de inundação na várzea até as zonas de remanescentes florestais em terra firme (Anexo K).

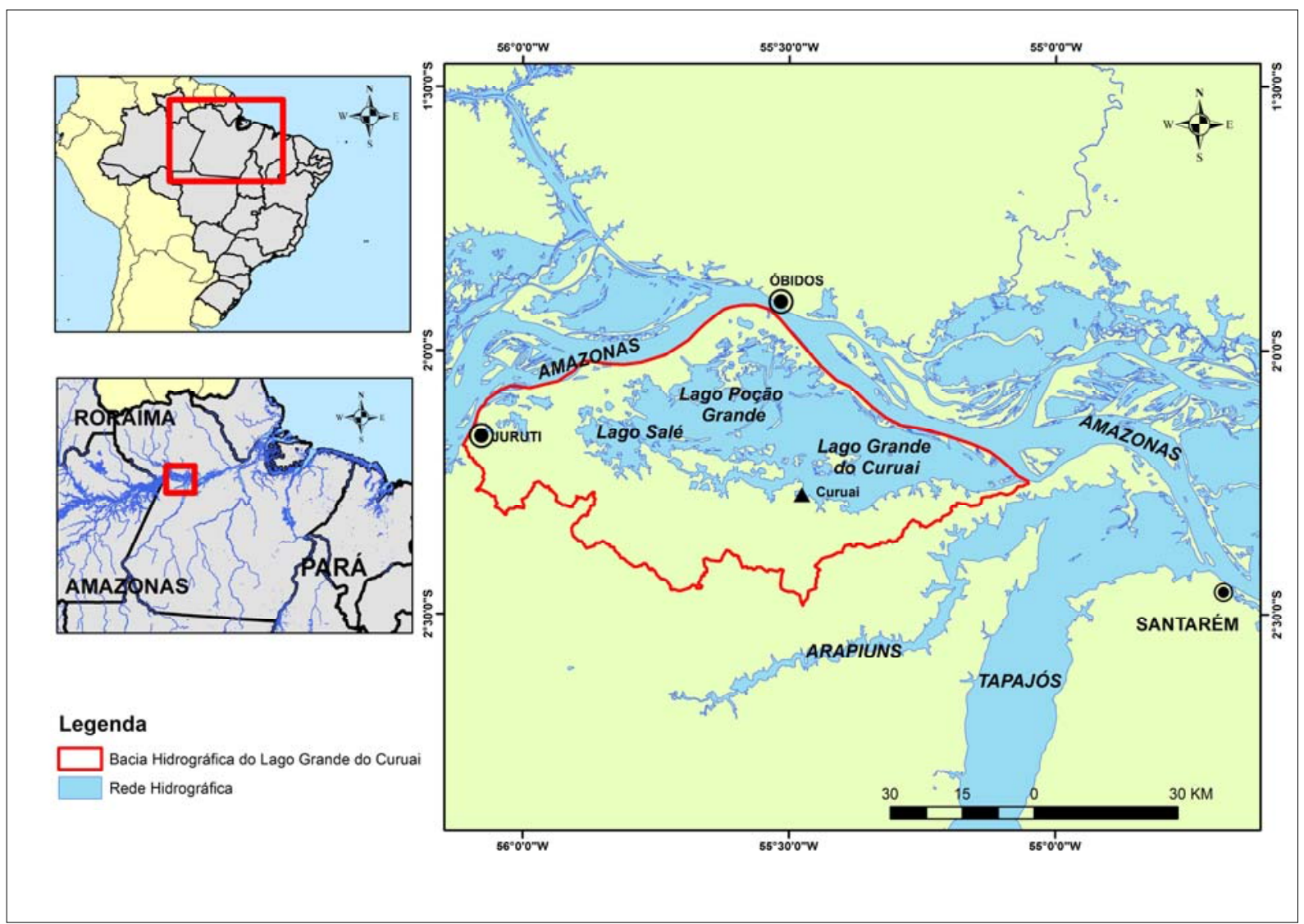

Figura 3: Localização da Área de Estudo. Fonte: elaborado pelo autor.

A várzea é a parte da planície de inundação que oscila entre as fases terrestre e aquática (Alcântara et al, 2007). Conforme aponta Megonigal (et al, 1997), as várzeas apresentam-se como grandes centros de biodiversidade e biocomplexidade. As enchentes alcançam valores máximos de até 15 metros em algumas regiões da calha do rio Amazonas, e se devem à variação sazonal no regime de chuvas dos afluentes de ambas as margens e de sua própria cabeceira (Junk, 1984). Na região do Lago Grande do Curuai, a subida das águas isola algumas vilas localizadas dentro da planície de inundação, como Piedade e Torrão do Papa Terra; nas vilas em terra firme, como Curuai e Piraquara, as cheias inundam portos e as ruas mais próximas aos cursos d’água. As regiões de “terra firme” são as áreas não suscetíveis aos ritmos das cheias dos rios da região Amazônica. Rodrigues e Oliveira (1997) afirmam que "as áreas de Terra Firme não sofrem inundação e são formadas a partir de sedimentos terciários”. 
O clima da região tem duas estações distintas e bem definidas, sendo constituído pelo período do inverno - quando chove em grandes volumes - e o verão - época de seca e volume de chuva reduzido (Bourgoin et al, 2007). Em termos geomorfológicos, segundo Lucas (1989), a região apresenta uma litologia correspondente à formação Alter do Chão, constituída por solos pobres em nutrientes, compostos por depósitos aluviais recentes dispostos em camadas de solo que variam entre 10 e 20 metros de espessura. A tipologia original de vegetação era a floresta ombrófila densa e campinas em terra firme, e vegetação gramínea e herbácea nas áreas inundáveis (IBGE, 2004). Entretanto, devido aos usos antrópicos, a atual caracterização da área indica uma grande presença de áreas de vegetação secundária (Figura 4-A), intercaladas com remanescentes florestais; todavia, os indivíduos de maior porte, como castanheiras e ipês são pouco presentes, localizando-se mais ao sul da bacia, em áreas mais preservadas (Figura 4-B). Ainda em termos de vegetação natural, há manchas de cerrado localizadas no oeste da bacia, devido a condicionantes litológicas (Figura 6). Ocorrem diversas áreas de pastagens e roças de forma difusa no espaço, estando pouco conectadas e tendo em geral pequena extensão espacial (Figura 5-A e 5-B).

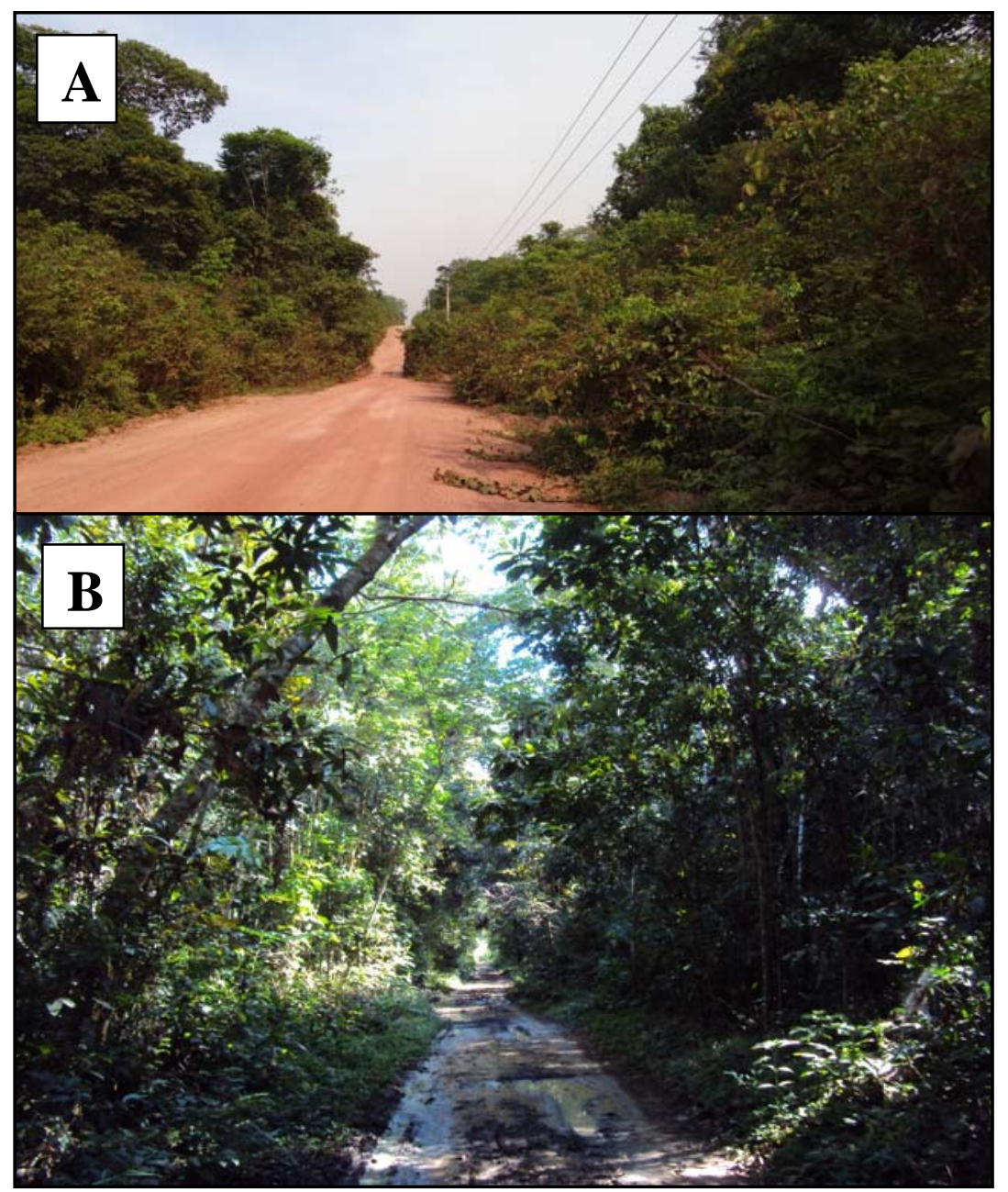

Figura 4: A: Área de vegetação secundária ao longo de rodovia da região; B: Área de remanescentes 9 florestais com menor grau de perturbação antrópica, localizados ao sul da região de estudo. Fonte: elaborado pelo autor. 


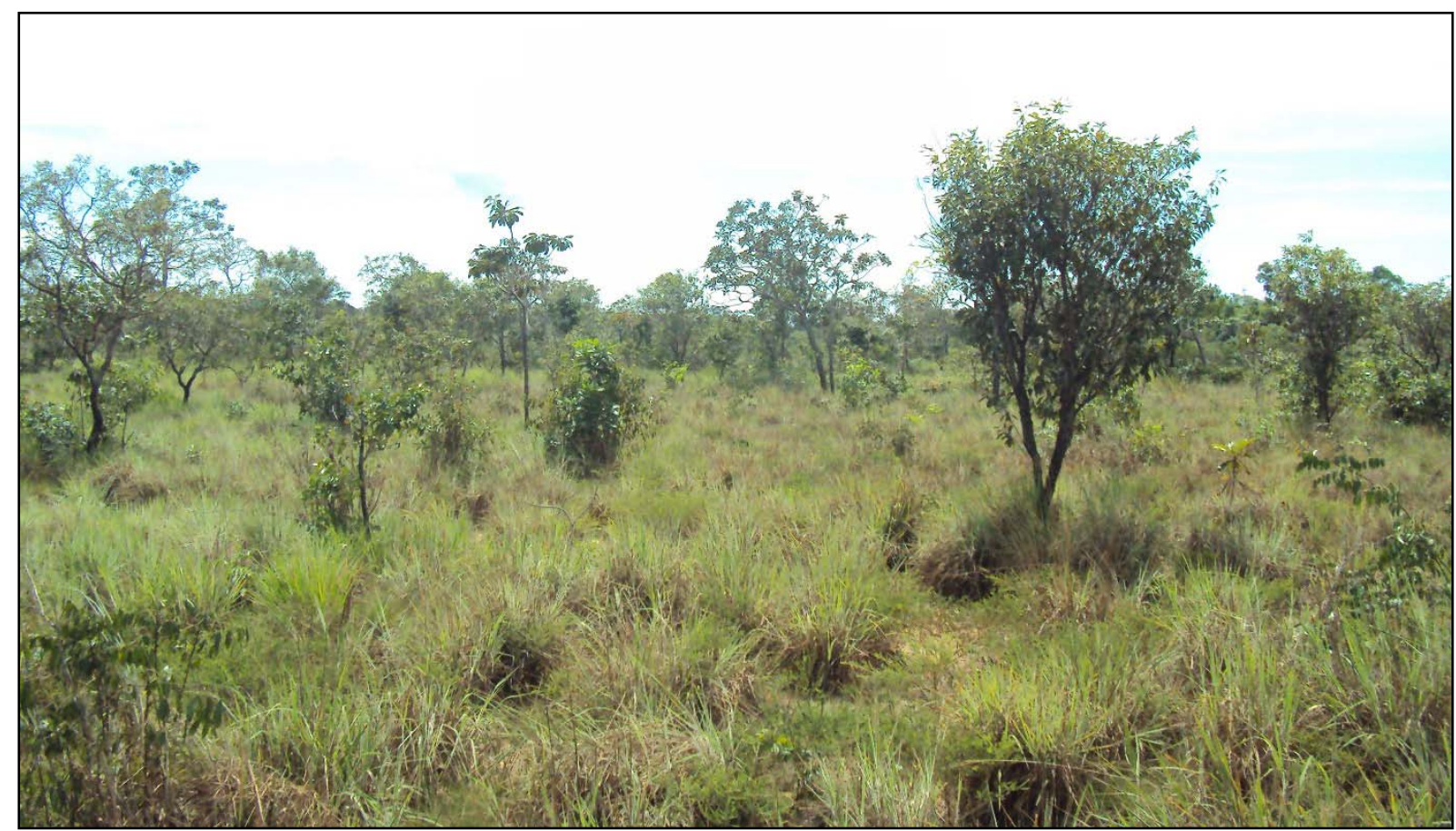

Figura 6: Região com manchas de Cerrado, localizadas na porção leste da área de estudo. Fonte: elaborado pelo autor.
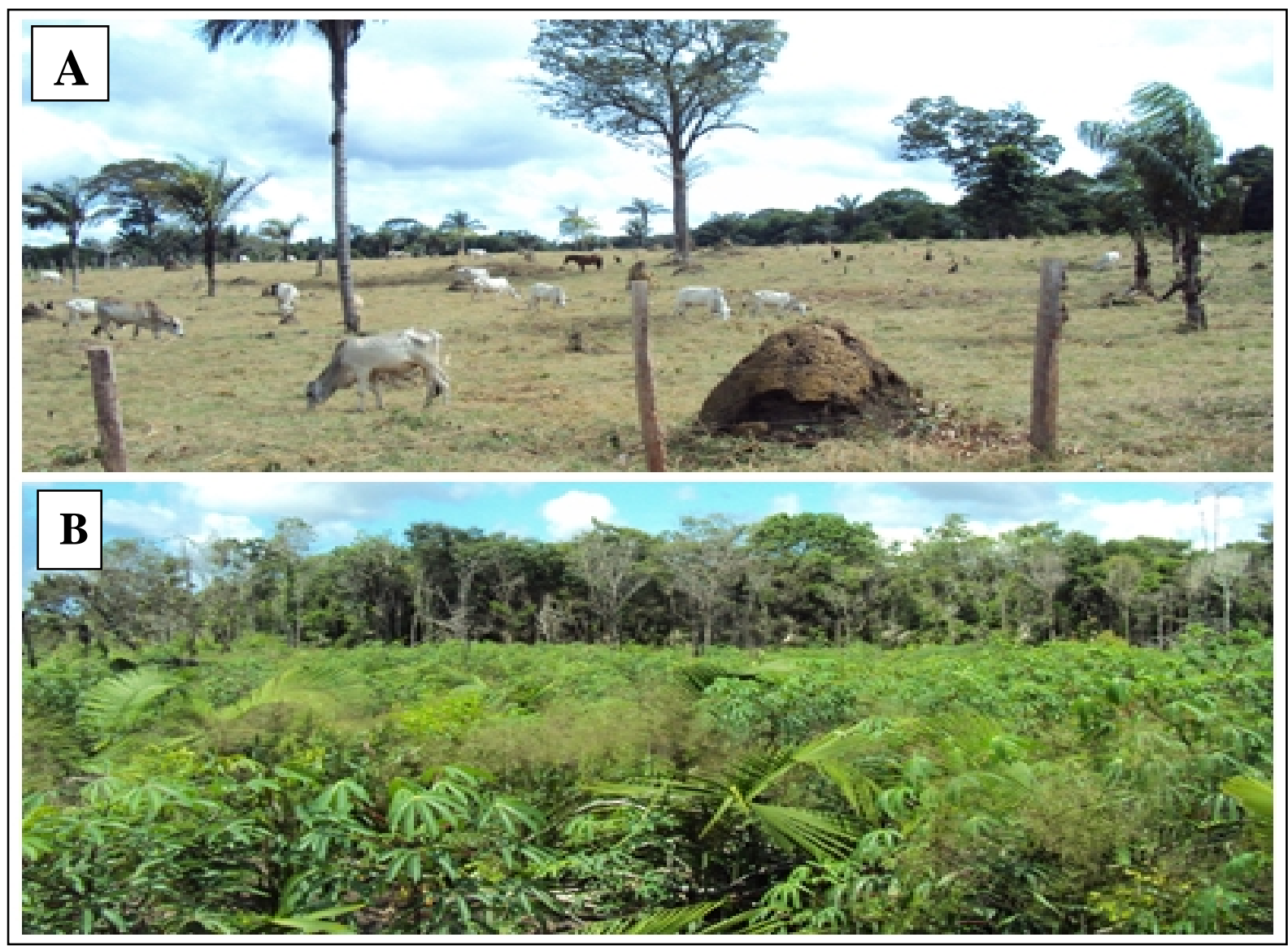

Figura 5: Criação de Gado (A) e plantação de mandioca (B). Fonte: elaborado pelo autor. 
No entorno do lago existem 147 comunidades, totalizando aproximadamente 20 mil habitantes (IBGE, 2011). Dentre as principais comunidades, destacam-se as vilas de Piraquara e Curuai, sendo essa última a mais importante, cuja organização aproxima-se de características urbanas. A vila de Curuai é a porta de entrada da região e centro de referência por seus serviços e comércio. Entretanto, a exemplo das demais vilas da região, a vila de Curuai tem infraestrutura precária em termos de atendimento à saúde, transportes, eletricidade (é fornecida por geradores da mineradora ALCOA, de Juruti) e telecomunicações (não há rede de telefone fixo, internet ou telefonia móvel). Inserido no contexto da região de terra firme, encontra-se o Projeto de Assentamento Agroextrativista (PAE) Lago Grande (Figura 7), criado pela Portaria INCRA/SR30/ n 31 de 2005, com uma área de 2.503,44 km², onde são desenvolvidas atividades de pecuária e agricultura, organizadas em torno de diversas vilas existentes na região.

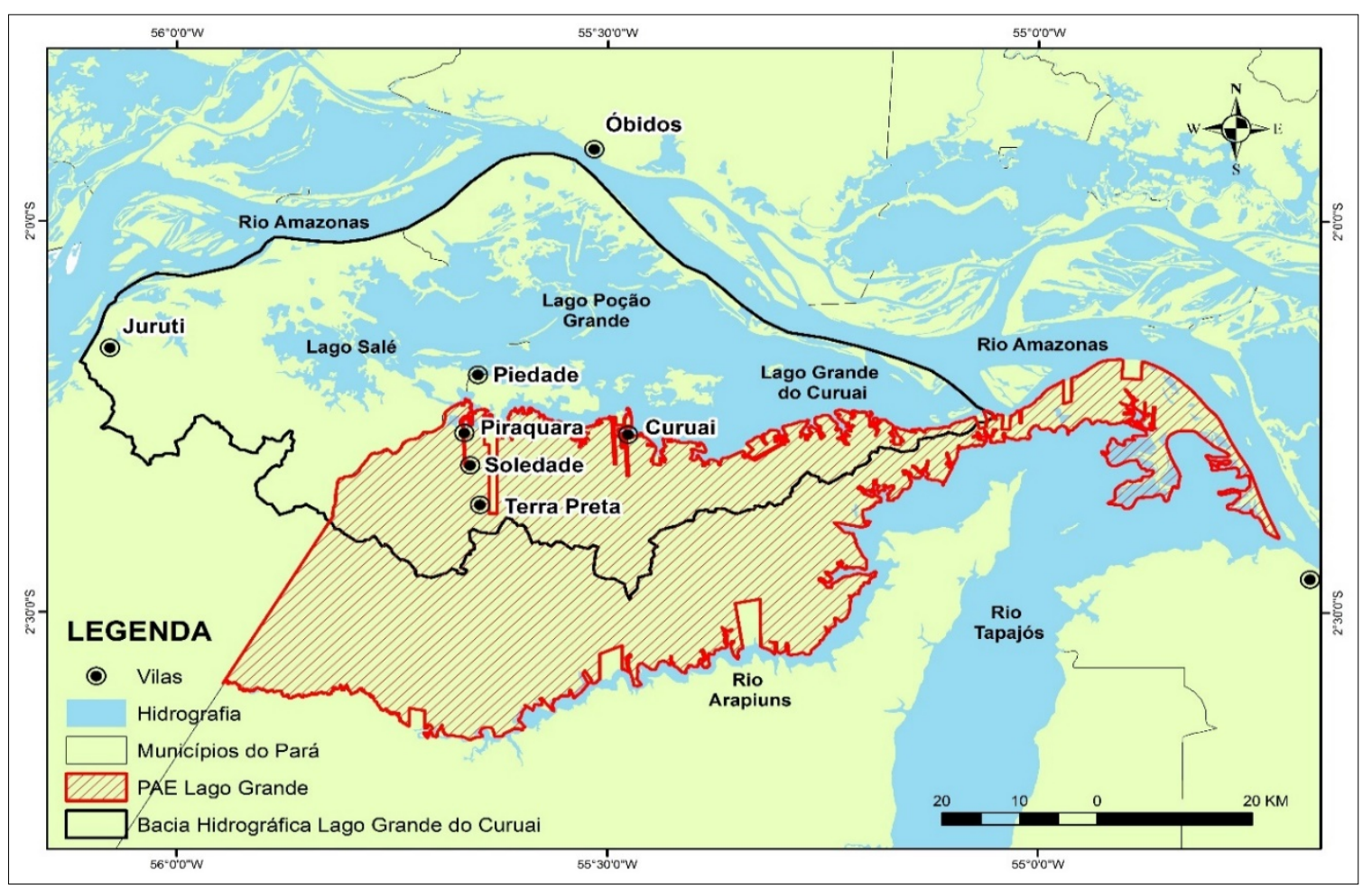

Figura 7: Localização do PAE Lago Grande. Fonte: elaborado pelo autor.

O ritmo da vida na região segue a variação do nível da água, e os seus habitantes estão sujeitos aos alagamentos anuais, que podem cobrir suas plantações e suas casas (Figura 8). O “calendário das águas” na região pode ser dividido em quatro períodos: enchente (meses de dezembro a fevereiro), cheia (de março a junho), vazante (julho a agosto) e seca (setembro a novembro) (Figura 9). Em terra firme, a agricultura de subsistência itinerante - onde se 
destaca a produção de farinha de mandioca (Figura 10) - e a pecuária imperam. Nas áreas de várzea, as inundações contribuem com a fertilização e aporte de nutrientes ao solo. Durante o período das cheias, a atividade pecuária se concentra basicamente em terra firme, o que se inverte na época das águas baixas, devido ao rebaixamento do nível da água que faz emergir pastos naturais, formados basicamente de herbáceas e arbustos de grande valor nutritivo para o gado (Figura 11). A atividade pesqueira também exerce grande importância econômica na várzea.

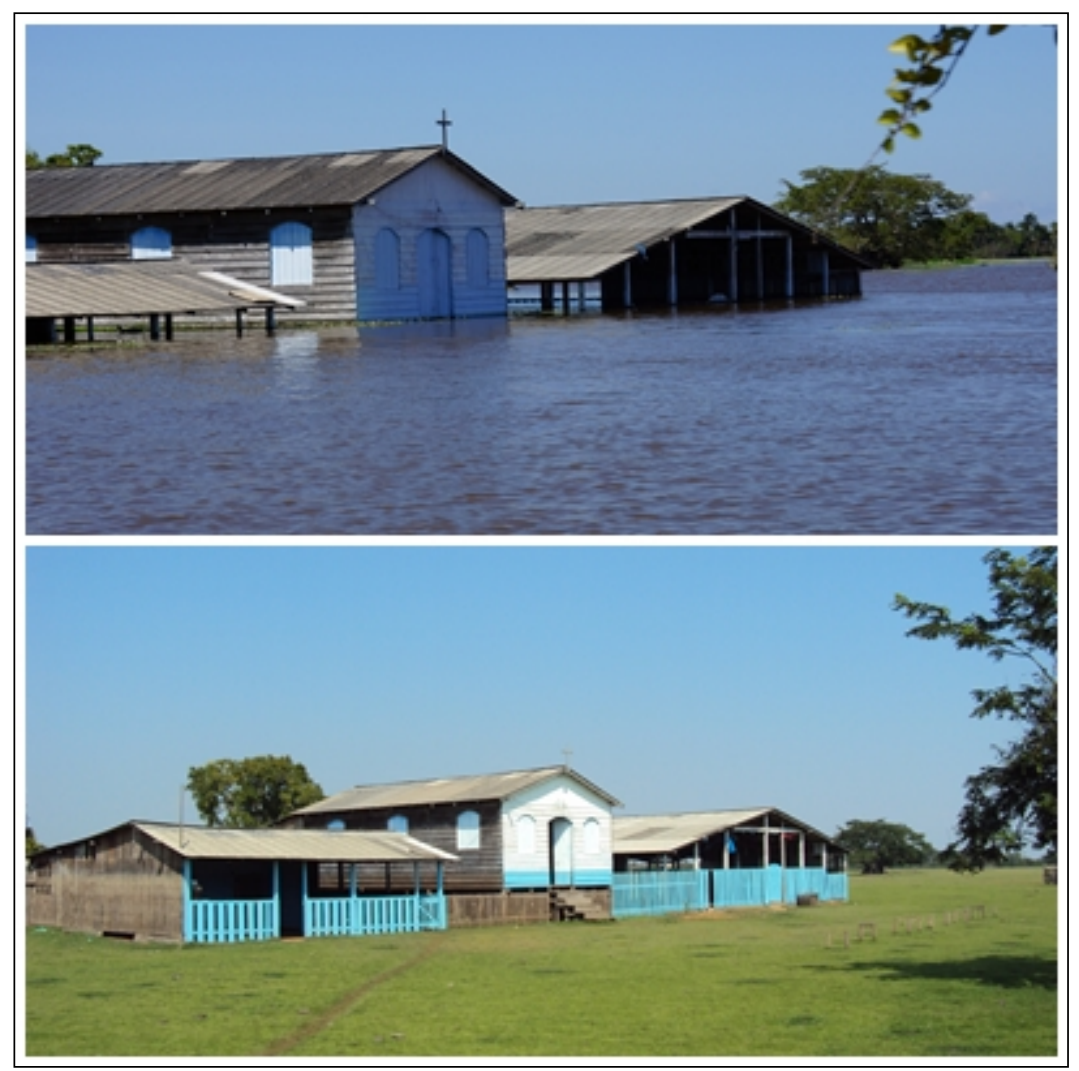

Figura 9: Inundação na Vila do Torrão do Papa Terra, região do Lago Grande do Curuai. Acima, imagem de maio de 2014, período da cheia; abaixo, imagem de novembro de 2014, período de seca. Fonte: elaborado pelo autor.

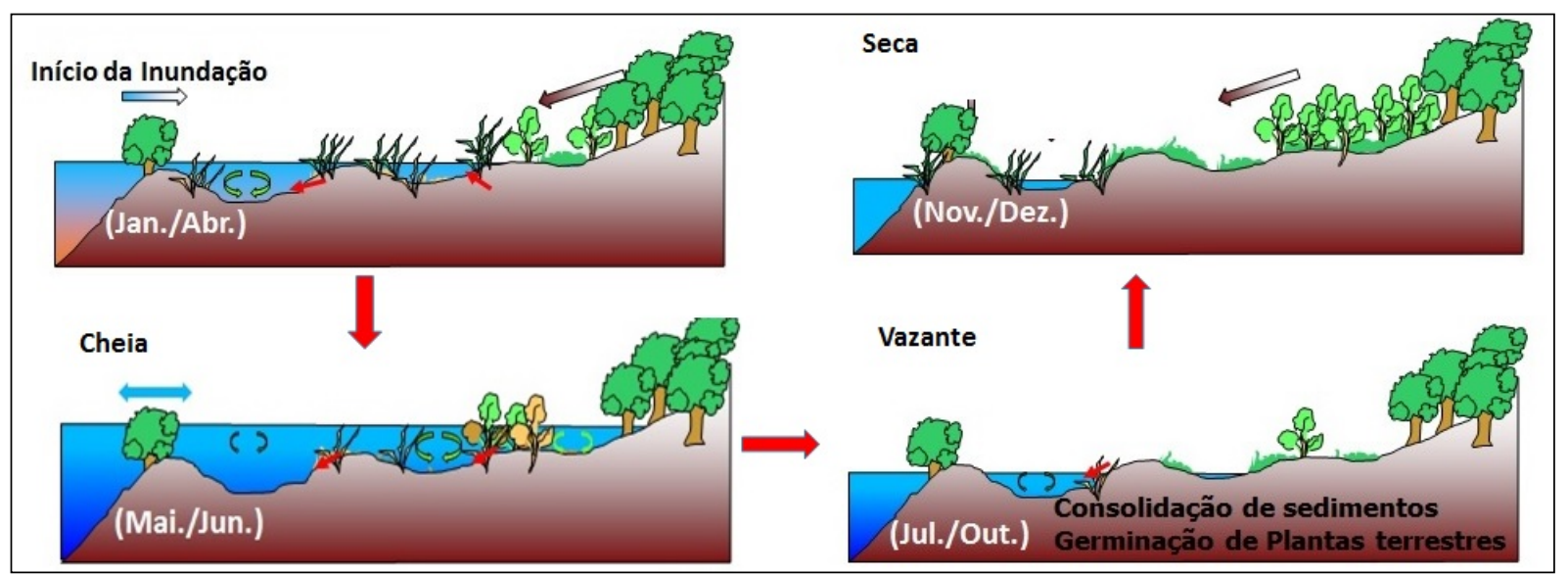

Figura 8: Esquematização do ciclo de inundação nas planícies amazônicas Fonte: adaptado de Junk (1984). 


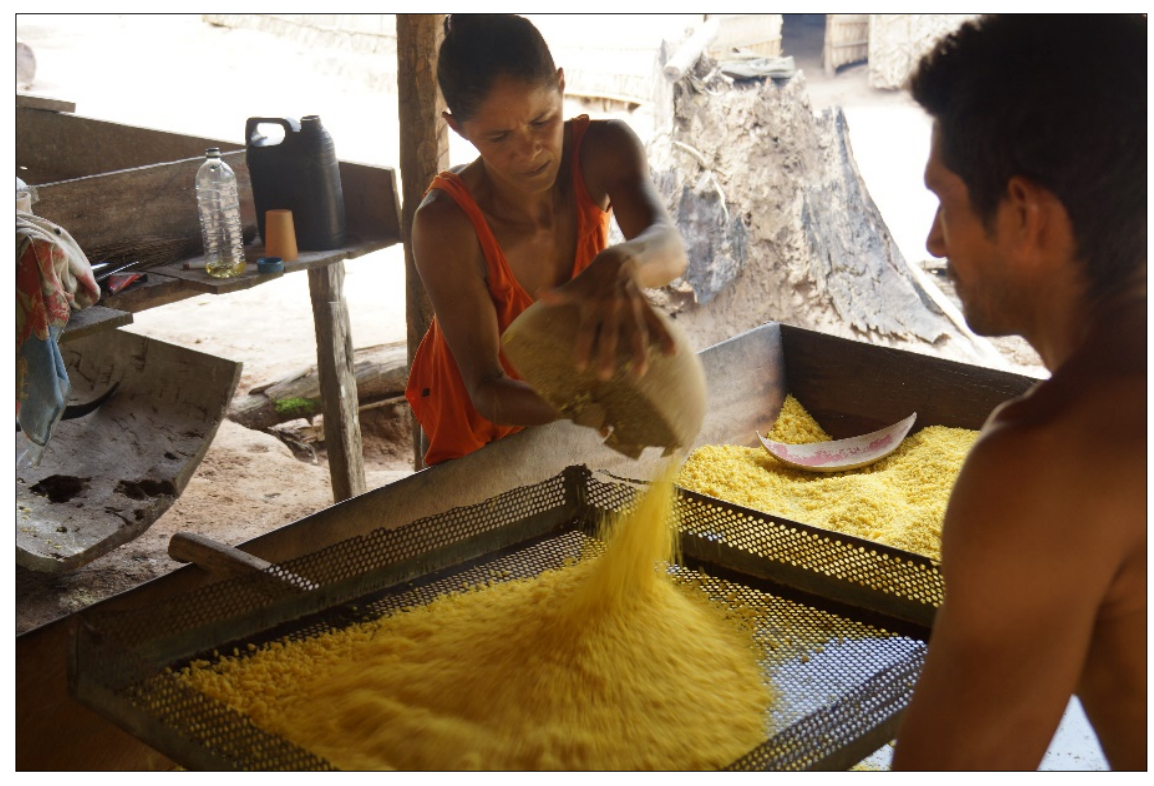

Figura 10: Produção de Farinha de Mandioca nas proximidades da Vila de Piraquara, maio de 2014. Fonte: elaborado pelo autor

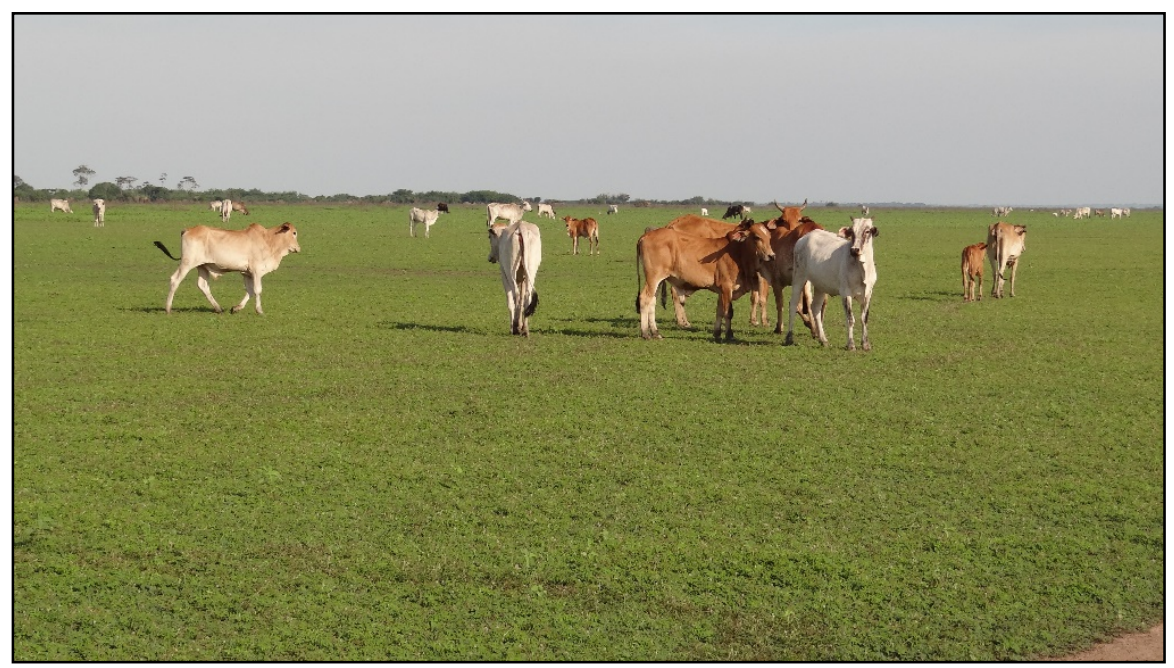

Figura 11: Pecuária sendo praticada na região da várzea durante a seca (novembro de 2014). Fonte: elaborado pelo autor.

\subsubsection{HISTÓRICO DE USO E OCUPAÇÃO}

O processo de ocupação do Bioma Amazônia ocorreu de maneira díspar, devido a fatores históricos e geográficos. O mesmo teria sido iniciado há 14 mil anos por sociedades indígenas complexas e diversas, que se ajustavam tanto aos ambientes de várzea das planícies alagadas como as florestas de terra firme (IMAZON, 2014). Inserida no contexto das grandes navegações, a colonização da Amazônia pelos europeus - mais destacadamente espanhóis e 
portugueses - concentrou-se no domínio das populações indígenas e na ocupação às margens dos rios (IMAZON, 2014).

Essa ocupação do território concentrou as atividades econômicas basicamente em coleta de recursos e pesca. Esse quadro só foi alterado pelo primeiro grande boom econômico da região, o chamado “ciclo da borracha”, durante a segunda metade do século XIX. O ciclo da borracha teve seu declínio a partir do plantio de seringueiras no sudoeste asiático e no desenvolvimento do uso da borracha a partir de derivados do petróleo. Após a crise da borracha, a região mergulhou novamente num período de extrativismo e agricultura de subsistência, um quadro de estagnação econômica alterado somente a partir da segunda metade do século XX (Teixeira, 1998).

A partir de 1964, início do governo militar, os planos de integração nacional e os megaprojetos de desenvolvimento marcaram o início de uma nova fase de ocupação e de mudanças econômicas na região. Conforme Becker (1982), a visão dos militares e do governo central era de que a Amazônia deveria ser ocupada e explorada, reafirmando a soberania nacional sobre a região e contribuindo para o crescimento econômico do país. Dessa maneira, foram criados diversos projetos baseados na distribuição de terras, na exploração mineral e vegetal e na colonização do território. Assim, o Brasil se voltou para essa enorme parcela do seu território, intensificando seu processo de ocupação.

As grandes marcas desse período foram a abertura de estradas, como a Belém-Brasília e a Transamazônica, o início do aproveitamento hidrelétrico da região a partir de usinas como Tucuruí e Balbina, além da exploração dos recursos minerais, cujo maior exemplo é o projeto Carajás, no Pará. Além disso, houve farta distribuição de terras em projetos de assentamentos e de criação de bovinos. Esse período marca o início das maiores alterações do quadro natural do bioma, provocadas principalmente pela abertura de estradas e pela colonização.

Isto posto, podemos dividir a ocupação do Bioma Amazônia em dois grandes períodos: o primeiro ciclo de ocupação, feito ao longo dos rios e das várzeas, que perdurou durante toda a colonização portuguesa, incluindo o ciclo da borracha, até a primeira metade do século XX; e um segundo grande ciclo, com a ocupação a partir das estradas, sobretudo em terra firme, por meio do projeto modernizador-autoritário de ocupação do território promovido pelos governos militares, a partir da segunda metade do século XX (Teixeira, 1998).

Em relação a bacia hidrográfica do Lago Grande do Curuai, no contexto do primeiro ciclo de ocupação, destaca-se a atividade pecuária na região das várzeas próximas a Santarém 
que teve início em 1661, com o estabelecimento de uma missão comandada por europeus (Bunker, 1982). Esse sistema de criação de gado era extensivo e fazia uso das gramíneas da várzea quando o nível da água estava baixo, em época de seca, e deslocava o gado para regiões mais altas em terra firme, na época de cheia (Bunker, 1982). Segundo Folhes (1997), atualmente a pesca e a pecuária são as atividades mais importantes economicamente, sendo, junto com a agricultura de subsistência e o extrativismo, os principais usos estabelecidos na região do Lago Grande do Curuai.

Já em conexão ao segundo grande ciclo de ocupação, o mesmo trouxe infraestruturas e projetos para as proximidades da região de estudo, destacando-se a BR-163 e grandes atividades mineradoras. A BR-163 parte da cidade de Cuiabá, no Mato Grosso, e percorre aproximadamente 1300 quilômetros em direção ao norte, atravessando o oeste do estado do Pará, até a cidade de Santarém. Ao longo do trecho paraense encontra-se um dos maiores focos de desmatamento do Brasil ${ }^{2}$. A BR-163 é uma importante via de escoamento da produção de grãos de Mato Grosso, sendo parte dessa produção embarcada no porto de Santarém, com destino a mercados consumidores estrangeiros. A rodovia encontra-se atualmente pavimentada, e conta inclusive com um projeto de implantação de uma ferrovia paralela a estrada ${ }^{3}$. Quanto a extração de recursos mineiras, a mineradora americana Alcoa lidera a extração de bauxita em Oriximiná, ao norte da região de estudo, e em Juruti, ao sul da região de estudo ${ }^{4}$. Essas pressões externas, além da presença do assentamento PAE Lago Grande, podem aumentar as dinâmicas de conversão da cobertura vegetal natural em usos antrópicos.

Os quase três séculos de ocupação da bacia hidrográfica do Lago Grande do Curuai e os 14 mil anos de presença humana no Bioma Amazônia tem como sua maior marca a substituição de cobertura vegetal natural por usos antrópicos. Entretanto esse processo ocorreu de maneira heterogênea no tempo e no espaço. Segundo o IMAZON (2014), até 1975, apenas 1\% da área do Bioma Amazônia em território brasileiro havia sido alterada. Todavia, nas últimas quatro décadas, o desflorestamento já alcançou aproximadamente $18 \%$ da área brasileira do Bioma Amazônia (INPE, 2015).

\footnotetext{
${ }^{2}$ Fonte:http://www.ihu.unisinos.br/noticias/512667-desmatamento-dispara-na-regiao-da-br-163

${ }^{3}$ Fonte:http://g1.globo.com/pa/para/noticia/2015/06/governo-anuncia-que-estrada-portos-e-ferrovias-do-paravao-leilao.html; $\quad$ http://www.canalrural.com.br/noticias/rural-noticias/ministro-dos-transportes-afirma-queasfaltamento-br-163-sera-finalizado-2016-54484

${ }^{4}$ Fonte: http://www.usp.br/mudarfuturo/cms/?p=385; http://www.oeco.org.br/foto-do-leitor/21645-mineracaoem-porto-trombetas/
} 
Com uso de sensoriamento remoto, é possível realizar o monitoramento do desmatamento e a identificação temporal das mudanças de uso e cobertura do solo. Conforme Renó (2010), o advento dos satélites de monitoramento de recursos naturais, notadamente os da série Landsat, permitiu estabelecer o levantamento do estado da cobertura vegetal no Bioma Amazônia.

\subsubsection{GEOTECNOLOGIAS E MONITORAMENTO DE MUDANÇAS DE USO E COBERTURA DA TERRA}

O sensoriamento remoto é uma das principais ferramentas para detecção de mudanças de uso e ocupação da terra, por permitir uma tomada grande de dados para análise em frações consideráveis do território. Segundo Kiel (2008), para que mudanças sejam detectadas, é necessário comparar imagens de satélite de um mesmo local adquiridas em períodos diferentes. Dessa forma, é possível identificar, a partir da assinatura espectral dos alvos, o que foi alterado e a quantidade dessa alteração. Dentre os satélites com aplicações desse tipo de monitoramento, destacam-se os da série Landsat.

A série Landsat teve início na segunda metade da década de 60, a partir de um projeto desenvolvido pela Agência Espacial Americana e dedicado exclusivamente à observação dos recursos naturais terrestres. Essa missão foi denominada Earth Resources Technology Satellite (ERTS) e em 1975 passou a se chamar Landsat. A missão é gerenciada pela National Aeronautics and Space Administration (NASA) e pela United States Geological Survey (USGS) e envolveu até o momento o lançamento de oito satélites. Nesse trabalho, foram utilizadas imagens dos anos de 1985, 1997 e 2014, oriundas dos satélites Landsat 5 e Landsat 7, que utilizam os sensores TM e ETM+, respectivamente.

O sensor TM foi lançado a bordo dos satélites Landsat 4 e Landsat 5 e operou nesse último desde seu lançamento, em 1984, até o ano de 2012. Possui 7 bandas espectrais nas regiões do visível, infravermelho próximo, médio e termal. Sua resolução espacial é de 30 metros, com resolução radiométrica de 8 bits, imageando uma área de 185 km² a cada 16 dias. O sensor ETM+, a bordo do satélite Landsat 7, foi o sucessor operacional do instrumento TM e manteve configurações técnicas muito semelhantes a ele, como as resoluções espacial, temporal e radiométrica. Em 31/05/2003 o sensor apresentou problemas de funcionamento. A partir dessa data as cenas do Landsat 7 foram disponibilizadas em modo SLC-Off. Para serem utilizadas nesse estudo, foram feitas correções prévias e análise de acurácia no posicionamento e calibração dos pixels. 
Inúmeros trabalhos foram desenvolvidos no bioma Amazônia, elaborados nas esferas acadêmica e governamental, com foco na análise de mudanças de uso e cobertura da terra. Escada (2003) realizou um trabalho na região centro-norte de Rondônia, utilizando imagens dos satélites Landsat do ano de 1985 até 2000, produzindo uma série de dados demonstrando uma triplicação no desmatamento na região durante o período analisado. Miranda (2011) fez uso de imagens Landsat 5 na identificação do desmatamento em uma área de unidade de conservação no estado do Amazonas, entre os anos de 1999 e 2008. Lopes (2008), também utilizando imagens Landsat, identificou um aumento do desmatamento no município de Tailândia, no estado do Pará; Vasconcelos e Novo (2005) similarmente utilizaram imagens Landsat na identificação de alterações de uso e cobertura da terra ao redor do lago de Tucuruí, no Pará, e constataram um aumento das áreas desmatadas e convertidas em pastagens.

Souza (2012) igualmente utilizou imagens Landsat na identificação de mudanças espaço-temporais na paisagem na bacia do rio Peixe-Boi, no estado do Pará, constatando um aumento da pressão antrópica na região pelas atividades agropecuárias. Nas regiões de várzea, destacam-se os trabalhos de Renó (2010), que analisou, utilizando imagens Landsat, toda a região de várzea do rio Amazonas a jusante da cidade de Manaus, entre os anos de 1975 e 2008, identificando uma diminuição das florestas naturais na área estudada. Hess (2003) utilizou imagens de radar na análise das áreas inundáveis próxima a Manaus, identificando diferenças nas regiões a montante a jusante da capital amazonense. O projeto PRÓ-VÁRZEA (IBAMA, 2005) produziu um grande levantamento acerca das condições socioeconômicas das populações ribeirinhas da calha dos rios Solimões e Amazonas.

Kiel (2008) aponta que há diversos projetos baseados na detecção de mudanças no uso e na cobertura do solo, em sua grande maioria utilizando dados oriundos de sensoriamento remoto orbital, exemplificando a aplicação dessa tecnologia nesse tipo de estudo. Entre esses projetos, destacam-se o PRODES e o TerraClass, ambos desenvolvidos pelo INPE. Entretanto, devido a fatores de ordem metodológica e de limitações técnicas e operacionais, esses programas concentram seus esforços na análise das áreas de fitofisionomia florestal em terra firme.

Esses projetos são orientados, em sua maior parte, para a identificação qualitativa e quantitativa das mudanças, como forma de estabelecer pontos comparativos de uso e cobertura da terra ao longo dos anos. A análise das formas de ocupação de uma parcela do espaço pode levar em conta inúmeros fatores, sendo um dos mais estudados a paisagem. 
Mattos (2003) aponta que a paisagem possui caráter temporal e dinâmico, podendo assim, com o passar dos anos, sofrer alterações em seus elementos.

\subsubsection{MÉTRICAS DE PAISAGEM}

Semelhante a praticamente todos os termos e conceitos do escopo da Geografia, o conceito de paisagem não está isento de controvérsias e de uma definição única que abarque suas diversas facetas. Segundo Souza (2013), a definição de paisagem é tão abrangente que de certo modo torna-se sinônimo de “espaço geográfico” e de “área”. Entretanto, a paisagem tem na Geografia um sentido relacionado ao "espaço abarcado pela visão de um observador" (Forman \& Godron, 1986). Esse espaço seria, todavia, limitado por aspectos que tornem a paisagem homogênea e distinta de outros espaços que possam ser observados. Assim, pode-se definir a paisagem como uma área composta de elementos que lhe deem certa homogeneidade, repetindo-se de modo similar por sua extensão, sendo distinta das áreas heterogêneas que a circundem.

Segundo Silva (1998), as paisagens se dividem em dois grupos: as paisagens naturais, as quais não foram submetidas a ação antrópica, sendo resultante dos fatores naturais (tais como clima, solos e organismos); e as paisagens modificadas, aquelas que são alteradas e transformadas pela ação humana. Um dos mais importantes campos de estudos da paisagem é denominado de ecologia de paisagens. A ecologia de paisagens envolve o estudo de padrões da paisagem, as interações entre os fragmentos dentro de um mosaico da paisagem e de como estes padrões se modificam com o decorrer do tempo.

Segundo Forman \& Godron (1986), a ecologia de paisagens busca compreender as relações estabelecidas entre a estrutura, a função, e a dinâmica dos ecossistemas, os quais são interativos e característicos de uma determinada região. Metzger (2001) aponta que há duas abordagens principais dentro da ecologia de paisagens: uma geográfica, que estuda a influência do homem em uma determinada paisagem e na gestão territorial, considerando a relação homem-meio como primordial para a construção e alteração das paisagens; e outra ecológica, que enfatiza a importância do contexto espacial sobre os processos ecológicos juntamente com sua importância em relação à conservação da biodiversidade.

O presente trabalho busca utilizar a abordagem geográfica. Dessa forma, o foco da ecologia de paisagens, na abordagem geográfica, se concentraria na relação entre o homem e a paisagem, e na forma pela qual este a modifica. Metzger analisa que: 
A ecologia de paisagens pode contribuir para estudos ambientais, pois se propõe a lidar com mosaicos antropizados, na escala na qual o homem está modificando o seu ambiente. Na "abordagem geográfica” (em especial), mais do que uma análise detalhada de impactos locais (principal enfoque da ecologia de ecossistemas e de comunidades), a ecologia de paisagens procura entender as modificações estruturais (portanto funcionais), trazidas pelo homem no mosaico como um todo, incorporando de forma explícita toda a complexidade das inter-relações espaciais de seus componentes, tanto naturais quanto culturais (METZGER, 2001, p.7).

Os principais elementos da paisagem são: fragmento, corredor e matriz. Metzger (2001) aponta que um fragmento é uma mancha originada por fragmentação, sendo uma subdivisão promovida pelo homem de uma unidade que inicialmente apresentava-se de forma contínua. Já a matriz é a unidade que controla a dinâmica da paisagem, em geral recobrindo a maior parte da paisagem (Metzger, 2001).

A ecologia de paisagens torna-se uma ciência importante para a mensuração de mudanças na paisagem, pois oferece um conjunto de métricas que possibilitam caracterizar, no espaço e no tempo, os padrões de uso e cobertura da terra (Turner e Carpenter, 1998). No domínio dessa ciência, a mensuração desses padrões se dá por meio de métricas e índices. Pirovani (et al, 2012) apontam que os índices utilizados em ecologia da paisagem representam ferramentas para a quantificação dos padrões espaciais e posterior comparação entre as paisagens. Os aspectos abordados por Pirovani (et al, 2012) permitem a identificação, no âmbito das paisagens, de suas alterações ou mudanças de forma temporal.

No âmbito da ecologia de paisagens, existe uma enorme variedade de índices e métricas, agrupados em diversos softwares. Para a avaliação de métricas da paisagem, a ferramenta mais utilizada é o software chamado Fragstats, desenvolvido por MacGarigal e Marks (1995). Neste trabalho, foi utilizada a extensão para o ArcGIS chamada Patch Analyst, que apresenta métricas semelhantes as utilizadas pelo Fragstats, porem sintetizadas. Essas métricas estão relacionadas à área, a borda, à forma, e por último, ao tamanho e a variabilidade, sintetizando os parâmetros para a caracterização espacial de um fragmento. As métricas apresentam-se na Tabela 1.

Tabela 1: Exemplos de Métricas da Paisagem disponíveis nos programas Fragstats e Patch Analyst. Fonte: adaptado de McGarigal and Marks (1995)

\begin{tabular}{|c|l|}
\hline Métricas utilizadas pelo Patch Analyst 5.0 & Siglas e principais definições \\
\hline Métricas de Área & $\begin{array}{l}\text { CA - Área da Classe TLA - Área Total da } \\
\text { Paisagem }\end{array}$ \\
\hline Métricas de Borda & $\begin{array}{l}\text { TE - Borda Total ED - Densidade da Borda } \\
\text { MPE - Média de Borda do Fragmento }\end{array}$ \\
\hline
\end{tabular}




\begin{tabular}{|c|l|}
\hline \multirow{4}{*}{ Métricas de Forma } & $\begin{array}{l}\text { MSI - Índice de Forma Média AWMSI - } \\
\text { Índice de Forma Média Ponderada pela Área } \\
\text { (Fragmentos maiores recebem maior peso) } \\
\text { MPFD - Dimensão Fractal do Fragmento } \\
\text { Médio (variação entre 1 e 2; valores mais } \\
\text { próximos de 2 apresentam uma maior } \\
\text { complexidade no fragmento) AWMPFD - } \\
\text { Dimensão Fractal de Fragmento Médio } \\
\text { Ponderado pela Área MPAR - Média de } \\
\text { Proporção Perímetro-Área }\end{array}$ \\
\hline \multirow{5}{*}{ Métricas de Tamanho e Variabilidade } & $\begin{array}{l}\text { MEDPS - Tamanho Mediano do Fragmento } \\
\text { NumP - Número de Fragmentos MPS - } \\
\text { Tamanho Médio dos Fragmentos PSSD - } \\
\text { Desvio Padrão do Tamanho dos Fragmentos } \\
\text { (variação absoluta) PSCoV - Coeficiente de } \\
\text { Variação do Tamanho dos Fragmentos } \\
\text { (variação relativa) }\end{array}$ \\
\hline
\end{tabular}

Diversos trabalhos foram desenvolvidos utilizando-se métricas e índices de paisagem em análises espaço-temporais de dinâmicas de uso e cobertura da terra, em vários biomas brasileiros. Pinheiro (2012) utilizou uma série temporal de imagens Landsat entre os anos de 1998 e 2008 e aplicação de métricas de paisagem, no município de Correntina-BA, de forma a analisar um aumento da fragmentação da paisagem devido a implantação de agronegócio, observando uma redução do tamanho médio dos remanescentes de cerrado durante o período estudado. Chaves (2015) utilizou métricas de paisagem em classificação resultante de imagens PRISM/ALOS no município de Céu Azul-PR, identificando que a fragmentação na região diminuiu devido ao cumprimento da lei de áreas de preservação permanente.

Lima (2011) utilizou métricas de paisagens para analisar a fragmentação florestal do município de Juiz de Fora-MG entre 1987 e 2008, identificando um elevado grau de fragmentação na região e que se acentuou nas datas mais recentes. Rudolpho (2013) também empregou métricas de paisagem em uma análise temporal da cobertura florestal da cidade de Blumenau-SC, detectando uma diminuição das áreas de remascentes florestais; Saito (2011) utilizou dados do PRODES de diferentes regiões do Bioma Amazônia e aplicou de métricas de paisagem, de forma a determinar padrões de desmatamento e diferentes tipos de ocupação humana; Peres (2014) empregou cálculos de métricas de paisagens em dados oriundos do TerraClass para o ano de 2008, em áreas da fronteira Brasil-Guiana Francesa no Amapá, identificando um baixo grau de fragmentação da paisagem devido a existência de áreas protegidas na região;

O fenômeno das mudanças de uso e cobertura da terra pode ser observado no bioma Amazônia em diversas escalas e intensidades, sendo influenciado por diferentes fatores. A 
complexidade desse fenômeno pode ser estudada através de distintos recortes geográficos, de forma a proporcionar um melhor entendimento do problema. Mudando-se o recorte de análise das alterações de uso e cobertura da terra, podemos identificar dinâmicas diferentes, o que serve para demonstrar a heterogeneidade das formas de uso e ocupação e como as mesmas se dispõem dentro do próprio bioma.

\subsubsection{RECORTES GEOGRÁFICOS}

Dentro de uma abordagem geográfica, recortes geográficos podem representar os níveis de detalhe e de observação de um fenômeno. Conforme Lima (2005), a delimitação de um espaço possuidor de atributos próprios sempre esteve no escopo da Geografia. O recorte é fundamental em pesquisas de cunho geográfico e ambiental, pois permite compreender a atuação de um fenômeno sobre o espaço. Dentro de um contexto de análise espaço-temporal, o recorte torna-se importante pois pode ser indicativo de dinâmicas particulares, explanando seus períodos de ocorrência e atuação.

Em uma perspectiva de análise de detalhe, um recorte geográfico pode servir para demonstrar a heterogeneidade e a complexidade de um fenômeno, pois uma alteração em seu nível de análise leva a uma nova compreensão dos fenômenos. Em um bioma de dimensões continentais, fruto de um contexto histórico e natural ímpar, as alterações de uso e cobertura da terra apresentam-se de maneira heterogênea. Uma modificação no recorte geográfico de análise de um fenômeno seria capaz de produzir uma nova compreensão sobre o mesmo. Dessa forma, ao utilizar recortes geográficos diversos para uma mesma área de estudo, é possível identificar distintas dinâmicas, fatores e consequências.

Entre os trabalhos desenvolvidos no Bioma Amazônia e que se utilizaram deste artifício, destacam-se os estudos feitos por Laques (1993) e Escada (2003). Laques (1993) produziu um estudo na floresta de Ticoporo, na Venezuela, com o objetivo de obter uma visão

global da frente pioneira de ocupação da região, para o gerenciamento da ocupação e tomada de decisões. Para isso, estruturou a metodologia em duas etapas, sendo que a primeira se constituiu de aquisição de conhecimento sobre a região de estudo, onde se identificou os agentes modificadores da paisagem - dentro de uma abordagem ambiental e econômica - e a dinâmica espaço-temporal. Em um segundo momento foi elaborada uma carta-síntese das 
zonas de desflorestamento, levando a delimitação de áreas distintas, identificando processos e estruturas dominantes na paisagem e cenários futuros de evolução espacial.

Escada (2003) realizou um trabalho no nordeste de Rondônia, propondo uma partição do espaço estudado, compartimentando a região em Unidades de Ocupação, que apresentavam padrões espaciais observáveis, a partir de uma série Landsat de 1985 a 2000 . A metodologia aplicada identificou, por meio de imagens de satélites, diferentes configurações espaciais que foram individualizadas. A hipótese do trabalho era a de que as distintas Unidades de Ocupação apresentavam diferentes dinâmicas observáveis a partir das imagens de satélite. Foram definidas 54 unidades correspondendo a assentamentos rurais e fazendas, 06 áreas correspondentes a núcleos urbanos e 16 áreas correspondentes a reservas florestais. A divisão em Unidades de Ocupação permitiu verificar que o desmatamento ocorreu de forma diferenciada nos assentamentos rurais e que a área de ocupação mais antiga era a mais desmatada.

O presente trabalho propõe-se utilizar de dois recortes geográficos sobre a mesma área de estudo: um primeiro, que corresponde a toda a bacia hidrográfica do Lago Grande do Curuai; e um segundo recorte, composto por uma divisão da bacia hidrográfica em seis zonas de paisagem. Com o uso desses recortes, espera-se aprofundar o detalhamento da identificação e análise das dinâmicas espaço-temporais de uso e cobertura da terra. Lima (2005) afirma que um recorte de estudo com limites naturais, como a bacia hidrográfica, permite a real identificação espacial de processos relacionados. Nesse recorte, os elementos naturais, como os fluxos de energia, sedimento e água encontram-se dentro de certos limites, correlacionando-se a outros elementos, como os solos e a vegetação. Segundo Lima (2005), a sociedade pode ser vista como agente de interferência nesses processos naturais, estando seus fluxos no mesmo nível dos fluxos gerados por elementos naturais. Esse recorte tem como objetivo analisar o comportamento da vegetação natural (expressa pela floresta de terra firme e de várzea) na área de estudo. O segundo recorte, das zonas de paisagem, delimitou a bacia em seis zonas de paisagem (Figura 12).

Os critérios para a definição dessas zonas foram embasados a partir das metodologias empregadas por diversos autores (Beringuer et al, 1997; Deffontaines, 1985; Lizet e Ravignan, 1987). Essa atividade envolve basicamente o trabalho de campo, o contato com os atores (moradores e lideranças) locais e a análise de imagens de satélite. A primeira etapa (trabalho de campo) envolve um estudo e contextualização prévia da região a ser estudada, 
através de revisão bibliográfica que indique o histórico de ocupação e as atividades econômicas praticadas na região. Também nessa etapa são analisados limites administrativos que podem influir na delimitação das zonas de paisagem, tais como limites municipais, estaduais e de áreas especiais (como assentamentos rurais, terras indígenas e unidades de conservação). Posteriormente, é realizada uma visita prévia ao local de campo, onde são identificados os atores (principalmente agricultores), analisando o funcionamento da zona e seu uso pelos mesmos. Se possível, é fundamental percorrer toda a zona, de forma a identificar na paisagem elementos heterogêneos entre si, construindo as tipologias de uso e associando-as aos atores. Assim, estabelece-se previamente alguns limites dentro do que já foi observado.

A partir disso, com o auxílio de imagens de satélite, são estabelecidos limites que podem ser confrontados novamente, em um segundo trabalho de campo, com as impressões dos atores locais, de forma a confirmar com quem vive a realidade local se o que está estabelecido possui coerência com as formas de moldar o ambiente praticadas pelos mesmos. Se não for possível realizar trabalho de campo complementar, classificações de uso e cobertura da terra feitas no decorrer do processo podem facilitar a delimitação das áreas; os componentes e classes resultantes das classificações têm que estar consonantes com a delimitação das zonas. Nessa etapa, a fotointerpretação torna-se fundamental, pois permite correlacionar os limites com o resultado das classificações. A partir das delimitações é possível quantificar o percentual de cada zona em relação a paisagem completa e esquematizar uma organização do funcionamento da área de estudo. Por fim, a delimitação das zonas leva basicamente em conta a relação entre o homem e suas práticas e o meio ambiente.

Na região de estudo do presente trabalho, as zonas são correspondentes a uma correlação entre os sistemas de produção agropecuária da região e os aspectos naturais do ambiente. Esse limite foi definido a partir da associação entre os elementos presentes na bacia hidrográfica do Lago Grande do Curuai, sua localização geográfica e os usos que são estabelecidos pelos habitantes da região (Tabela 2 e Anexo L). Essa definição ocorreu após as observações de campo e análises de imagens de satélite. Esse recorte se justifica pois é possível analisar de forma independente como ocorrem as dinâmicas de uso e cobertura em áreas distintas dentro da bacia, permitido identificar áreas mais ou menos alteradas e facilitando a compreensão da ocupação. Além disso, permite detalhar e comparar mais 
satisfatoriamente as distintas paisagens da bacia. Também é possível identificar as dinâmicas dos próprios sistemas produtivos, avaliando sua evolução no tempo.

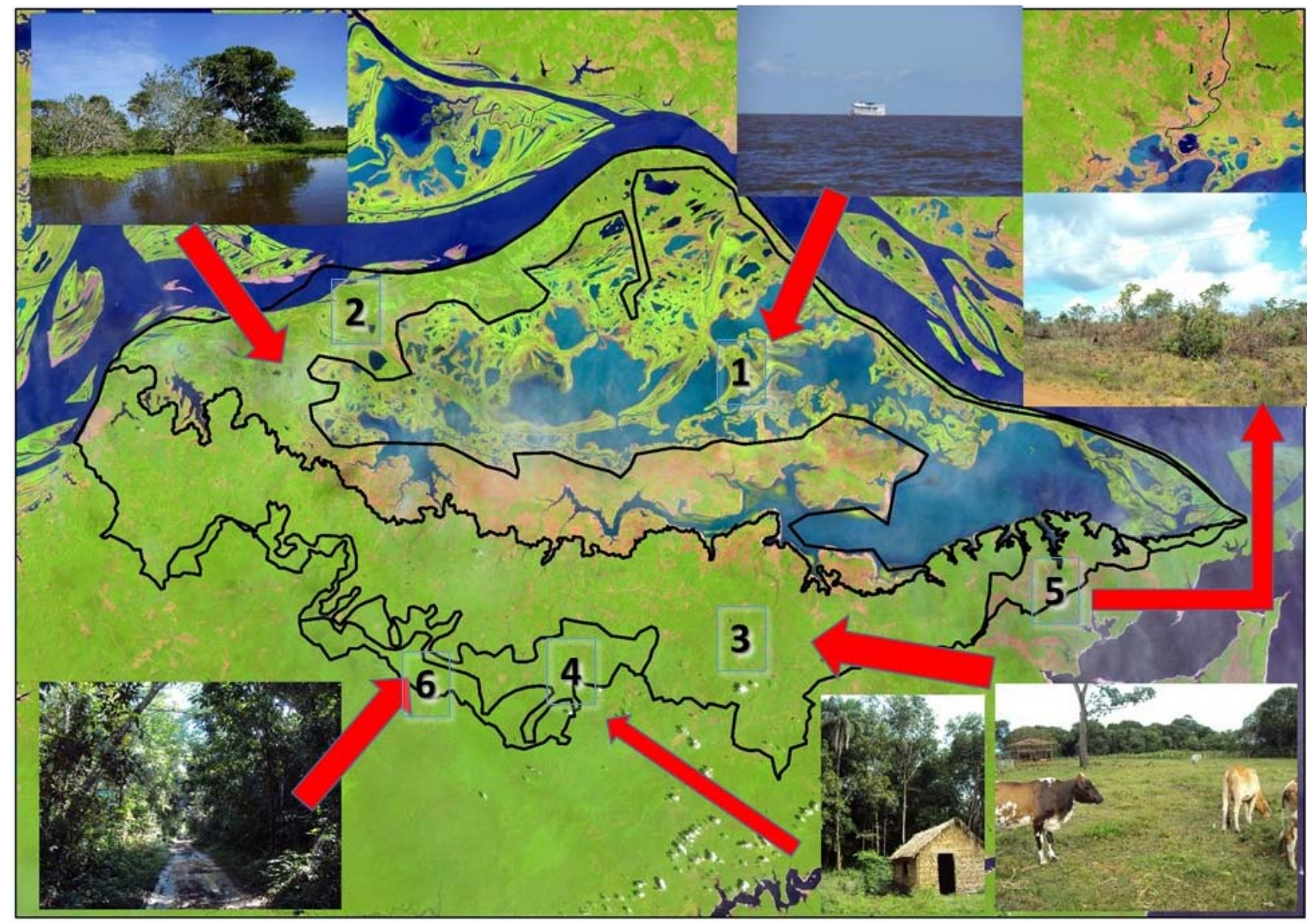

Figura 12: Zonas da Paisagem da Bacia Hidrográfica do Lago Grande do Curuai. Fonte: elaborado pelo autor. 
Tabela 2: Descrição das Características das Zonas da Paisagem (segundo recorte geográfico de estudo). Fonte: elaborado pelo autor.

\begin{tabular}{|c|c|c|}
\hline Número & Nome da Zona & Característica \\
\hline 1 & $\begin{array}{l}\text { Zona da paisagem do sistema } \\
\text { pastoral de várzea baixa }\end{array}$ & $\begin{array}{l}\text { Região mais baixa da várzea, permanece a maior parte } \\
\text { do tempo inundada }\end{array}$ \\
\hline 2 & $\begin{array}{l}\text { Zona da paisagem do sistema } \\
\text { pastoral de várzea alta }\end{array}$ & $\begin{array}{l}\text { Região mais alta da várzea, onde predominam os } \\
\text { arbustos e pastos naturais; alaga durante o pulso de } \\
\text { inundação do rio Amazonas }\end{array}$ \\
\hline 3 & $\begin{array}{l}\text { Zona da paisagem do sistema } \\
\text { agro-pastoral de terra firme }\end{array}$ & $\begin{array}{l}\text { Região onde predominam as atividades de agricultura e } \\
\text { pecuária, resultando em uma zona bastante alterada }\end{array}$ \\
\hline 4 & $\begin{array}{l}\text { Zona da paisagem do sistema } \\
\text { agro-florestal de terra firme }\end{array}$ & $\begin{array}{c}\text { Região onde ocorrem atividades antrópicas, mas a } \\
\text { floresta de terra firme ainda se mantém como principal } \\
\text { elemento }\end{array}$ \\
\hline 5 & $\begin{array}{l}\text { Zona da paisagem do } \\
\text { ecossistema de savana de } \\
\text { terra firme }\end{array}$ & Região de predominância de cerrados e savanas \\
\hline 6 & $\begin{array}{l}\text { Zona da paisagem do } \\
\text { ecossistema de floresta de } \\
\text { terra firme }\end{array}$ & $\begin{array}{c}\text { Região onde predomina floresta, com parca alteração } \\
\text { antrópica }\end{array}$ \\
\hline
\end{tabular}

A seguir, apresenta-se o capítulo 2, intitulado Análise da dinâmica das paisagens da bacia hidrográfica do Lago Grande do Curuai, Pará, com o detalhamento dos procedimentos metodológicos aplicados, além da apresentação dos resultados obtidos com a pesquisa e suas análises e discussões. Frisa-se que ele está no formato de um artigo científico, que será submetido ao periódico ACTA AMAZÔNICA (ISSN 0044-5967). 


\section{RESULTADOS}

\section{CAPÍTULO 2}

\section{ANÁLISE DA DINÂMICA DAS PAISAGENS DA BACIA HIDROGRÁFICA DO LAGO GRANDE DO CURUAI, PARÁ}

Capítulo elaborado e formatado conforme normas da revista Acta Amazônica (ISSN 0044-5967) 


\section{Análise da dinâmica das paisagens da bacia hidrográfica do Lago Grande do Curuai, Pará}

\section{Introdução}

Estendendo-se por aproximadamente 19\% da área do Bioma Amazônia (800 mil km² dos 4,2 milhões de km² de área total), as planícies de inundação da bacia Amazônica possuem importância ecológica e social elevada. O Amazonas é o principal rio do bioma, sendo acompanhado ao longo de seus cursos por planícies de inundação, que são compostas por dois ambientes: a várzea e a terra firme. As regiões de terra firme são as áreas não suscetíveis aos ritmos das cheias dos rios da região, segundo Rodrigues e Oliveira (1997). A várzea é a planície de inundação que oscila entre as fases terrestre e aquática (Alcântara et al, 2007). Conforme apontam Megonigal (et al, 1997), as várzeas apresentam-se como grandes centros de biodiversidade e biocomplexidade. Sendo o local de ocupação primária do bioma, ao longo das planícies de inundação do rio Amazonas e seus afluentes está o resultado do processo de ocupação tradicional da região, iniciado antes mesmo da colonização portuguesa.

O ritmo da vida na várzea segue a variação do nível da água, sendo seus habitantes submetidos às inundações anuais, que, alcançando valores de até 15 metros em algumas regiões da calha do rio Amazonas, podem cobrir suas plantações e casas. Essas inundações são fruto da variação sazonal no regime de chuvas nos afluentes e na própria cabeceira da bacia (Junk, 1984). As margens dos rios e as várzeas são ambientes frágeis, que concentram grande parte da população da região, e estão fortemente suscetíveis as variabilidades climáticas (IBAMA, 2005). Alterações no uso e cobertura da terra nas regiões de várzea, causadas principalmente pelas atividades agropecuárias, podem acarretar impactos na biodiversidade aquática (Costa et al., 2007) e na produção da pesca e na qualidade da água, afetando sobremaneira a população ribeirinha (Novo et al., 2007).

Dessa forma, torna-se fundamental compreender de que forma ocorre, no espaçotempo, o uso e a ocupação nesse tipo de ambiente. Estudos a respeito das dinâmicas temporais de uso e ocupação em várzeas amazônicas já foram desenvolvidos (Affonso, 2007; Hess, 2003; Renó; 2010), constatando diminuição na cobertura vegetal original das áreas de várzea. Entretanto, poucos estudos foram realizados utilizando recortes geográficos distintos, o que contribui para uma melhor compreensão da dinâmica socioambiental da região. Localizada próxima a cidade de Santarém, no estado do Pará, a região possui histórico de ocupação que data do século XVII e tem na pesca, pecuária e na agricultura de subsistência suas principais atividades econômicas. 
Representativa das várzeas do rio Amazonas, a bacia hidrográfica do Lago Grande do Curuai engloba os diversos lagos de sua planície de inundação, os igarapés que alimentam os lagos partindo da terra firme, e é submetida ao pulso sazonal do rio Amazonas (Bonnet et al, 2008). A região do Lago Grande do Curuai já foi foco de diversos estudos (Alcântara, 2007; Bonnet et al, 2008; Barbosa, 2005; Arraut, 2005; Trentin, 2009; Freitas, 2005); entretanto, seus esforços foram concentrados na análise hidrológica e pluviométrica dos lagos da região. Diante desse contexto, o objetivo desta pesquisa é analisar a dinâmica espaço-temporal de uso e cobertura da terra da bacia hidrográfica do Lago Grande do Curuai, utilizando técnicas de processamento de imagens oriundas de sensores orbitais e métricas de paisagens a partir de dois recortes geográficos distintos para a mesma área de estudo.

O primeiro recorte geográfico é referente a toda a bacia, com o propósito de identificar a dinâmica da cobertura vegetal natural representada pela floresta, de forma a reconhecer se este componente está estável, em crescimento ou em diminuição. O segundo recorte corresponde a seis zonas de paisagem, que foram determinadas utilizando metodologias que foram empregadas em trabalhos anteriores (Beringuer et al, 1997; Deffontaines, 1985; Lizet e Ravignan, 1987), metodologias essas que empregam uma análise de campo apoiada por imagens de satélites e que leva em conta principalmente a correlação entre o ambiente natural e os usos empregados pelo homem no ambiente. No presente estudo, esse recorte em seis zonas corresponde a uma divisão da bacia hidrográfica em áreas que possuem semelhança e correlação entre seus aspectos naturais e de uso, associando cada recorte a um sistema produtivo. O trabalho nesse recorte espacial foi realizado de forma a perceber se as alterações passíveis de detecção ocorrem de maneira heterogênea nas zonas de análise, identificando, dentre as seis zonas, quais seriam as mais dinâmicas e concentradoras das mudanças, e também monitorando as dinâmicas dos sistemas produtivos. Utilizar distintos recortes geográficos pode ser uma ferramenta relevante para compreender as peculiaridades de uso de uma determinada área e compreender como diferentes atividades antrópicas podem gerar diversos padrões espaço-temporais na paisagem, pois permite detalhar as alterações.

O sensoriamento remoto é uma das principais ferramentas para detecção de mudanças de uso e ocupação da terra, por permitir a aquisição de dados para análise em frações consideráveis do território. Devido ao grande volume de imagens atualmente disponíveis, é possível realizar análises temporais, permitindo conhecer de maneira mais relevante as dinâmicas terrestres. Dessa forma, para a identificação das dinâmicas foram classificadas imagens dos satélites Landsat 5 e Landsat 7, referentes aos anos de 1985, 1997 e 2014, 
correspondendo a quase 30 anos de análise, utilizando-se técnicas de classificação de imagens. Posteriormente, para identificação da estrutura dos padrões de uso e cobertura, foram aplicadas métricas de paisagens. As métricas de paisagem são medidas importante para a análise de mudanças na paisagem, pois possibilitam caracterizar, no espaço e no tempo, os padrões de uso e cobertura da terra (Turner e Carpenter, 1998).

Pirovani (et al, 2012) apontam que as métricas utilizadas em ecologia da paisagem representam métodos para a quantificação dos padrões espaciais e para a comparação entre paisagens, permitindo a identificação de suas principais mudanças ao longo do tempo. Dessa forma, este trabalho utilizou métricas de paisagem de forma a mensurar as dinâmicas de uso e cobertura dentro dos recortes geográficos de análise da área de estudo.

\section{Área de Estudo}

A bacia hidrográfica do Lago Grande do Curuai está localizada $850 \mathrm{~km}$ acima da foz do rio Amazonas, inserida nos municípios de Juruti (cuja sede municipal localiza-se dentro da bacia), Óbidos e Santarém, no estado do Pará (Figura 13). Sua extensão aproximada é de $3.807,54 \mathrm{~km}^{2}$. Os dois principais ambientes da bacia hidrográfica do Lago Grande do Curuai são a região de várzea, suscetível as inundações, e a terra firme. A alternância entre períodos de águas baixas e águas altas determina o calendário de atividades econômicas da região, sendo a pesca, a agricultura de subsistência e a pecuária as práticas mais importantes. No entorno do lago existem 147 comunidades, totalizando aproximadamente 20 mil habitantes (IBGE, 2011). Nas áreas de várzea, as inundações contribuem com a fertilização e aporte de nutrientes ao solo.

Durante o período da cheia, a atividade pecuária se concentra em terra firme. A lógica se inverte na época das águas baixas, devido ao rebaixamento do nível da água que faz emergir pastos naturais, formados basicamente de herbáceas e arbustos, de grande valor nutritivo para o gado. A atividade pesqueira é praticada durante todo o ano, tendo maior prática na época da seca, pois ao decorrer da temporada das águas baixas, os peixes se concentram nas áreas lacustres que permanecem, facilitando assim a coleta por parte dos pescadores. A agricultura é praticada num sistema que emprega poucos recursos tecnológicos, predominando a técnica de corte e queima. Novas áreas são abertas nos remanescentes florestais, ocorrendo o cultivo. Ao fim do ciclo, as áreas são queimadas de modo a incorporar nutrientes no solo. O plantio na região é majoritariamente de mandioca, que é destinada em grande parte para a produção de farinha. 


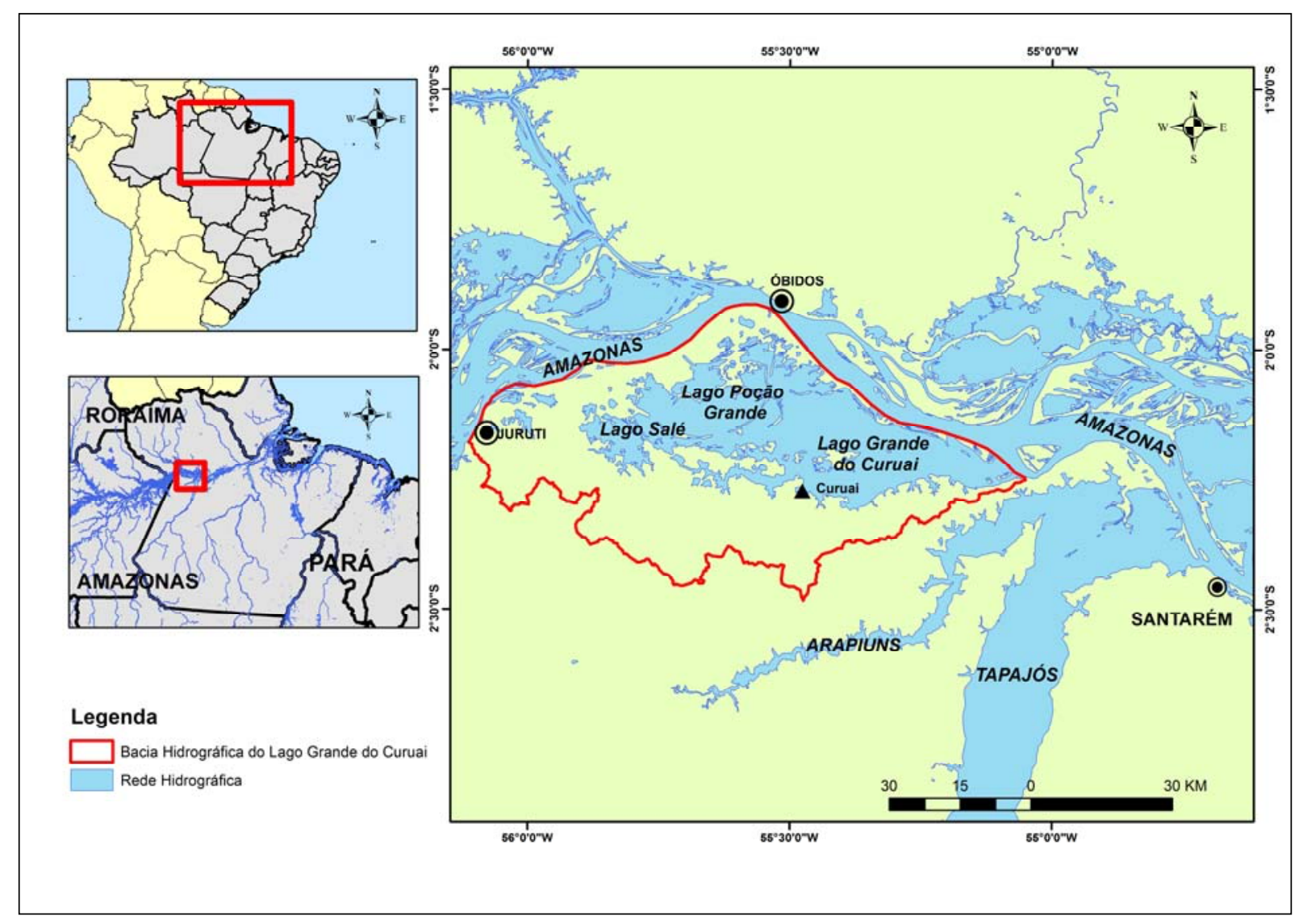

Figura 13: Localização da Área de Estudo. Fonte: elaborado pelo autor.

As áreas de pasto e roça ocorrem dispersas em praticamente todo o território, em parcelas de pouca extensão, dificilmente ultrapassando os 10 hectares. A fitofisionomia da bacia hidrográfica do Lago Grande do Curuai engloba basicamente áreas de vegetação secundária e de remanescentes florestais explorados pelas atividades extrativistas. Nas áreas mais preservadas, ao sul da bacia, é possível encontrar árvores de grande porte, características de floresta ombrófila densa. Ocorrem áreas de manchas de cerrado de expressivo tamanho ao leste da bacia, manchas essas decorrentes de diferenças litológicas com o restante da região de estudo. Inserido no contexto da região de terra firme, encontra-se o Projeto de Assentamento Agroextrativista (PAE) Lago Grande criado pela Portaria Incra/SR30/ n 31 de 2005, onde são desenvolvidas as atividades de pecuária e agricultura. O PAE surgiu como uma demanda dos agricultores da região, de forma a dar-lhes institucionalização frente a pressões externas de mineradoras e grandes pecuaristas que vem ocorrendo no entorno da região. 


\section{MATERIAIS E MÉTODOS}

Para a classificação das imagens e posterior identificação das dinâmicas, foram utilizados procedimentos de processamento digital de imagens. Conforme Meneses (2012), esses procedimentos têm por objetivo facilitar a identificação e extração de informações das imagens.

\section{Processamento das Imagens Landsat TM e ETM+}

Para cobrir a área de estudo, foram utilizadas duas cenas, referentes as órbitas-ponto 228-61 e 228-62. Tanto no satélite Landsat 5 como no Landsat 7 são necessárias duas cenas para cobrir a área de estudo. As imagens utilizadas são todas do mês de outubro, época em que há uma menor cobertura de nuvens. O período também coincide com o momento da vazante, procurando assim reduzir os efeitos da variação do nível da água neste estudo. A escolha do intervalo dos anos deveu-se a disponibilidade das imagens, sendo os anos de 1985, 1997 e 2014 os que possuam imagens com melhor qualidade para as análises (Tabela 3). As imagens foram obtidas no site http://earthexplorer.usgs.gov/, um banco de dados do Serviço Geológico Americano (USGS).

Tabela 3: Imagens Landsat utilizadas. Fonte: elaborado pelo autor.

\begin{tabular}{|c|c|c|c|c|c|}
\hline ÓRBITA & PONTO & DIA & MÊS & ANO & SENSOR \\
\hline \multirow{2}{*}{228} & 61 & \multirow{2}{*}{5} & \multirow{2}{*}{ OUTUBRO } & \multirow{2}{*}{1985} & \multirow{2}{*}{$\mathrm{TM}$} \\
\hline & 62 & & & & \\
\hline \multirow{2}{*}{228} & 61 & \multirow{2}{*}{6} & \multirow{2}{*}{ OUTUBRO } & \multirow{2}{*}{1997} & \multirow{2}{*}{$\mathrm{TM}$} \\
\hline & 62 & & & & \\
\hline \multirow[b]{2}{*}{228} & 61 & \multirow[b]{2}{*}{29} & \multirow{2}{*}{ OUTUBRO } & \multirow[b]{2}{*}{2014} & \multirow[b]{2}{*}{ ETM+ } \\
\hline & 62 & & & & \\
\hline
\end{tabular}

Após a obtenção das imagens, foi realizado o georreferenciamento. Para isso foi utilizada como referência imagens do Geocover, que é um projeto de mapeamento da superfície da terra que tem como base mosaicos de imagens do Landsat 7 (Embrapa, 2014). Esse mosaico é um produto ortorretificado e registrado, podendo ser tomado como base para o georreferenciamento. O mosaico Geocover também foi adqurido no site Earth Explorer (http://earthexplorer.usgs.gov). Após o georreferenciamento, o erro de posicionamento demonstrado pelo Root Mean Square (RMS) foi inferior a 0,95 pixel em todas as cenas. 
No caso da imagem Landsat 7, além das correções geométricas, foi necessária uma etapa adicional de pré-processamento. Devido a um defeito em um dos coletores de dados do satélite, a partir de maio de 2003 cerca de 22\% da área das cenas possuem “gaps”, que são faixas com ausência de dados nas cenas do satélite. (Embrapa, 2014). Para correção desses “gaps” foi utilizado o algoritmo "Landsat Gapfill”, do software ENVI. Entre duas cenas com diferentes resoluções temporais, cada faixa de gaps distribuída nas imagens não está rigorosamente alinhada na mesma posição geográfica da cena seguinte, pois ocorre uma variação entre as imagens. Logo, é possível realizar a correção do gap fill com cenas Landsat 7 de datas mais próximas. Para essa correção de gap, foram utilizadas imagens Landsat 7 de 23 de outubro de 2012.

A bacia hidrográfica do Lago Grande do Curuai está inserida em duas cenas, o que requereu a realização de um mosaico, que consiste na união das imagens distintas num único arquivo. Esse procedimento, assim como o georreferenciamento, foi realizado no software ENVI, específico para tratamento de imagens de satélite. Após o mosaico, foram delimitadas duas máscaras referentes as áreas de várzea e terra firme, a fim de facilitar a classificação e evitar a confusão entre os alvos. Essa delimitação foi construída a partir de curvas de nível extraídas do SRTM (Shuttle Radar Topography Mission), que foi uma missão espacial que objetivou obter um modelo digital de terreno de todo planeta terra, gerando cartas topográficas digitais terrestres de alta resolução (Embrapa, 2014). As regiões de maior elevação do terreno foram delimitadas como zona de terra firme. Por outro lado, as áreas mais baixas foram delimitadas como zona de várzea.

Após o georreferenciamento e montagem dos mosaicos, foi realizada a classificação espectral das imagens. Para essa etapa, foi utilizada classificação supervisionada, pelo método da Máxima Verossimilhança. O método considera a ponderação das distâncias médias, utilizando parâmetros estatísticos de distribuição dos pixels dentro de uma determinada classe (Meneses, 2012). Para a obtenção de um bom resultado com esta classificação é necessária a escolha de um número razoavelmente elevado de pixels para cada amostra de treinamento da classe, e que estes tenham uma distribuição estatística próxima da distribuição normal (Meneses, 2012).

As classes foram determinadas a partir das observações de campo e do padrão de assinaturas espectrais das imagens Landsat. A partir da ferramenta "Region of Interest", as amostras foram coletadas no ENVI, sendo determinadas áreas de treinamento distintas para a várzea e a terra firme. Para a terra firme, as classes definidas foram: floresta de terra firme, 
vegetação secundária (capoeira), pasto, roça, área urbana e campo natural (cerrado). Para a várzea, as classes serão: floresta de várzea, pasto natural e hidrografia. Ainda foram consideradas as classes residuais: nuvem e sombra de nuvem (Anexo L).

Posteriormente à classificação, foram realizadas correções dos resultados obtidos, através de filtros, onde foi empregada a ferramenta do ENVI denominada "Majority Filter". Segundo Meneses (2012), num filtro majoritário a célula central, a partir de uma janela de tamanho opcional, tem calculados seus pixels vizinhos. A partir do valor predominante nos vizinhos, esse valor de pixel central é alterado em função do valor majoritário. Esse filtro implica numa suavização e generalização do resultado, a fim de eliminar “pixels isolados”.

Por fim, foram confeccionadas duas máscaras: uma máscara de resíduos e uma máscara de maior nível d’água. Na máscara de resíduos, os arquivos referentes à nuvens e sombras de nuvens das três datas foram agrupados em um só arquivo. A máscara de maior nível d’água foi obtida a partir do resultado das classificações, onde se constatou que o ano de 1985 possuía maior lâmina d’água na várzea. Os resíduos e a lâmina d’água foram então subtraídos das classificações resultantes das três datas. Essa etapa foi feita de forma a dirimir a influência dos resíduos e do nível d’água no cálculo das métricas das demais classes. Assim, a classe de "Hidrografia" e de "Resíduos" não adentraram no cálculo das métricas de paisagem. Por consequência da aplicação das máscaras, a área analisada teve uma redução de $3.807,54 \mathrm{~km}^{2}$ para $2.614,47 \mathrm{~km}^{2}$, em função da subtração de 1.656,35 km² de resíduos e hidrografia.

\section{Validação de Campo}

Após o processo de filtragem pós-classificatório, foi realizada a validação, medindo a acurácia por meio do índice Kappa. Segundo Meneses (2012), a acurácia é expressa a partir de índices, que são calculados em função de matrizes de erros ou de confusão. Essas matrizes expressam a concordância entre a imagem que está classificada e os dados utilizados como referência. Dessa forma, as matrizes comparam a relação entre os dados de verdade terrestre (os chamados “dados de referência”) e os correspondentes dados da classificação. Conforme Meneses (2012), outras medidas descritivas podem ser obtidas por meio das matrizes de confusão, como índice Kappa. O índice Kappa varia de 0 (concordância nula) a 1 (concordância perfeita). 
Os dados de referência que foram utilizados para validação da classificação foram os pontos coletados em três trabalhos de campo, no caso da classificação mais recente (2014), e as áreas de coleta de amostras das classes, no caso das imagens de 1997 e 1985 . A primeira campanha de coleta de dados de campo foi realizada entre os dias 25 de maio e 6 de junho de 2014 (concentrada em terra firme, durante a época de cheia na várzea); a segunda realizada entre os dias 24 de novembro e 3 de dezembro de 2014 (concentrada na várzea, durante a época de seca); a terceira, entre 4 de maio e 13 de maio de 2015 (concentrada em terra firme, durante a época de cheia na várzea). As missões tiveram propósitos distintos tendo em vista as condições climáticas, a dificuldade de acesso e as peculiaridades da região Amazônica. Para coleta dos pontos, foi utilizado um equipamento GPS.

Para o ano de 2014, foram tomados como verdade de campo os pontos coletados nos trabalhos de campo. Dos 251 pontos coletados, apenas 233 foram aproveitados. Os 18 pontos descartados correspondem a pontos de passagem (como pontes e vilas), pontos localizados fora da área de estudo e a classes e elementos da paisagem que foram desconsiderados posteriormente, como igarapés e matas de galeria. Para os anos de 1997 e 1985, os pontos tomados como "verdade” foram coletados nas áreas das imagens de satélite onde foram amostrados os pixels de referência de cada classe por meio de fotointerpretação. Como foram realizadas classificações distintas para as áreas de várzea e terra firme, as matrizes também são correspondentes a cada área.

\section{Aplicação das métricas da paisagem}

As métricas de paisagem têm entre seus objetivos o propósito de caracterizar no tempo e no espaço padrões de uso e cobertura da terra (Turner e Carpenter, 1998). Dessa forma, as métricas permitem identificar alterações temporais nas paisagens. As métricas de paisagens são ferramentas da ecologia de paisagens, um ramo da ecologia que busca compreender as relações estabelecidas entre a estrutura, função e a dinâmica dos ecossistemas (Forman e Godron, 1986). A ecologia de paisagens tem o diferencial de considerar a integração homemmeio como forma primordial de modificação das paisagens (Soares Filho, 1998). Os

principais elementos de ecologia de paisagens são: fragmento, corredor e matriz. Metzger (2001) aponta que um fragmento é uma mancha originada por fragmentação, sendo uma subdivisão promovida pelo homem de uma unidade que inicialmente apresentava-se de forma contínua. Já a matriz é a unidade que controla a dinâmica da paisagem, em geral recobrindo a maior parte da paisagem (Metzger, 2001). 
Após a validação da classificação pelo índice Kappa, os arquivos foram exportados para o formato vetorial, com o propósito de serem realizados os cálculos das métricas para as três datas, utilizando as métricas de paisagens nos dois recortes espaciais de estudo. O primeiro recorte espacial engloba toda a zona de estudo, que é a bacia hidrográfica do Lago Grande do Curuai.

O recorte espacial das zonas da paisagem (Figura 14) teve suas áreas definidas a partir de metodologias utilizadas em trabalhos anteriores, destacando-se os de Beringuer (et al, 1997), Deffontaines (1985) e Lizet e Ravignan (1987). Essas metodologias se apoiam basicamente em trabalhos de campo, associados a uma revisão dos sistemas produtivos e usos empregados por atividades antrópicas nas áreas de estudo e análises de imagens de satélites. No caso da área de estudo, a delimitação levou em conta os sistemas produtivos presentes na bacia hidrográfica do Lago Grande do Curuai, sua localização geográfica e os usos que são estabelecidos pelos habitantes da região. Totalizando seis zonas, essa definição ocorreu após as observações de campo e análises de imagens de satélite. Os componentes da paisagem são equivalentes as classes de uso e cobertura, sendo divididos em componentes de terra firme e em componentes de várzea. Os componentes de várzea são: floresta de várzea, pasto natural e hidrografia. Os componentes de terra firme são: floresta de terra firme, vegetação secundária, roça, pasto, campo natural e área urbana.

- Zona da paisagem do sistema pastoral de várzea baixa (Zona 1): Região mais baixa da várzea, permanecendo maior parte do tempo inundada, tendo como matriz a água.

- Zona da paisagem do sistema pastoral de várzea alta (Zona 2): Região mais alta da várzea, onde predominam arbustos e pastos naturais, alagando durante o pulso de inundação do rio Amazonas.

- Zona da paisagem do sistema agro-pastoral de terra firme (Zona 3): Região onde as atividades de agricultura e pecuária se mesclam e produzem uma zona já bastante alterada; tem como matriz a vegetação secundária.

- Zona da paisagem do sistema agro-florestal de terra firme (Zona 4): Região onde ocorre alteração por atividades antrópicas, mas com a floresta de terra firme mantendo-se como matriz.

- Zona da paisagem do ecossistema de savana de terra firme (Zona 5): ocorrendo a leste da bacia, consiste basicamente em uma zona de predominância de redutos de cerrados, denominados campos naturais. 
- Zona da paisagem do ecossistema de floresta de terra firme (Zona 6): zona que consiste basicamente em floresta.

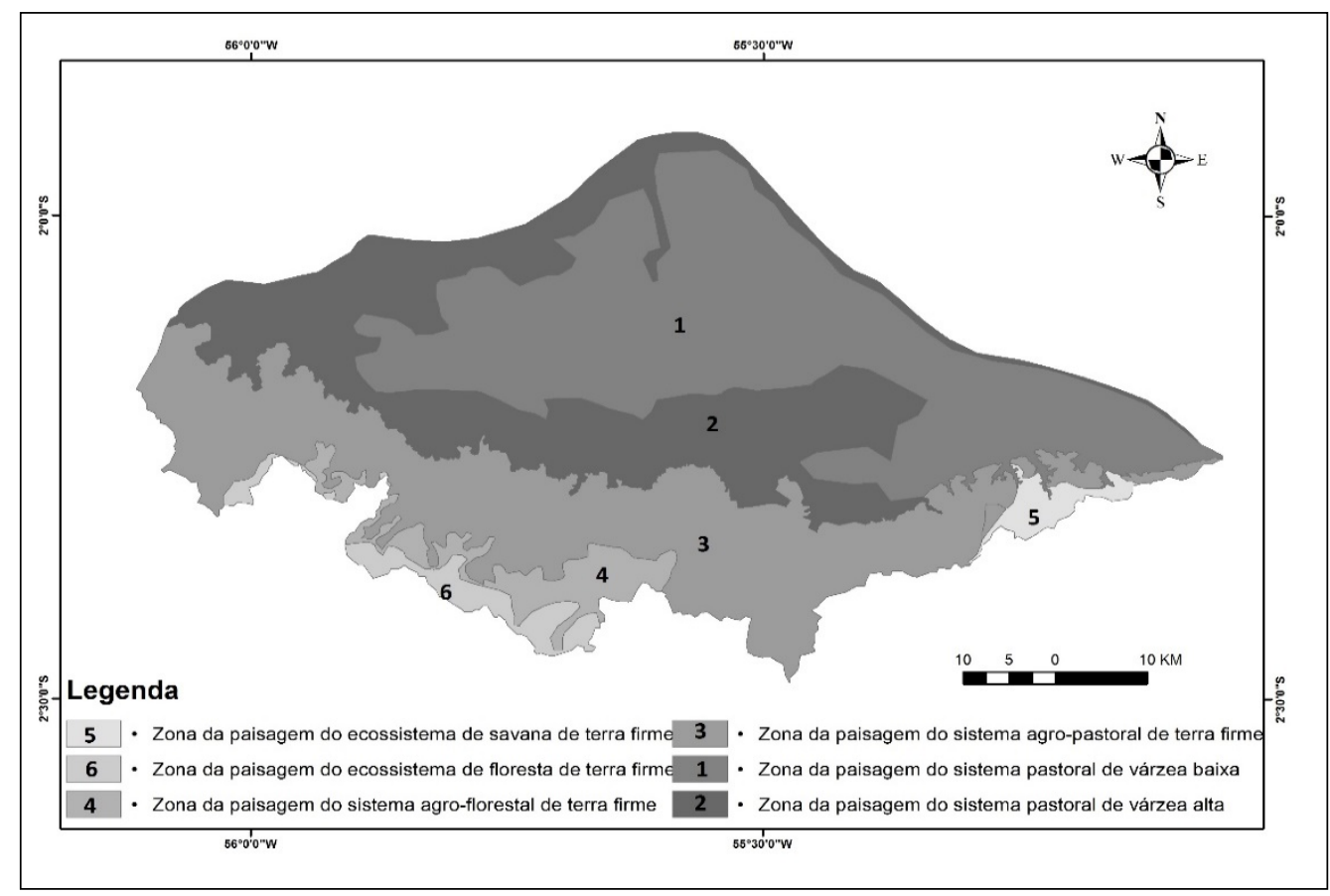

Figura 14: Delimitação das Zonas da Paisagem (segundo recorte geográfico de estudo). Fonte: elaborado pelo autor

Na bacia hidrográfica do Lago Grande do Curuai, as maiores alterações na paisagem são advindas de práticas antrópicas, como a agricultura e a pecuária. Para o cálculo das métricas, foi aplicada a extensão gratuita para o ArcGIS chamada Patch Analyst. Para o recorte espacial da bacia e no recorte espacial das zonas da paisagem, serão estabelecidos três cálculos de métricas: o do número de fragmentos (NUMP), o tamanho médio dos fragmentos (MPS), o da área dos fragmentos (CA). McGarigal and Marks (1995) apresentam a definição das métricas.

A métrica NUMP quantifica o número de fragmentos ou manchas existentes em cada classe. No caso da matriz, um amento nessa métrica indica que ela tem sido dividida em outros fragmentos, indicando uma perturbação; no caso das classes de uso antrópico, um aumento nessa métrica aponta que esse elemento pode estar se tornando mais representativo na paisagem. A métrica área da classe (CA) faz a soma das áreas de todas as manchas pertencentes a uma determinada classe. Um aumento nessa métrica pode indicar que o elemento analisado está mais representativo; já um decréscimo aponta para uma queda da representatividade do elemento. O tamanho médio dos fragmentos (MPS) é calculado com 
base na área total da classe dividido pelo seu respectivo número de fragmentos, o que permite estimar o tamanho médio para seus fragmentos; sua utilização possibilita avaliar se um determinado elemento da paisagem tem se tornado mais consolidado (caso o índice esteja aumentando) ou menos representativo (caso o índice esteja em decréscimo).

\section{RESULTADOS E DISCUSSÃO}

\section{Análise Estatística da Classificação}

Para a matriz da terra firme, no ano de 2014, foram inseridos 131 pontos de verdade de campo. Desses, 116 coincidiram com a classificação proposta, o que gerou um coeficiente Kappa de 0,8595, com acurácia global de 88,55\%. Para a matriz da várzea, foram 102 pontos de verdade de campo, os quais 98 coincidiram com a classificação, gerando um coeficiente Kappa de 0.9477, com acurácia global de 96,07\%. Tomando como base a quantidade de pontos coletados para validação da classificação do ano de 2014, foi estabelecida a quantidade média de 100 pontos em várzea e 100 pontos em terra firme, totalizando aproximadamente 200 pontos, para validação das imagens de 1997 e 1985. Esses pontos foram coletados nas áreas de amostra de pixels para a classificação. Essas áreas foram determinadas por fotointerpretação.

A matriz da terra firme de 1985 teve 76 pontos de acerto, com coeficiente Kappa de 0,707 e acurácia global de 76\%. Já a matriz de várzea de 1985 teve 92 pontos de acerto, com coeficiente Kappa de 0.8913 e acurácia global de 92\%. Para o ano de 1997, a matriz de terra firme apontou 83 pontos de acerto, com coeficiente Kappa de 0.77 e acurácia global de 82\%; a matriz da várzea apontou uma correlação entre 91 pontos, atingindo um coeficiente Kappa 0.88 e uma acurácia global de 91\%; a matriz de terra firme. Conforme proposto por Landis e Koch (1977), as classificações encontram-se todas na escala "muito boa” e “excelente”, com índice Kappa entre 0,6 - 0,8 e 0,8 -1,0, respectivamente. A distinção da classificação e da coleta dos alvos em áreas de terra firme e áreas de várzea facilitou o trabalho e trouxe mais qualidade para a classificação, diminuindo a mistura entre as classes. As matrizes encontramse nos Anexos A, B e C.

\section{Análise Temporal da Classificação e Aplicação das Métricas de Paisagem}

Após o processamento das imagens, foram confeccionados três mapas temáticos com as classificações, apresentados nas figuras dos Anexos F, G e H. Inicialmente, através de uma 
observação visual, percebe-se que de forma geral há uma variação das áreas de floresta de terra firme e um incremento das classes vegetação secundária/capoeira e pasto.

\section{Análise da paisagem do recorte geográfico da Bacia}

No primeiro recorte espacial, que é a bacia hidrográfica como um todo, o resultado da aplicação das métricas trouxe os resultados apresentados na Figura 15 e no Anexo D. Na classe “Floresta de Terra Firme”, ocorre uma diminuição entre 1985 e 2014 em mais de 30 mil hectares. Em 1985, as áreas de "Floresta de Terra Firme” correspondem a aproximadamente 86 mil hectares (33\% da área), valor que é reduzido para aproximadamente 58 mil hectares em 2014 (22\% da área). A diminuição de florestas no ambiente das planícies de inundação também foi apontada por Hess (2003) e Renó (2008). Ocorre também um aumento do número de fragmentos dessa classe. Por ser a matriz, considera-se que esse aumento do número de fragmentos é um indicativo da fragmentação dessa classe.

Os fragmentos de "Floresta de Terra Firme" têm sido divididos em fragmentos de menor área, como pode ser visto pela métrica MPS, com diminuição do tamanho médio dos fragmentos de floresta em quase 50 hectares. A associação desses fatores (diminuição do número de fragmentos e diminuição da área da classe) são indicativos de que ocorre mudanças no tipo de cobertura da área, como a substituição da cobertura vegetal natural por atividades antrópicas (roça e pasto) e principalmente por vegetação secundária/capoeira.

Ao se abrir novas áreas de atividades, a vegetação original é substituída, o que diminui o seu tamanho em área e aumenta a quantidade de fragmentos. Entretanto, o aumento em termos de área e de número de fragmentos das classes de atividades antrópicas é moderado na série estudada; os pastos aumentam em área de 12 mil hectares (4,65\%) para 16 mil hectares (6,17\%); as roças se mantêm estáveis, de 4,4 mil hectares (1,69\%) para 4,3 mil hectares (1,68\%). O tamanho médio e o número de fragmentos indicam que os pastos e as roças são de pouca extensão e ocorrem dispersos pelo território (Figura 15). É importante ressaltar que a limitação da resolução espacial do sensor dos satélites Landsat pode ter subestimado uma parte das áreas de pasto e roça, tendo em vista que a menor área mapeada tanto pelo TM quanto pelo ETM+ é de $900 \mathrm{~m}^{2}$ (menos de 1 hectare). 
NUMP

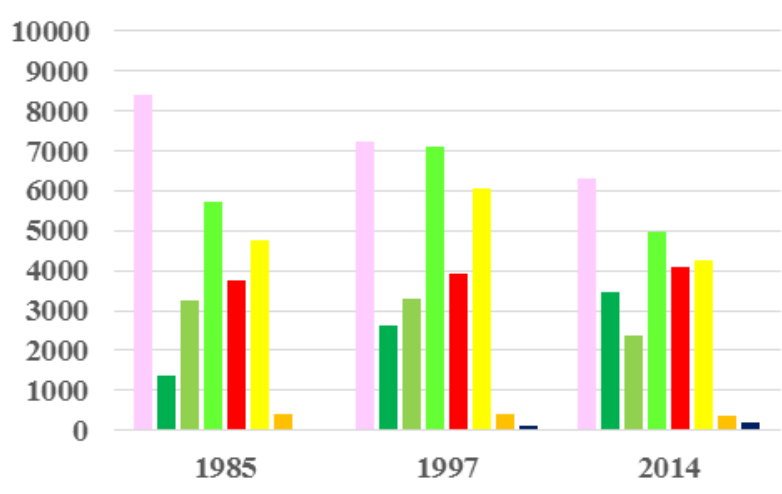

CA

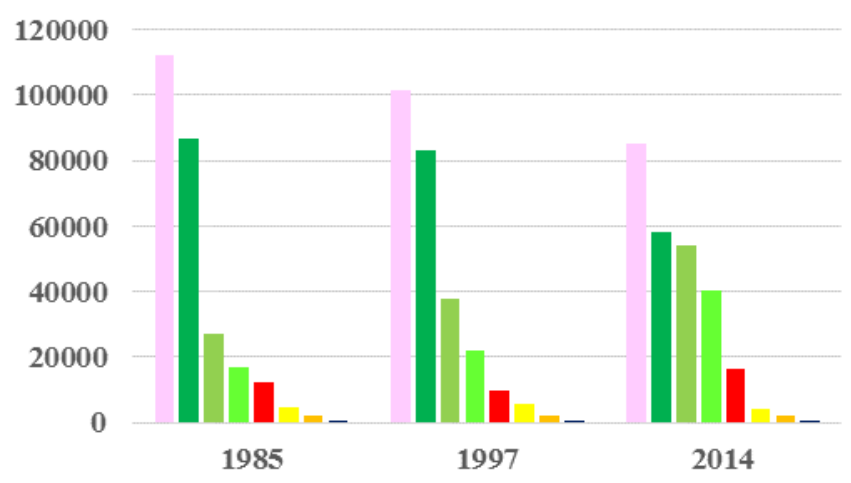

MPS

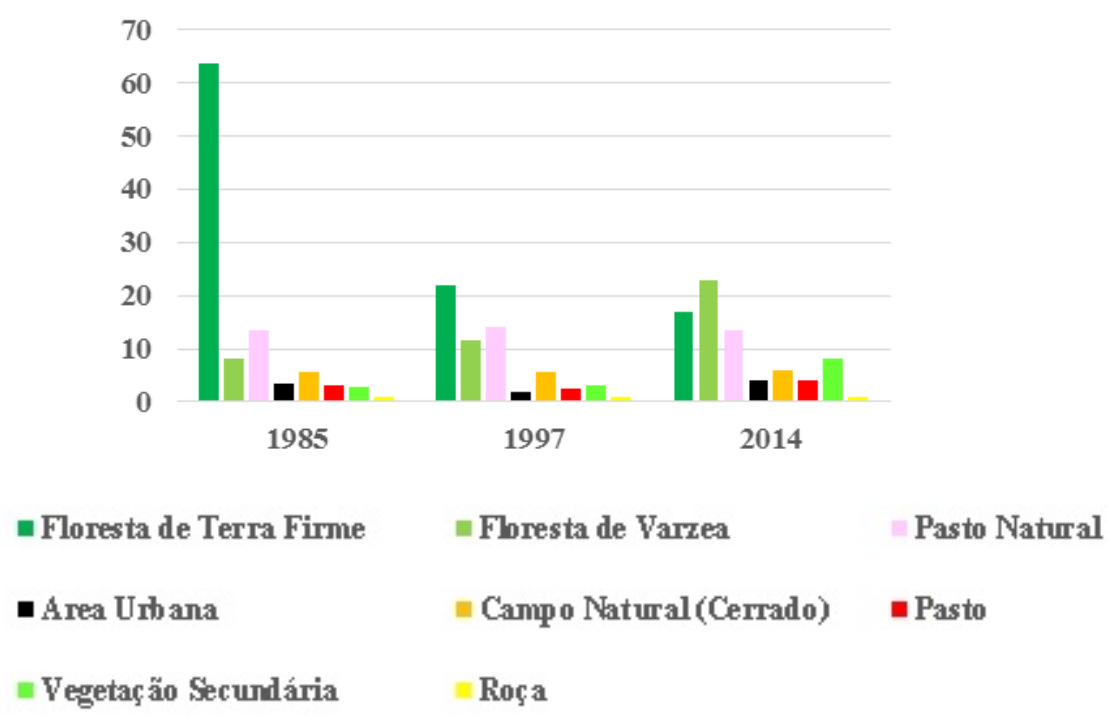

Figura 15: Métricas Aplicadas na Recorte Espacial da Bacia: Número de Fragmentos (em valores totais), Área da Classe e Tamanho Médio do Fragmento (em hectares), Índice de Forma Médio (Variação entre 1 e 2).

A vegetação secundária é a classe que tem mais incremento, mais que dobrando de tamanho em 30 anos (de 6,38\% em 1985 para 15,45\% em 2014). Segundo Brown e Lugo (1990), a vegetação secundária é aquela formada a partir de distúrbios antrópicos na vegetação original; a vegetação secundária tanto pode ser resultante de atividades antrópicas, representando uma forma de perturbação na cobertura florestal original, como também um estágio inicial de recuperação de áreas que foram desmatadas. Quanto a classe "Floresta de Várzea”, ocorre um incremento da mesma em quase 20 mil hectares (passando de 10,29\% para 20,63\% do total), expressa pelo aumento dos valores da métrica área da classe (Figura 16). A diminuição do número de fragmentos associada ao aumento da classe indica que há um acréscimo da floresta de várzea, com essa se tornando mais coesa e densa. A estabilidade do índice de forma médio indica que há uma estabilização de alterações nesse ambiente. Os 
dados quantitativos das alterações das encontram-se nos anexos F e G. As conversões mais significativas entre as classes foram as de vegetação secundária e de roça; 71,92\% e 88,23\%, respectivamente, das áreas em 1985 haviam sido substituídas por outra cobertura em 1997. A Floresta de Terra Firme teve uma conversão de 29,94\%. Entre 1997 e 2014, as maiores transições são entre as classes de pasto e roça (72,69\% e 88,23\%), indicando grande transitoriedade dessas classes entre 1997 e 2014. A Floresta de Terra Firme teve uma taxa de conversão de 22,53\%.

\section{Análise da paisagem do recorte geográfico das Zonas da Paisagem}

No recorte espacial que engloba as seis zonas da paisagem, é possível perceber como a dinâmica de uso e cobertura da terra ocorre de forma heterogênea na paisagem. A divisão da área de estudo em recortes espaciais, conforme demonstrado em trabalhos anteriores como os de Laques (1993) e Escada (2003), facilita as análises e traz um aporte singular para a compreensão das dinâmicas. Nas zonas 1 e 2 (zona da paisagem do sistema pastoral de várzea alta e baixa), a maior diferença encontrada entre as classes é um significativo incremento da “Floresta de Várzea”, com consequente diminuição do "Pasto Natural” (Figura 16 e Anexo E).

A zona da paisagem 3 (sistema agro-pastoral de terra firme) é a grande concentradora de dinâmicas na área de estudo. Nessa zona, ocorre um decréscimo da classe "Floresta de Terra Firme” em área da classe, em tamanho médio de fragmentos e aumento no número de fragmentos, demonstrando que há uma substituição da cobertura vegetal natural. Entretanto, a classe de maior incremento é a "Vegetação Secundária”, com aumento de área da classe. Além disso, o número de fragmentos de "Vegetação Secundária” tem uma redução; entretanto, essa redução é acompanhada de um aumento do tamanho médio dos fragmentos, o que indica que essa classe está se tornando mais coesa e conexa. A classe área urbana tem incremento em área, número de fragmentos e tamanho médio de fragmentos; entretanto ainda corresponde a uma parcela muito pequena da paisagem, com um crescimento de 0,06\% para 0,28\% da área (Figura 17 e Anexo E).

A classe "Roça” se mantêm praticamente estável em termos de área. O tamanho médio de fragmento é inferior a 1 hectare nas três datas, o que demonstra que a classe, embora bastante representativa em termos de número de fragmentos, é pouco representativa em tamanho de área e ocorre de forma bastante dispersa no ambiente. As áreas de "Pasto" possuem incremento, entretanto esse se resume a menos de 5 mil hectares em quase 30 anos de 
diferença, passando de 10.879,17 hectares (4,65\%) para 15.257 hectares (6,17\%). O número de fragmentos da classe se manteve estável, entretanto ocorre um incremento no tamanho médio. Dessa forma, os pastos têm se tornado maiores em relação ao primeiro ano de análise, embora não tão numerosos em termo de área. É importante destacar que na zona da paisagem 3 a dinâmica torna-se mais acelerada de 1997 para 2014 (Figura 17 e Anexo E).

A zona da paisagem 4 (zona da paisagem do sistema agro-florestal de terra firme) tem um decréscimo da cobertura florestal original, com acréscimo de roça, pasto e vegetação secundária. Entretanto esse incremento ocorre de forma bem menor quando comparado com a zona 3. A "Floresta de Terra Firme" diminui aproximadamente 3 mil hectares, enquanto ocorre um incremento em área de 1,2 mil ha de vegetação secundária, 300 hectares de pasto e uma estabilização das áreas de roça. A "Vegetação Secundária” tem também aumento do número e do tamanho médio dos fragmentos, mostrando que está se tornando mais coesa (Figura 17 e Anexo E).

A zona da paisagem 5 (zona da paisagem do ecossistema de savana de terra firme) tem em sua matriz uma grande área de cerrado que existe no leste da bacia, em função de mudanças litológicas. Nessa zona o “Campo Natural” se mantêm estável em todas as suas métricas. A classe onde há mais dinâmica é a diminuição da "Floresta de Terra Firme" e incrementos de "Roça” e "Vegetação Secundária”. Nessa zona, parte das atividades de pastagem é praticada no próprio cerrado, o que não exige a abertura de novas áreas de pastagem, levando a uma dinâmica incipiente (Figura 18 e Anexo E). A zona da paisagem 6 (Zona da paisagem do ecossistema de floresta de terra firme) é onde ocorre menos alteração: os 400 hectares de "Floresta de Terra Firme” que foram suprimidos entre 1985 e 2014 foram convertidos em sua maioria em "Vegetação Secundária”. As áreas de roça (tamanho médio inferior a 1 hectare nas três datas) e pasto (apenas 15 fragmentos e 33 ha de área em 2015) são ínfimas (Figura 18 e Anexo E). 


\section{ZONA DA PAISAGEM 1}

CA

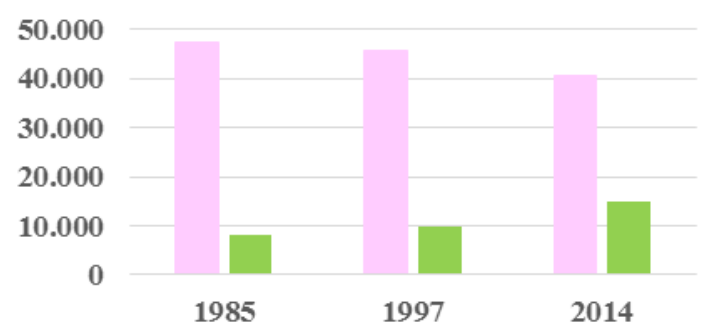

\section{ZONA DA PAISAGEM 2}

CA

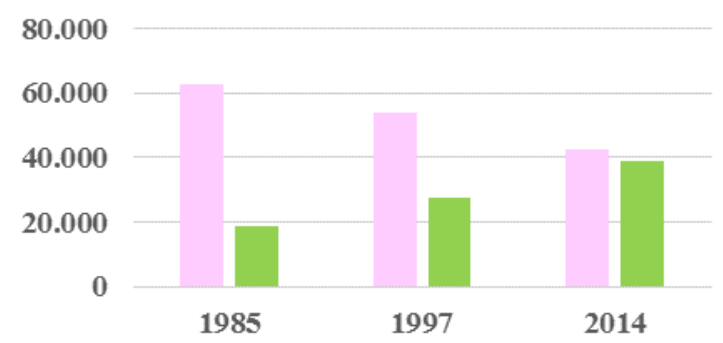

NUMP

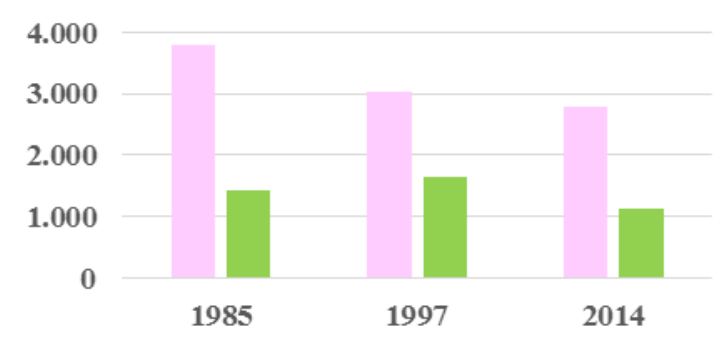

MPS

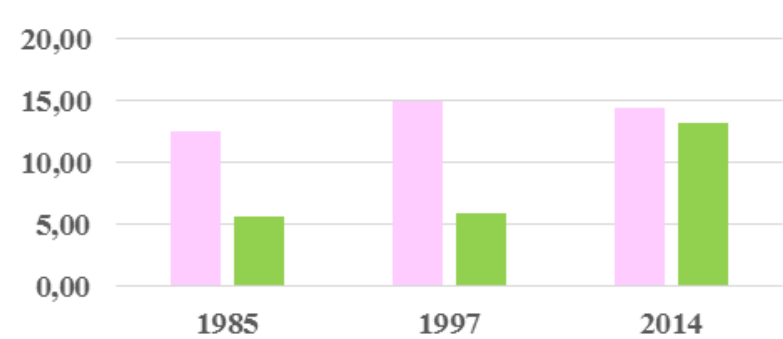

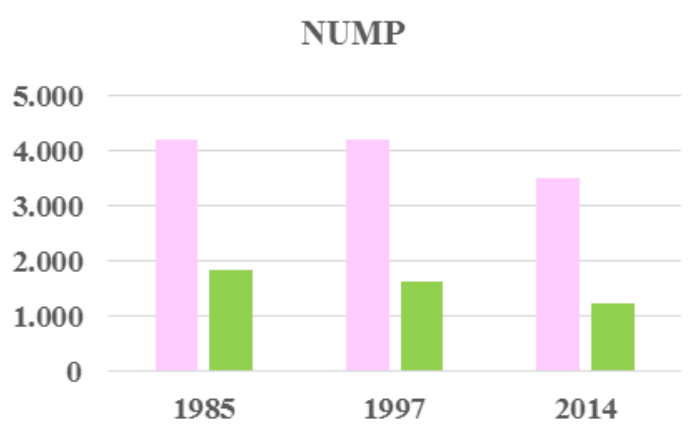

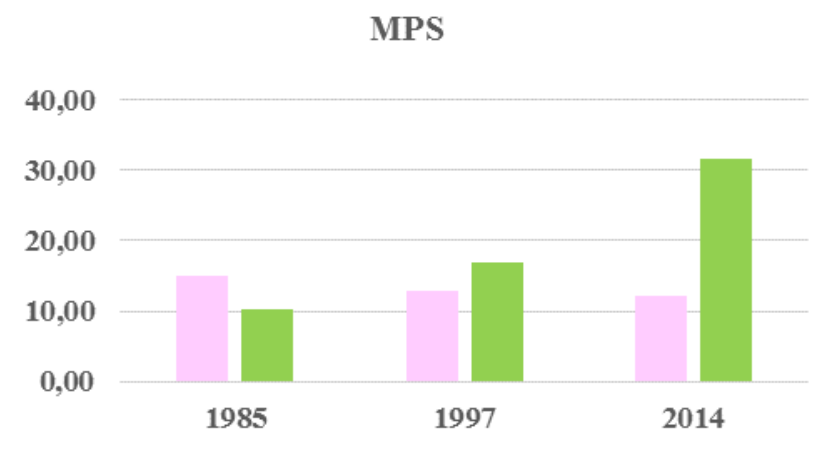

- Floresta de Terra Firme

Floresta de Varzea

Pasto Natural

- Area Urbana

- Campo Natural(Cerrado)

- Pasto

- Vegetação Secundária

Roça

Figura 16: Métricas aplicadas no recorte espacial das Zonas da Paisagem (Zonas 1 e 2): Número de Fragmentos (em valores totais), Área da Classe e Tamanho Médio do Fragmento (em hectares). 


\section{ZONA DA PAISAGEM 3}

CA

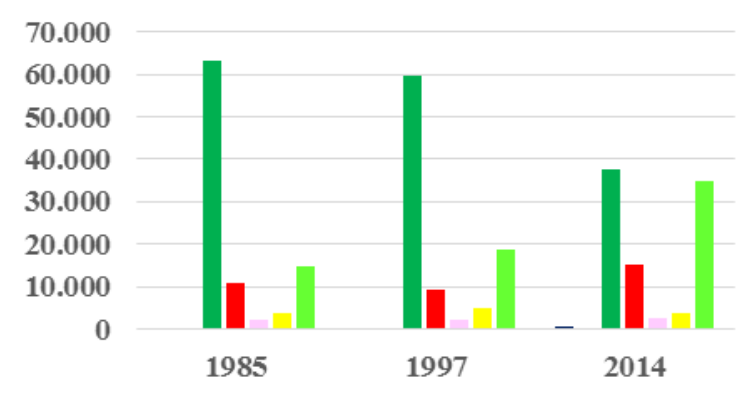

NUMP

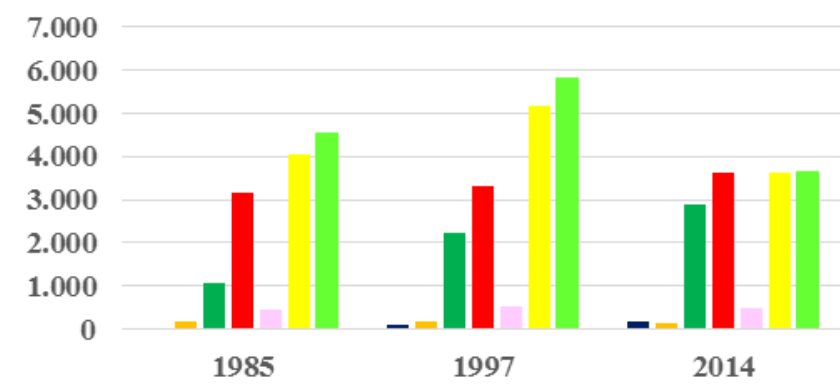

MPS

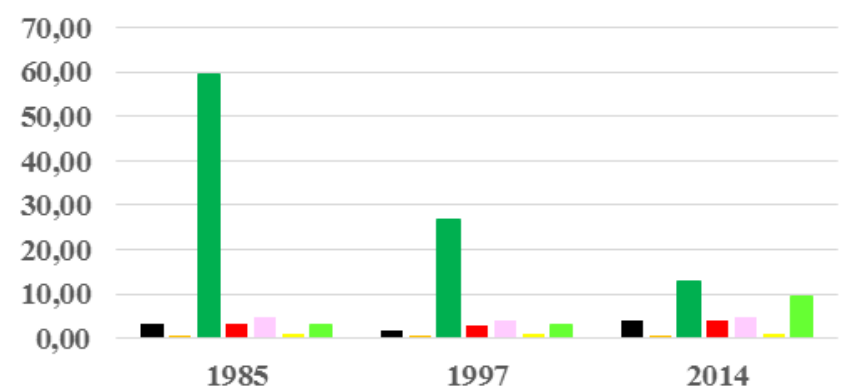

\section{ZONA DA PAISAGEM 4}

CA

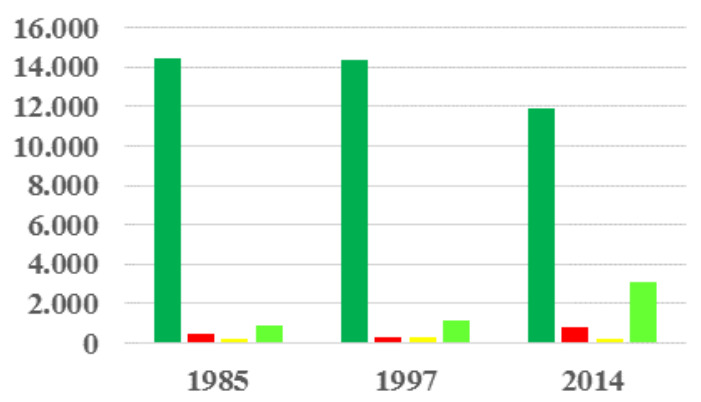

NUMP

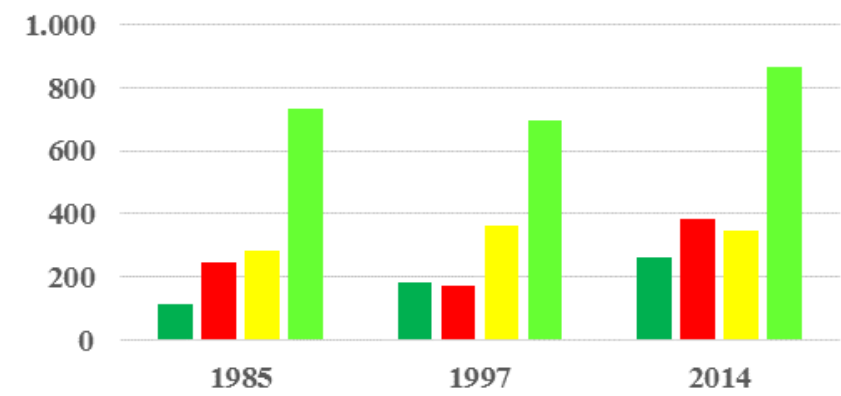

MPS

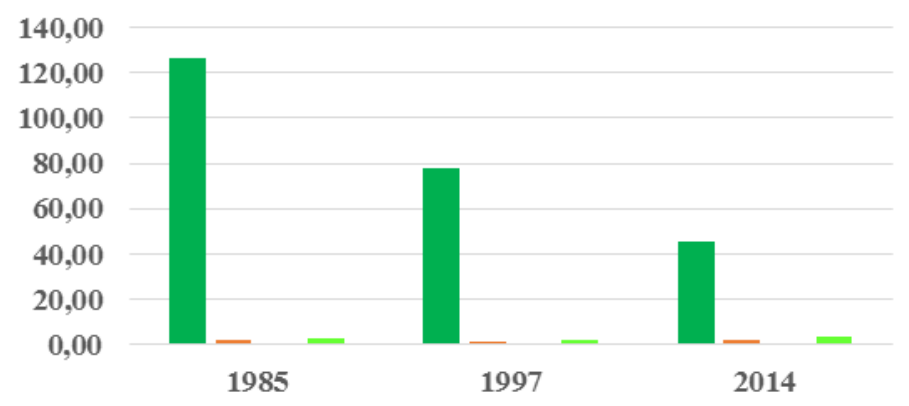

- Floresta de Terra Firme - Floresta de Varzea Pasto Natural

- Area Urbana - Campo Natural(Cerrado) - Pasto

E Vegetação Secundária Roça

Figura 17: Métricas aplicadas no recorte espacial das Zonas da Paisagem (Zonas 3 e 4): Número de Fragmentos (em valores totais), Área da Classe e Tamanho Médio do Fragmento (em hectares) 


\section{ZONA DA PAISAGEM 5}

CA

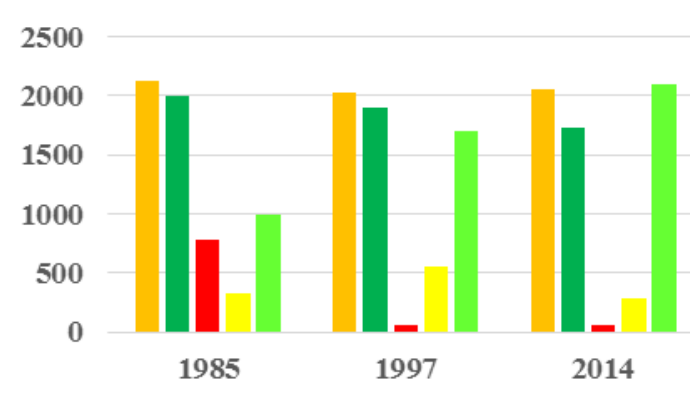

ZONA DA PAISAGEM 6
NUMP

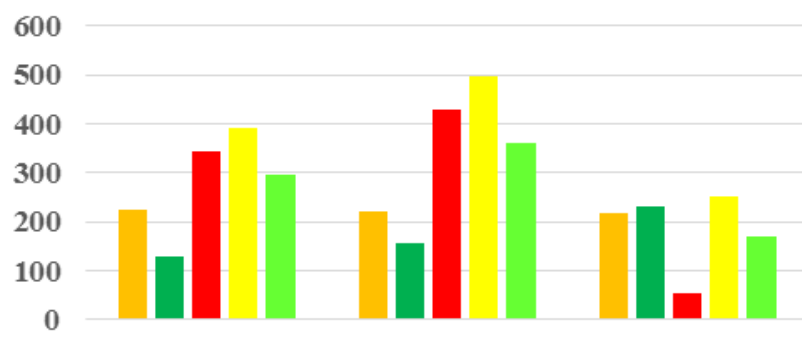

1985

1997

2014

NUMP

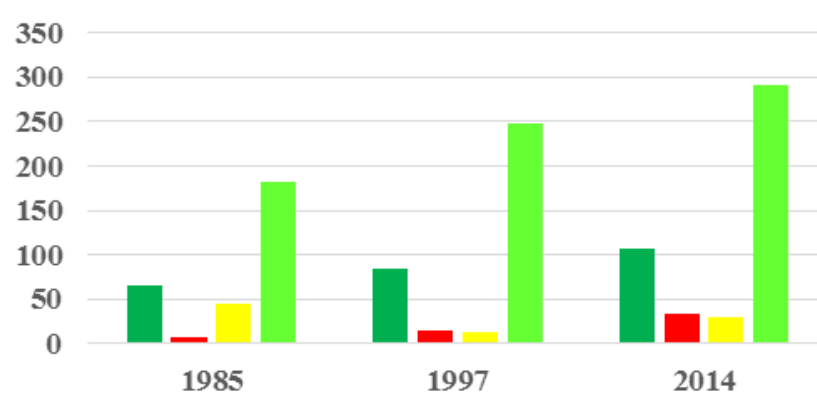

MPS

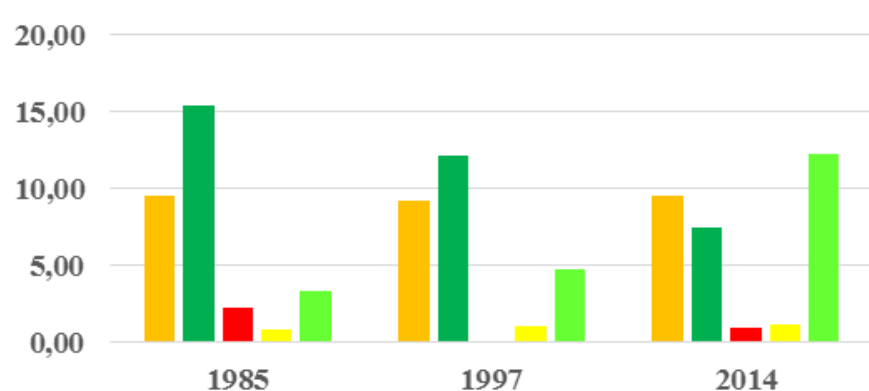

CA

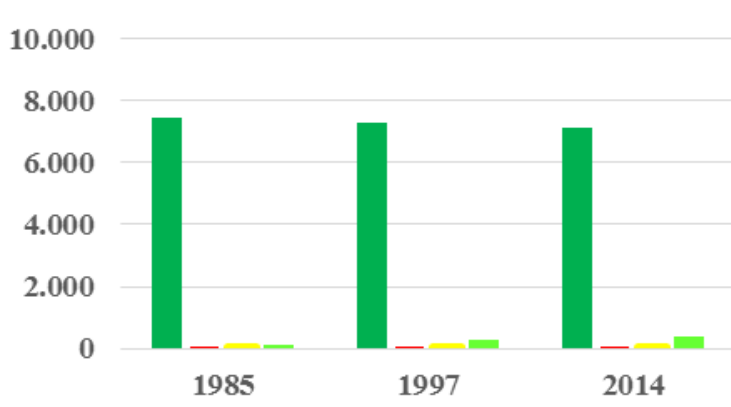

1985

2014

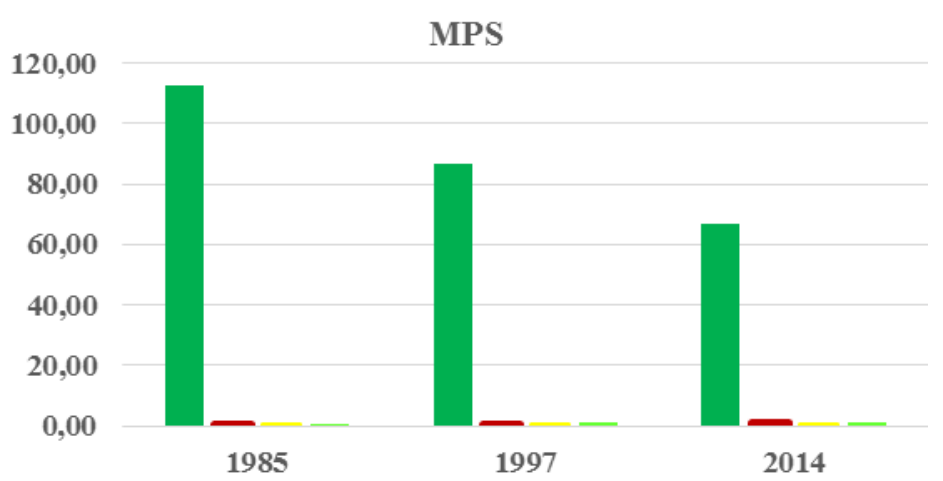

Figura 18: Métricas aplicadas no recorte espacial das Zonas da Paisagem (Zonas 5 e 6): Número de Fragmentos (em valores totais), Área da Classe e Tamanho Médio do Fragmento (em hectares) 


\section{CONCLUSÕES}

Com a exposição dos resultados, podemos concluir que a bacia hidrográfica do Lago Grande do Curuai possui uma dinâmica antrópica moderada quando analisada em seu primeiro recorte geográfico; quando analisada no segundo recorte geográfico (zonas da paisagem), podemos verificar que a dinâmica antrópica é mais acentuada em duas zonas de terra firme (Zona da Paisagem 3 - Sistema Agropastoral de Terra Firme e Zona da Paisagem 4 - Sistema Agroflorestal de Terra Firme), com outras duas zonas de terra firme sofrendo pouca alteração (Zona da Paisagem 5 - Ecossistema de Savana de Terra Firme. Além disso é interessante verificar que a própria dinâmica natural do ambiente é a responsável pelas alterações das zonas da paisagem na várzea. Dessa forma, a divisão da área de estudo em dois recortes geográficos distintos permitiu identificar que a dinâmica de uso e ocupação, que em geral se configurou moderada, em verdade é acentuada em parte da área de estudo.

O histórico de ocupação da região e os sistemas produtivos empregados podem trazer explicações sobre esses resultados. A região do Lago Grande do Curuai tem ocupação historicamente ribeirinha, com as populações estabelecidas ao longo do curso d’água e empregando técnicas de agrícolas distintas de outros locais de ocupação mais recente do Bioma Amazônia. Enquanto nas margens das estradas imperou a distribuição de terras e a retirada total da vegetação para abertura de pastagens e áreas de agricultura, nas áreas de várzea são praticadas técnicas de agricultura rotativa, que ocorre de forma dispersa no território e produzem um processo de ocupação pouco consolidado (Prattes, 2011). Conforme Richers (2010), a agricultura produzida nas regiões das planícies de inundação difere-se bastante do restante da Amazônia, sendo menos impactante ambientalmente, pois demanda menores áreas de cultivo, estando adaptada as desfavoráveis condições edáficas da Amazônia, consistindo na utilização da área e posterior abandono, o que permite a regeneração florestal; em geral, as áreas abandonadas são posteriormente integradas no ciclo produtivo, o que diminui a necessidade de abertura de novas áreas. Isso pode esclarecer por que a classe de maior incremento ser a de vegetação secundária, e as áreas de pasto e roça ocorrem de maneira dispersa e com fragmentos de tamanho reduzido. Isso foi observado também no trabalho de campo.

A cultura rotativa típica de agricultura tradicional de subsistência favorece a regeneração das áreas que foram preteritamente desmatadas. Uma área que poderia ter sido aberta para pastagem em 1985, em 2014 já poderia estar coberta de vegetação secundária. Segundo Almeida (2009), a vegetação secundária exerce várias funções relevantes, sendo uma 
delas o aproveitamento em sistemas agrícolas de baixa tecnologia, favorecendo a reutilização da terra que, no decorrer do tempo, apresenta redução em sua capacidade de suporte agrícola. O sistema de plantio que predomina na região de estudo é o plantio de corte e queima. Conforme Martins (2005), nesse sistema uma área originalmente florestada é derrubada, queimando-se os remanescentes de forma a incorporar nutrientes ao solo. Após anos de utilização que reduz a capacidade fértil do solo essa área é abandonada, migrando-se a atividade para uma nova parcela, que após uma parcela de tempo já está exaurida; esse período de tempo seria necessário para recuperar a primeira parcela.

É fundamental ressaltar também o caráter dinâmico da natureza na área de estudo. O regime de cheia e de seca da planície de inundação onde está inserida a bacia do Lago Grande do Curuai permite que, a cada seis meses, as áreas que não estão inundadas sejam utilizadas para pastagem e agricultura. A economia local é baseada em agricultura de subsistência, pesca e pecuária. Dessa maneira foi desenvolvido um sistema de coexistência da dinâmica da várzea com a de terra firme, o que produz um êxodo semestral de gado da terra firme para várzea, quando a última está seca, e da várzea para terra firme, quando esta encontra-se alagada. Além disso, o aporte de nutrientes do pulso de inundação do rio Amazonas torna a região fértil e permite alguns tipos de colheita durante a época da seca. Sendo assim, essa dinâmica cheia-seca permite um aporte considerável de áreas aptas a práticas agropastoris em várzea, o que diminuiria a pressão em terra firme de abertura de novas áreas e consequente diminuição da cobertura vegetal natural.

\section{AGRADECIMENTOS}

Os autores agradecem à Coordenação de Aperfeiçoamento de Pessoal de Nível Superior (CAPES) pela bolsa de Lucas Garcia Magalhães Peres no Programa de PósGraduação em Geografia da Universidade de Brasília. Agradecem também à FRB (Fondation pour la Recherche sur la Biodiversité (FRB), ao IRD (Institut de Recherche pour le Développement, e ao LMI (Laboratório Misto Internacional), a Federação das Associações de Moradores e Comunidades do Assentamento Agroextrativista da Gleba Lago Grande (FEAGLE) e a Casa Familiar Rural da Vila de Curuai pelo financiamento e apoio para o trabalho de campo.

\section{REFERÊNCIAS BIBLIOGRÁFICAS}

AFFONSO, A. G.; NOVO, E. M. L. M.; MELACK, J. M.; HESS, L. L. Identificação e quantificação do desflorestamento nas áreas alagáveis nos municípios à margem do Rio 
Solimões / Amazonas nos estados do Pará e Amazonas. In: SIMPÓSIO BRASILEIRO DE SENSORIAMENTO REMOTO, 13. (SBSR)., 2007, Florianópolis. Anais... São José dos Campos: INPE, 2007. p. 3235-3242. CD-ROM; On-line. ISBN 978-85-17-00031-7. (INPE14678-PRE/9652). Disponível em: <http://urlib.net/dpi.inpe.br/sbsr@80/2006/11.24.18.53>. Acesso em: 08 fev. 2015.

ALCÂNTARA, E.; STECH, J. L.; BARBOSA, C. C. F.; NOVO, E. M. L. M.; SHIMABUKURO, Y. E. Integração de dados de alta freqüência temporal e imagens MODIS/TERRA para o estudo da turbidez na Planície de Curuai. In: Simpósio Brasileiro de Sensoriamento Remoto, 13. (SBSR), 2007, Florianópolis. Anais... São José dos Campos: INPE, 2007. p. 6549-6556. CD-ROM; On-line. ISBN 978-85-17-00031-7. (INPE-14680PRE/9654). Disponível em: <http://urlib.net/dpi.inpe.br/sbsr@80/2006/10.11.04.08>. Acesso em: 23 out. 2014.

ALMEIDA, C.A. Estimativa da área e do tempo de permanência da vegetação secundária na Amazônia Legal por meio de imagens Landsat/TM. 2009, 130P. Dissertação (Mestrado em Sensoriamento Remoto) - Instituto Nacional de Pesquisas Espaciais, São José dos Campos, 2008.

ARRAUT, E. M.; RUDORFF, C. M.; BARBOSA, C. C. F.; CARVALHO, J. C.; PEREIRA FILHO, W.; NOVO, E. M. L. M. Estudo do comportamento espectral da clorofila e dos sólidos em suspensão nas águas do Lago Grande de Curuai (Pará), na época da seca, através de técnicas de espectroscopia de campo. In: SIMPÓSIO BRASILEIRO DE SENSORIAMENTO REMOTO, 12. (SBSR), 2005, Goiânia. Anais... São José dos Campos: INPE, 2005. p. 2447-2454. CD-ROM, On-line. ISBN 85-17-00018-8. (INPE-12686PRE/7976). Disponível em: <http://urlib.net/ltid.inpe.br/sbsr/2004/11.18.18.48>. Acesso em: 08 fev. 2015.

BALBINOT, R.; KAMINSKI, N. de O.; VANZETTO, S.C.; PEDROSO, K. ; VALÉRIO, A.F. . O papel da floresta no ciclo hidrológico em bacias hidrográficas. Ambiência (UNICENTRO), v. 4, p. 131-149, 2008.

BARBOSA, C. C. F. Sensoriamento remoto da dinâmica de circulação da água do sistema planície de Curai/Rio Amazonas. 2005. 286 p. (INPE-14614-TDI/1193). Tese (Doutorado em Sensoriamento Remoto) - Instituto Nacional de Pesquisas Espaciais, São José dos Campos. 2005. Disponível em: <http://urlib.net/sid.inpe.br/MTCm13@80/2006/02.22.15.03>. Acesso em: 29 mar. 2015.

BERINGUIER P., DERIOZ P., LAQUES A.-E., Les paysages français, A. Colin, Synthèse, $N^{\circ} 94,1999$

BONNET, M.-P, BARROUX, G., Martinez, J.M, SEYLER, F., MOREIRA-TURCQ, P., COCHONNEAU, G., MELACK, J.M., BOAVENTURA, G., MAURICE-BOURGOIN, L., LEON, J.G., ROUX, E., CALMANT, S., GUYOT, J.L., SEYLER, P. (2008). Flooding hydrology in an Amazonian floodplain lake (Lago Grande de CuruaI), Journal of Hydrology, v. 349, n. 1-2, p. 18-30.

BROWN, S.; LUGO, A. E. Tropical Secondary Forests. 1990. Journal of Tropical Ecology, 6(1):1-32. 
COSTA, M. P. F.; TELMER, K.; NOVO, E. M. L. M. Spectral light attenuation in Amazonian waters. São José dos Campos: INPE, 2006-12-13. (INPE ePrint sid.inpe.br/ePrint@80/2006/12.12.17.56).

Disponível

em:

<http://urlib.net/sid.inpe.br/ePrint@80/2006/12.12.17.56>. Acesso em: 10 dez. 2015.

CROSTA, A. P. Processamento Digital de Imagens de Sensoriamento Remoto. Campinas: IG/UNICAMP, ISBN 85-853-690-27, 1992.

DEFFONTAINES J. P., Étude de l'activité agricole et analyse du paysage, L'Espace Géographique, 1985 / 1

EMBRAPA MONITORAMENTO POR SATÉLITE. Satélites de Monitoramento. Campinas: Embrapa Monitoramento por Satélite, 2013. Disponível em: <http://www.sat.cnpm.embrapa.br>. Acesso em: 12 nov. 2014

ESCADA, M. I. S. Evolução de padrões da terra na região centro-norte de Rondônia. 2003, 264p. Tese (Doutorado em Sensoriamento Remoto) - Instituto Nacional de Pesquisas Espaciais, São José dos Campos, 2003.

FORMAN, R.T.T. \& GODRON, M. 1986. Landscape ecology. Wiley \& Sons Ed., New York.

FREITAS, R. M.; NOVO, E. M. L. M. Mapeamento de áreas alagáveis na Planície do Rio Amazonas a partir de dados do sensor MODIS - região do Lago Curuaí - PA. In: SIMPÓSIO BRASILEIRO DE SENSORIAMENTO REMOTO, 12. (SBSR), 2005, Goiânia. Anais... São José dos Campos: INPE, 2005. p. 533-540. CD-ROM, On-line. ISBN 85-17-00018-8. (INPE12604-PRE/7897). Disponível em:<http://urlib.net/ltid.inpe.br/sbsr/2004/11.21.12.55>. Acesso em: 08 fev. 2016.

HESS, L. L.; MELACK, J. M.; NOVO, E. M. L. M.; BARBOSA, C. C.; GASTIL, M. Dualseason mapping of wetland inundation and vegetation. Remote Sensing of Environment, v. 87, p. 404-428, 2003.

INSTITUTO BRASILEIRO DE GEOGRAFIA E ESTATÍSTICA - IBGE. Base Cartográfica Digital Contínua da Amazônia Legal - BCAL, 1:100.000. Rio de Janeiro: IBGE 2013

Base de informações do Censo Demográfico 2010: resultados do universo por setor censitário. Documentação do Arquivo. Rio de Janeiro: IBGE, 2011.

Manuais técnicos em geociências: manual técnico de vegetação brasileira. Rio de Janeiro: IBGE 2012

INSTITUTO BRASILEIRO DO MEIO AMBIENTE E DOS RECURSOS NATURAIS RENOVÁVEIS - IBAMA. Diversidade socioambiental nas várzeas dos rios Amazonas e Solimões: perspectivas para o desenvolvimento da sustentabilidade. Manaus: 2005.

INSTITUTO DO HOMEM E MEIO AMBIENTE DA AMAZÔNIA - IMAZON; A floresta habitada: história da ocupação humana na Amazônia - Belém, PA:2014. 
JUNK, W. J. Ecology of the várzea, floodplain of Amazonian whitewater rivers. In: SIOLI, H. (Ed.). The Amazon - Limnology and landscape ecology of a mighty tropical river and its basin. Junk, Dordrecht, 1984.

LANDIS, J.R.; KOCH, G.G. The measurement of observer agreement for categorical data. Biometrics, 33(1):159-174, 1977.

LIZET B. et de RAVIGNAN F., Comprendre un paysage. Guide pratique de recherche, INRA, 1987

MCGARIGAL AND MARKS. Fragstats: Spatial pattern analysis program for quantifying landscape structure. Reference manual. For.Sci. Dep. Oregon State University. Corvallis Oregon. 1995. 59 p.+ Append

MARTINS, P. S. Dinâmica evolutiva em roças de caboclos amazônicos. Estudos Avançados, v. 19, n. 53, p. 209 -220,jan / abr 2005. Disponível em: http://www.scielo.br/scielo.php?pid=S010340142005000100013\&script=sci_arttext\&tlng=en. Acesso em: 02 nov 2015.

MEGONIGAL, J.P., CONNER, W.H., KROEGER, S., SHARITZ, R.R. (1997) Aboveground production in southeastern floodplain forests: a test of the subsidy-stress hypothesis. Ecology 78: 370-384.

MENESES, P.R., ALMEIDA, T. de. Introdução ao Processamento de Imagens de Sensoriamento Remoto. 1 ed. Brasília: UnB/CNPq, v.1, 2012

METZGER, J. P. O que é ecologia de paisagens? In:Biota Neotropica, v. 1, 2001.

NOVO, E. M. L. M.; AFFONSO, A. G.; MELACK, J. M. Multi-sensor approaches to assess the relationship between wetland deforestation and Amazon floodplain lake eutrophication. In: : Simpósio Brasileiro de Sensoriamento Remoto, 13. (SBSR), 2007, Florianópolis, Brasil. Anais... São José dos Campos: INPE, 2007. p. 3483-3490.

OLIVEIRA, A. E. de. Ocupação humana. In: Salati, E. et al. (Org.). Amazônia: desenvolvimento, integração e ecologia. São Paulo: Brasiliense/CNPq, p. 144-327, 1983.

PERES, L. G. M.; GURGEL, H. C.; LAQUES, A-E. O estudo da paisagem como ferramenta de análise de áreas protegidas na fronteira entre o Brasil e a França. In: Environnement et Géomatique : Approches comparées France-Brésil, 2014, Rennes. Acte du Colloque. Rennes: LETG-Rennes-COSTEL / USP, 2014. v. 1. p. 300-307.

PINHEIRO, L. C. S. J.; Análise Multitemporal do Uso e Cobertura da Terra no Município de Correntina- BA. (Dissertação de Mestrado). Curso de Pós- Graduação em Geografia, Universidade de Brasília, 2012. $66 f$

PIROVANI, D. B. ; SILVA, A. G. ; SANTOS, A. R. ; CECILIO, R. A. ; MARTINS, S. V. ; GLERIANI, J. M. . Uso de Geotecnologias Para Estudo da Fragmentação Florestal com Base em Princípios de Ecologia da Paisagem. In: Alexandre Rosa dos Santos; João Batista Esteves Peluzio; Telma Machado de Oliveira Peluzio; Gleissy Mary Amaral Dino Alves dos Santos. (Org.). Geotecnologias aplicadas aos recursos florestais. 1ed.: , 2012, v. , p. 24-42. 
PRATES, R. C.; BACHA, C. J. C. . O Processo de Desenvolvimento da Amazônia e o Seu Desmatamento. Economia e Sociedade (UNICAMP. Impresso), v. 20, p. 601-636, 2011.

RENÓ, V.F. Avaliação do desflorestamento da várzea do Baixo Amazonas com imagens Landsat obtidas em 1975/1981 e 2008. 2010, 99p. Dissertação (Mestrado em Sensoriamento Remoto) - Instituto Nacional de Pesquisas Espaciais, São José dos Campos, 2010.

RICHERS, B. T. T. Agricultura migratória em ambientes de várzea na Amazônia Central: Ameaça ou sistema integrado?. Uakari (Belém. Online), v. 6, p. 27-37, 2010.

RODRIGUES, T. E.; OLIVEIRA, R. C. Solos de várzeas da Amazônia: uso e potencialidade. In.: Amazônia: agricultura sustentável. Viçosa. Sociedade Brasileira de Ciência do Solo, 1997. p. 215-221.

SOARES FILHO, B. S. Análise da paisagem: fragmentação e mudanças. Belo Horizonte: Departamento de Cartografia, Centro de Sensoriamento remoto. Instituto de Geociências. UFMG, 02p, 1998.

TURNER, M. CARPENTER, S.:, At last: a journal devoted to ecosystems', Ecosystems 1(1), 1-4. 1998.

TRENTIN, A. B.; KRAMER, G.; BARBOSA, C. C. F.; RUDORFF, C. M.; PEREIRA FILHO, W.; NOVO, E. M. L. M. Geoestatística aplicada ao estudo da relação entre profundidade e turbidez no Lago Grande de Curuai/PA. In: SIMPÓSIO BRASILEIRO DE SENSORIAMENTO REMOTO, 14. (SBSR), 2009, Natal. Anais... São José dos Campos: INPE, 2009. p. 4505-4512. DVD, On-line. ISBN 978-85-17-00044-7. (INPE-16056PRE/10665). Disponível em: <http://urlib.net/dpi.inpe.br/sbsr@80/2008/11.17.20.10>. Acesso em: 08 fev. 2015. 


\section{CONCLUSÕES}

Uma análise das dinâmicas de uso e alteração de cobertura da terra do Bioma Amazônia, utilizando sensoriamento remoto e métricas de paisagem, pode ser um instrumento importante na compreensão desses processos e na busca de soluções que busquem mitigar os impactos que esse fenômeno trás, em especial nas regiões de várzea, ambientes frágeis e suscetíveis aos impactos de eventos climáticos extremos. Os processamentos utilizados para a elaboração da série temporal utilizando imagens TM e ETM+ mostraram-se adequados e trouxeram resultados satisfatórios conforme apresentado pelo índice Kappa. O uso das métricas de paisagem trouxe um aporte interessante que facilitou a compreensão das dinâmicas de uso e alteração através dos índices. O trabalho de campo apresentou-se fundamental para a compreensão da realidade dos ambientes naturais e das dinâmicas antrópicas, facilitando o entendimento e a elaboração das análises, principalmente por terem sido realizadas em períodos hidrológicos distintos, na cheia e na vazante.

Conforme os resultados, na bacia hidrográfica do Lago Grande do Curuai o período analisado entre 1985 e 2014 trouxe uma dinâmica moderada de substituição da cobertura vegetal natural por usos antrópicos; a principal dinâmica encontrada foi a diminuição da floresta primária e aporte de vegetação secundária, que mais que dobrou de tamanho, o que está em consonância com os processos produtivos da região, que consiste basicamente em um sistema agrícola de baixa tecnologia de culturas rotativas, que exige a abertura de novas áreas que são posteriormente abandonadas e entram em processo regenerativo. Mesmo as áreas de roça e pasto implantadas têm dimensões pequenas e encontram-se dispersas, dado evidenciado pelo pequeno tamanho médio dos fragmentos e pelo elevado número de fragmentos áreas agrícolas.

A diminuição da floresta em áreas de várzea também foi detectada em trabalhos de Hess (2003) e Renó (2010). Nas áreas de várzea a própria dinâmica natural dos regimes de cheia e seca apresenta uma vantagem para os sistemas produtivos desenvolvidos nessas regiões, pois permite a utilização dessas áreas, que são intermitentemente inundadas, para atividades agropecuárias. Isso foi apontado no trabalho de Richers (2010), que monitorou a várzea de Mamirauá, no Amazonas, encontrando padrão similar de uso e ocupação da terra.

A divisão da região de estudo em distintos recortes geográficos permitiu analisar e demonstrar a diversidade dos processos de uso da terra na região de estudo, o que ajudou a 
compreendê-los, em especial o recorte das zonas da paisagem. Nesse recorte, a associação das zonas aos sistemas produtivos ajudou a compreendê-los, associando seus usos às condições naturais e identificando uma dinâmica incipiente. Das seis zonas, duas localizadas em terra firme concentram as maiores alterações de uso e cobertura da terra. Isso demonstrou que o processo de substituição da cobertura vegetal natural é heterogêneo na região estudada.

Os resultados também podem ser utilizados em análises de qualidade da água e da circulação hidrográfica da bacia como um todo. Parte dos resultados deste trabalho foi empregado em outras pesquisas do projeto Clim-FABIAM, buscando uma correlação entre as formas de ocupação do território e o funcionamento hidrológico da bacia; essas pesquisas encontram-se em andamento. Parte dos resultados também foi apresentada às comunidades estudadas, de forma a trazer utilidade para a sociedade da pesquisa realizada, de forma a empoderar os atores locais quanto à tomada de decisões no planejamento do uso do espaço.

Torna-se importante monitorar a região estudada pelos fatores externos de pressão que podem ter acréscimo nos próximos anos. Embora a região ainda conte com um grau de preservação considerável, a bacia hidrográfica do Lago Grande do Curuai fica próxima a grandes projetos de mineração de bauxita e pode sofrer a influência do asfaltamento da BR163, em Santarém. Além disso, a presença do assentamento PAE Lago Grande na região estudada exige um monitoramento constante, para planejar os usos e evitar uma maior degradação do ambiente. Para estudos futuros em outras áreas semelhantes do bioma, recomenda-se um menor intervalo entre os anos analisados, o que não foi possível nesse estudo devido à baixa qualidade dos dados disponíveis. 


\section{REFERÊNCIAS BIBLIOGRÁFICAS}

ALCÂNTARA, E.; STECH, J. L.; BARBOSA, C. C. F.; NOVO, E. M. L. M.; SHIMABUKURO, Y. E. Integração de dados de alta freqüência temporal e imagens MODIS/TERRA para o estudo da turbidez na Planície de Curuai. In: Simpósio Brasileiro de Sensoriamento Remoto, 13. (SBSR), 2007, Florianópolis. Anais... São José dos Campos: INPE, 2007. p. 6549-6556. CD-ROM; On-line. ISBN 978-85-17-00031-7. (INPE-14680PRE/9654). Disponível em: <http://urlib.net/dpi.inpe.br/sbsr@80/2006/10.11.04.08>. Acesso em: 23 out. 2014.

BALBINOT, R.; KAMINSKI, N. de O.; VANZETTO, S.C.; PEDROSO, K. ; VALÉRIO, A.F. . O papel da floresta no ciclo hidrológico em bacias hidrográficas. Ambiência (UNICENTRO), v. 4, p. 131-149, 2008.

BARBOSA, C. C. F. Sensoriamento remoto da dinâmica de circulação da água do sistema planície de Curai/Rio Amazonas. 2005. 286 p. (INPE-14614-TDI/1193). Tese (Doutorado em Sensoriamento Remoto) - Instituto Nacional de Pesquisas Espaciais, São José dos Campos. 2005. Disponível em: <http://urlib.net/sid.inpe.br/MTCm13@80/2006/02.22.15.03>. Acesso em: 10 dez. 2015.

BECKER, B. K. Geopolítica da Amazônia: A Nova Fronteira de Recursos. Rio de Janeiro: Zahar, 1982. 233 p.

BERINGUIER P., DERIOZ P., LAQUES A.-E., Les paysages français, A. Colin, Synthèse, $\mathrm{N}^{\circ}$ 94, 1999

BOURGOIN, L. M., BONNET, M. P., MARTINEZ, J. M., KOSUTH, P., COCHONNEAU, G., MOREIRA-TURCQ, P., GUYOT, J., VAUCHEL, P., \&SEYLER, P. (2007). Temporal dynamics of water and sediment exchanges between the Curuaí floodplain and the Amazon River, Brazil Journal of Hydrology, 335(1), 140-156.

BUNKER, S. G. Os programas de crédito e a desintegração não-intencional a das economias extrativas de exportação no Médio Amazonas do Pará. Pesq. Plan. Econ., v. 12, n. 1, p. 231260, abril, 1982.

CHAVES, T. A.; CARVAlHO JUNIOR, O. A.; GOMES, R. A. T.; GUIMARÃES, R. F.; MARTINS, E. S. Padrões de Fragmentação da Paisagem no Município de Céu Azul (Paraná). Geografia Ensino \& Pesquisa, v. 19, p. 79-92, 2015.

COSTA, M. P. F.; TELMER, K.; NOVO, E. M. L. M. Spectral light attenuation in Amazonian waters. São José dos Campos: INPE, 2006-12-13. (INPE ePrint sid.inpe.br/ePrint@80/2006/12.12.17.56)._ Disponível em: <http://urlib.net/sid.inpe.br/ePrint@80/2006/12.12.17.56>. Acesso em: 10 dez. 2015.

DEFFONTAINES J. P., Étude de l'activité agricole et analyse du paysage, L'Espace Géographique, 1985 / 1 
Campinas: Embrapa Monitoramento por Satélite, 2013. Disponível em: $<$ http://www.sat.cnpm.embrapa.br>. Acesso em: 12 nov. 2014

ESCADA, M. I. S. Evolução de padrões da terra na região centro-norte de Rondônia. 2003, 264p. Tese (Doutorado em Sensoriamento Remoto) - Instituto Nacional de Pesquisas Espaciais, São José dos Campos, 2003.

FARINA, A. Principles and methods in landscape ecology. Londres: Chapman e Hall.1998., 235 p

FOLEY, J.A.; ASNER, G.P.; COSTA, M.H.; COE, M.T.; DEFRIES, R.; GIBBS, H.K.; HOWARD, E.A.; OLSON, S.; PATZ, J.; RAMANKUTTY, N. \& SNYDER, P. 2007. Amazonia revealed forest degradation and loss of ecosystem goods and services in the Amazon Basin. Frontiers in Ecology and the Environment, 5(1): 25-32.

FOLHES, R. T., AGUIAR, A. P. D., \& JUNIOR, R. A. O. S. (2012). Cenários participativos de mudanças no uso da terra na Amazônia: o caso de Vila Brasil no Projeto de Assentamento Agroextrativista do Lago Grande, PA Campo-Território: revista de geografia agrária, 7(14).

FORMAN, R.T.T. \& GODRON, M. 1986. Landscape ecology. Wiley \& Sons Ed., New York.

HESS, L. L.; MELACK, J. M.; NOVO, E. M. L. M.; BARBOSA, C. C.; GASTIL, M. Dualseason mapping of wetland inundation and vegetation. Remote Sensing of Environment, v. 87, p. 404-428, 2003.

INSTITUTO BRASILEIRO DE GEOGRAFIA E ESTATÍSTICA - IBGE. Mapa de Biomas do Brasil, primeira aproximação. Rio de Janeiro: IBGE (2004).

Base de informações do Censo Demográfico 2010: resultados do universo por setor censitário. Documentação do Arquivo. Rio de Janeiro: IBGE, 2011.

INSTITUTO BRASILEIRO DO MEIO AMBIENTE E DOS RECURSOS NATURAIS RENOVÁVEIS - IBAMA. Diversidade socioambiental nas várzeas dos rios Amazonas e Solimões: perspectivas para o desenvolvimento da sustentabilidade. Manaus: 2005.

INSTITUTO DO HOMEM E MEIO AMBIENTE DA AMAZÔNIA - IMAZON; A floresta habitada: história da ocupação humana na Amazônia - Belém, PA:2014.

INSTITUTO NACIONAL DE PESQUISAS ESPACIAIS - INPE. Projeto PRODES. Monitoramento da Floresta Amazônica Brasileira por Imagens de Satélite. Disponível em: http://www.obt.inpe.br/prodes/prodes_1988_2015.htm. Acesso em 29 de out. de 2015.

Uso e cobertura da terra nas áreas desflorestadas da Amazônia Legal :

TerraClass 2008 - Belém, 2013.

JUNK, W. J. Ecology of the várzea, floodplain of Amazonian whitewater rivers. In: SIOLI, H. (Ed.). The Amazon - Limnology and landscape ecology of a mighty tropical river and its basin. Junk, Dordrecht, 1984. 
Os recursos hídricos da Amazônia. In: Pavan, C.; Araújo, M. C. d. (Eds.). Uma estratégia latino-americana para a Amazônia. v. 3. Brasília, Brasil: Ministério do Meio Ambiente, dos Recursos Hídricos e da Amazônia Legal 1996, p. 247-259.

KIEL, R. Deteç̧ão de mudanças no uso e na cobertura do solo em uma série temporal de imagens da região de campanha do Rio Grande do Sul. 2008. 203 f. Dissertação

(Mestrado em Sensoriamento Remoto) - Universidade Federal do Rio Grande do Sul, Porto Alegre, 2008.

LAQUES, A. E. Dynamique d'um front pionnier em Domaine Forestier tropical: le cas de Ticoporo (Piémont des Andes Venezueliennnes). 1993 Tese de Doutorado. Université de Toulouse. Toulouse, França, 1993

LIMA, A. G.; A bacia hidrográfica como recorte de estudos em Geografia Humana. Geografia (Londrina), v. 14, p. 173-183, 2005.

LIMA, R. N. S.; ROCHA, C. H. B. Técnicas de sensoriamento remoto e métricas de ecologia da paisagem aplicadas na análise da fragmentação florestal no município de Juiz de Fora MG em 1987 e 2008. In: SIMPÓSIO BRASILEIRO DE SENSORIAMENTO REMOTO, 15. (SBSR)., 2011, Curitiba. Anais... São José dos Campos: INPE, 2011. p. 2067-2074. DVD, Internet. ISBN 978-85-17-00056-0 (Internet), 978-85-17-00057-7 (DVD). Disponível em: <http://urlib.net/3ERPFQRTRW/3A54QCL>. Acesso em: 08 fev. 2015.

LIZET B. et de RAVIGNAN F., Comprendre un paysage. Guide pratique de recherche, INRA, 1987

LUCAS, Y., 1989. Systèmes pédologiques em Amazonie brésilienne. Equilibres, déséquilibres et transformations. PhD Dissertation, Univ. de Poitiers France.

MCGARIGAL AND MARKS. Fragstats: Spatial pattern analysis program for quantifying landscape structure. Reference manual. For.Sci. Dep. Oregon State University. Corvallis Oregon. 1995. 59 p.+ Append

MATTOS, J. C. F.; CARVALHO JUNIOR, O. A.; GUIMARAES, R. F. Ecologia da Paisagem voltada para o manejo de avifauna. IN: Revista Espaço e Geografia. Brasília: DF, Departamento de Geografia, UnB, v. 6, p. 92-105 2003.

MEGONIGAL, J.P., CONNER, W.H., KROEGER, S., SHARITZ, R.R. (1997) Aboveground production in southeastern floodplain forests: a test of the subsidy-stress hypothesis. Ecology 78: 370-384.

MELACK, J. M., \& HESS, L. L. (2011). Remote sensing of the distribution and extent of wetlands in the Amazon basin. In Amazonian floodplain forests (pp. 43-59). Springer Netherlands.

METZGER, J. P. O que é ecologia de paisagens? In:Biota Neotropica, v. 1, 2001.

NEPSTAD, D.C. et.al. "Large scale improverishment of Amazonian forests by logging and fire”. Nature, v.398, n.6727, p.505-508. 1999.

NOBRE, A. D. O futuro climático da Amazônia: relatório de avaliação científica. -São 
José dos Campos, SP: ARA: CCST-INPE: INPA, 2014

NOBRE, C.A., “Amazônia: fonte ou sumidouro de carbono?” Em: Causas e dinâmica do desmatamento na Amazônia. Ministério do Meio Ambiente, p.197-224. 2001.

PAROLIN, P. Growth, productivity and use of trees in white water floodplains. In: Junk, W. J.; Ohly, J. J.; Piedade, M. T. F.; Soares, M. G. M. (Eds.). The central Amazon floodplain: actual use and options for a sustainable management. Leiden, The Netherlands: Blackhuys Publishers, 2002, p. 375-391.

PERES, L. G. M.; GURGEL, H. C.; LAQUES, A-E. O estudo da paisagem como ferramenta de análise de áreas protegidas na fronteira entre o Brasil e a França. In: Environnement et Géomatique : Approches comparées France-Brésil, 2014, Rennes. Acte du Colloque. Rennes: LETG-Rennes-COSTEL / USP, 2014. v. 1. p. 300-307.

PINHEIRO, L. C. S. J.; Análise Multitemporal do Uso e Cobertura da Terra no Município de Correntina- BA. (Dissertação de Mestrado). Curso de Pós- Graduação em Geografia, Universidade de Brasília, 2012. 66f

PIROVANI, D. B. ; SILVA, A. G. ; SANTOS, A. R. ; CECILIO, R. A. ; MARTINS, S. V. ; GLERIANI, J. M. . Uso de Geotecnologias Para Estudo da Fragmentação Florestal com Base em Princípios de Ecologia da Paisagem. In: Alexandre Rosa dos Santos; João Batista Esteves Peluzio; Telma Machado de Oliveira Peluzio; Gleissy Mary Amaral Dino Alves dos Santos. (Org.). Geotecnologias aplicadas aos recursos florestais. 1ed.: , 2012, v. , p. 24-42.

RODRIGUES, T. E.; OLIVEIRA, R. C. Solos de várzeas da Amazônia: uso e potencialidade. In.: Amazônia: agricultura sustentável. Viçosa. Sociedade Brasileira de Ciência do Solo, 1997. p. 215-221.

RENÓ, V.F. Avaliação do desflorestamento da várzea do Baixo Amazonas com imagens Landsat obtidas em 1975/1981 e 2008. 2010, 99P. Dissertação (Mestrado em Sensoriamento Remoto) - Instituto Nacional de Pesquisas Espaciais, São José dos Campos, 2010.

SAITO, É. A.; FONSECA, L. M. G. ; ESCADA, M. I. S. ; KORTING, T. S. . Efeitos Da Mudança De Escala Em Padrões De Desmatamento Na Amazônia. RBC. Revista Brasileira de Cartografia (Online), 2011

SAMPAIO, G.; NOBRE, C.A.; COSTA, M.H.; SATYAMURTY, P.; SOARES-FILHO, B.S. \& CARDOSO, M. 2007. Regional climate change over eastern Amazonia caused by pasture and soybean cropland expansion. Geophysical Research Letters, 34: L17709, doi:10.1029/2007GL030612.

SHIMABUKuRO, Y. E. et al. Detecção de Áreas Desflorestadas em Tempo Real: Conceitos Básicos, Desenvolvimento e Aplicação do Projeto. Instituto Nacional de Pesquisas Espaciais, São José dos Campos, 2005, 63 p

SILVA, E.; ZAMPIERI, S. L.; LOCH, C. Paisagem: regressão e prognose como elementos para avaliação da ocupação e mudanças do espaço rural. Universidade Federal de Santa 
Catarina, 1998. Disponível em: <http://www.cartografia.org.Br/xixcbcc/artigos/c5/cv10/cv10-99a.pdf>. Acesso em: 25 jan. 2015.

SOARES FILHO, B. S. Análise da paisagem: fragmentação e mudanças. Belo Horizonte: Departamento de Cartografia, Centro de Sensoriamento remoto. Instituto de Geociências. UFMG, 02p, 1998.

SOUZA, M. L. - Os conceitos fundamentais da pesquisa sócio-espacial . 1 ed. - Rio de Janeiro: Bertrand Brasil, 2013. 320 p.

TEIXEIRA, G. Amazônia, estado, exclusão social e devastação. [S.l.:s.n.], 1998.

TURNER, M. CARPENTER, S.:, At last: a journal devoted to ecosystems', Ecosystems 1(1), 1-4. 1998.

WITTMANN, F.; JUNK, W. J.; PIEDADE, M. T. F. The várzea forests in Amazonia: flooding and the highly dynamic geomorphology interact with natural forest succession. Forest Ecology and Management, v. 196, n. 2-3, p. 199-212, 2004. Acesso em: 26 dez. 2015. 
ANEXO A: Matriz de confusão comparando os resultados da classificação (linhas) com os dados de referência de campo (colunas) - 1985

\begin{tabular}{|c|c|c|c|c|c|}
\hline \multirow{2}{*}{\multicolumn{2}{|c|}{$\begin{array}{l}\text { Classificação da } \\
\text { Várzea }\end{array}$}} & \multicolumn{3}{|c|}{ Referência de Campo } & \multirow{3}{*}{$\begin{array}{c}\begin{array}{c}\text { Total da } \\
\text { Classe }\end{array} \\
\mathbf{2 9}\end{array}$} \\
\hline & & \multirow{2}{*}{$\begin{array}{c}\begin{array}{c}\text { Floresta de } \\
\text { Várzea }\end{array} \\
21\end{array}$} & \multirow{2}{*}{$\begin{array}{c}\text { Hidrografia } \\
0\end{array}$} & \multirow{2}{*}{$\begin{array}{c}\begin{array}{c}\text { Pasto } \\
\text { Natural }\end{array} \\
8\end{array}$} & \\
\hline \multirow{4}{*}{ 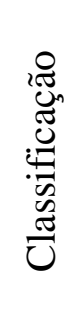 } & $\begin{array}{c}\text { Floresta de } \\
\text { Várzea }\end{array}$ & & & & \\
\hline & Hidrografia & 0 & 20 & 0 & 20 \\
\hline & $\begin{array}{c}\text { Pasto } \\
\text { Natural }\end{array}$ & 0 & 0 & 51 & 51 \\
\hline & Total & 21 & 20 & 39 & 100 \\
\hline
\end{tabular}

\begin{tabular}{|c|c|c|c|c|c|c|c|c|}
\hline \multirow{2}{*}{\multicolumn{2}{|c|}{$\begin{array}{c}\text { Classificação da Terra } \\
\text { Firme }\end{array}$}} & \multicolumn{6}{|c|}{ Referência de Campo } & \multirow{3}{*}{\begin{tabular}{|c|}
$\begin{array}{l}\text { Total da } \\
\text { Classe }\end{array}$ \\
7
\end{tabular}} \\
\hline & & \multirow{2}{*}{$\begin{array}{c}\text { Área Urbana } \\
6\end{array}$} & \multirow{2}{*}{$\begin{array}{c}\text { Campo } \\
\text { Natural } \\
\text { (Cerrado) }\end{array}$} & \multirow{2}{*}{$\begin{array}{c}\text { Pasto } \\
1 \\
\end{array}$} & \multirow{2}{*}{$\begin{array}{c}\text { Roça } \\
0 \\
\end{array}$} & \multirow{2}{*}{$\begin{array}{c}\begin{array}{c}\text { Floresta } \\
\text { de Terra } \\
\text { Firme }\end{array} \\
0\end{array}$} & \multirow{2}{*}{$\begin{array}{c}\text { Vegetação } \\
\text { Secundária } \\
0\end{array}$} & \\
\hline \multirow{7}{*}{ 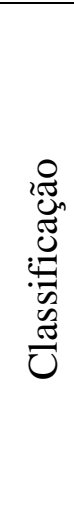 } & Área Urbana & & & & & & & \\
\hline & Campo Natural & 0 & 11 & 0 & 0 & 0 & 0 & 11 \\
\hline & Pasto & 0 & 0 & 10 & 0 & 1 & 0 & 11 \\
\hline & Roça & 2 & 0 & 3 & 15 & 1 & 0 & 21 \\
\hline & $\begin{array}{c}\text { Floresta de Terra } \\
\text { Firme }\end{array}$ & 1 & 0 & 0 & 1 & 21 & 4 & 27 \\
\hline & $\begin{array}{l}\text { Vegetação } \\
\text { Secundária }\end{array}$ & 2 & 1 & 7 & 0 & 0 & 13 & 23 \\
\hline & Total & 11 & 12 & 21 & 16 & 23 & 17 & 100 \\
\hline
\end{tabular}




\begin{tabular}{|c|c|c|c|c|c|}
\hline \multirow{2}{*}{\multicolumn{2}{|c|}{$\begin{array}{c}\text { Classificação da } \\
\text { Várzea }\end{array}$}} & \multicolumn{3}{|c|}{ Referência de Campo } & \multirow{3}{*}{$\begin{array}{c}\begin{array}{c}\text { Total da } \\
\text { Classe }\end{array} \\
22\end{array}$} \\
\hline & & Floresta de Várzea & Hidrografia & Pasto & \\
\hline \multirow{4}{*}{ 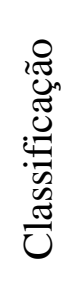 } & $\begin{array}{c}\text { Floresta de } \\
\text { Várzea }\end{array}$ & 19 & 0 & 3 & \\
\hline & Hidrografia & 0 & 27 & 0 & 27 \\
\hline & Pasto Natural & 5 & 1 & 45 & 51 \\
\hline & Total & 24 & 28 & 48 & 100 \\
\hline
\end{tabular}

\begin{tabular}{|c|c|c|c|c|c|c|c|c|}
\hline \multirow{2}{*}{\multicolumn{2}{|c|}{$\begin{array}{c}\text { Classificação da Terra } \\
\text { Firme }\end{array}$}} & \multicolumn{6}{|c|}{ Referência de Campo } & \multirow{3}{*}{\begin{tabular}{|c|}
$\begin{array}{l}\text { Total da } \\
\text { Classe }\end{array}$ \\
$\mathbf{8}$ \\
\end{tabular}} \\
\hline & & \multirow{2}{*}{$\begin{array}{c}\text { Área Urbana } \\
6 \\
\end{array}$} & \multirow{2}{*}{$\begin{array}{c}\begin{array}{c}\text { Campo } \\
\text { Natural } \\
\text { (Cerrado) }\end{array} \\
1 \\
\end{array}$} & \multirow{2}{*}{$\begin{array}{c}\text { Pasto } \\
1 \\
\end{array}$} & \multirow{2}{*}{$\begin{array}{c}\text { Roça } \\
0 \\
\end{array}$} & \multirow{2}{*}{$\begin{array}{c}\begin{array}{c}\text { Floresta } \\
\text { de Terra } \\
\text { Firme }\end{array} \\
0 \\
\end{array}$} & \multirow{2}{*}{$\begin{array}{c}\text { Vegetação } \\
\text { Secundária } \\
0 \\
\end{array}$} & \\
\hline \multirow{7}{*}{ 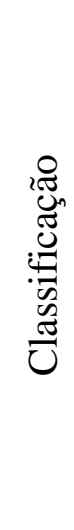 } & Área Urbana & & & & & & & \\
\hline & Campo Natural & 0 & 13 & 0 & 0 & 0 & 0 & 13 \\
\hline & Pasto & 0 & 0 & 20 & 1 & 0 & 0 & 21 \\
\hline & Roça & 0 & 0 & 0 & 17 & 0 & 1 & 18 \\
\hline & $\begin{array}{l}\text { Floresta de Terra } \\
\text { Firme }\end{array}$ & 0 & 0 & 0 & 0 & 23 & 9 & 32 \\
\hline & $\begin{array}{l}\text { Vegetação } \\
\text { Secundária }\end{array}$ & 1 & 0 & 0 & 2 & 2 & 4 & 9 \\
\hline & Total & 7 & 14 & 21 & 20 & 25 & 14 & 101 \\
\hline
\end{tabular}


ANEXO C: Matriz de confusão comparando os resultados da classificação (linhas) com os dados de referência de campo (colunas) - 2014

\begin{tabular}{|c|c|c|c|c|c|}
\hline \multirow{2}{*}{\multicolumn{2}{|c|}{$\begin{array}{l}\text { Classificação da } \\
\text { Várzea }\end{array}$}} & \multicolumn{3}{|c|}{ Referência de Campo } & \multirow{3}{*}{$\begin{array}{c}\text { Total da } \\
\text { Classe } \\
\mathbf{2 6}\end{array}$} \\
\hline & & \multirow{2}{*}{\begin{tabular}{|c|} 
Floresta de Várzea \\
25
\end{tabular}} & \multirow{2}{*}{\begin{tabular}{|c} 
Hidrografia \\
0
\end{tabular}} & \multirow{2}{*}{$\begin{array}{l}\text { Pasto } \\
\text { Natural } \\
1\end{array}$} & \\
\hline 2: & $\begin{array}{l}\text { Floresta de } \\
\text { Várzea }\end{array}$ & & & & \\
\hline$\underbrace{}_{0}$ & Hidrografia & 0 & 26 & 0 & 26 \\
\hline प्र & Pasto Natural & 1 & 0 & 49 & 50 \\
\hline$\widetilde{U}$ & Total & 26 & 26 & 50 & 102 \\
\hline
\end{tabular}

\begin{tabular}{|c|c|c|c|c|c|c|c|c|}
\hline \multirow{2}{*}{\multicolumn{2}{|c|}{$\begin{array}{c}\text { Classificação da Terra } \\
\text { Firme }\end{array}$}} & \multicolumn{6}{|c|}{ Referência de Campo } & \multirow{3}{*}{$\begin{array}{c}\text { Total da } \\
\text { Classe } \\
\\
\mathbf{9}\end{array}$} \\
\hline & & \multirow{2}{*}{$\begin{array}{c}\text { Área Urbana } \\
9\end{array}$} & \multirow{2}{*}{$\begin{array}{c}\text { Campo } \\
\text { Natural } \\
\text { (Cerrado) }\end{array}$} & \multirow{2}{*}{$\begin{array}{c}\text { Pasto } \\
0\end{array}$} & \multirow{2}{*}{$\begin{array}{c}\text { Roça } \\
0\end{array}$} & \multirow{2}{*}{\begin{tabular}{|c}
$\begin{array}{c}\text { Floresta } \\
\text { de Terra } \\
\text { Firme }\end{array}$ \\
0
\end{tabular}} & \multirow{2}{*}{$\begin{array}{c}\text { Vegetação } \\
\text { Secundária }\end{array}$} & \\
\hline \multirow{7}{*}{ 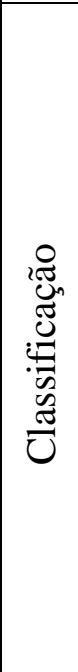 } & Área Urbana & & & & & & & \\
\hline & Campo Natural & 0 & 31 & 0 & 0 & 0 & 0 & 31 \\
\hline & Pasto & 1 & 0 & 21 & 0 & 0 & 1 & 23 \\
\hline & Roça & 0 & 1 & 0 & 23 & 0 & 0 & 24 \\
\hline & $\begin{array}{c}\text { Floresta de Terra } \\
\text { Firme }\end{array}$ & 0 & 0 & 0 & 0 & 22 & 5 & 27 \\
\hline & $\begin{array}{l}\text { Vegetação } \\
\text { Secundária }\end{array}$ & 0 & 0 & 0 & 0 & 7 & 10 & 17 \\
\hline & Total & 10 & 32 & 21 & 23 & 29 & 16 & 131 \\
\hline
\end{tabular}


ANEXO D: Métricas da paisagem aplicadas no recorte geográfico da bacia

\begin{tabular}{|c|c|c|c|c|c|c|c|c|c|}
\hline \multirow{2}{*}{ Nome da Classe } & \multicolumn{3}{|c|}{ CA } & \multicolumn{3}{c|}{ NUMP } & \multicolumn{3}{c|}{ MPS } \\
\hline & & $\mathbf{1 9 9 7}$ & $\mathbf{2 0 1 4}$ & $\mathbf{1 9 8 5}$ & $\mathbf{1 9 9 7}$ & $\mathbf{2 0 1 4}$ & $\mathbf{1 9 8 5}$ & $\mathbf{1 9 9 7}$ & $\mathbf{2 0 1 4}$ \\
\hline Área Urbana & 168,63 & 218,62 & 724,55 & 48 & 113 & 185 & 3,47 & 1,93 & 3,92 \\
\hline Campo Natural (Cerrado) & $2.241,36$ & $2.138,67$ & $2.174,09$ & 398 & 388 & 375 & 5,63 & 5,51 & 5,80 \\
\hline Floresta de Terra Firme & $86.879,03$ & $83.016,39$ & $58.277,71$ & 1.366 & 2.645 & 3.479 & 63,60 & 22,03 & 16,75 \\
\hline Floresta de Várzea & $26.906,20$ & $37.573,51$ & $53.943,18$ & 3.266 & 3.282 & 2.367 & 8,24 & 11,45 & 22,79 \\
\hline Pasto & $12.144,99$ & $9.640,67$ & $16.136,17$ & 3.764 & 3.931 & 4.099 & 3,23 & 2,45 & 3,94 \\
\hline Pasto Natural & $112.017,24$ & $101.433,59$ & $85.408,58$ & 8.413 & 7.238 & 6.302 & 13,31 & 14,01 & 13,55 \\
\hline Roça & $4.419,59$ & $5.669,56$ & $4.388,67$ & 4.762 & 6.042 & 4.244 & 0,93 & 0,94 & 1,03 \\
\hline Vegetação Secundária & $16.672,73$ & $21.756,76$ & $40.394,82$ & 5.726 & 7.093 & 4.976 & 2,91 & 3,07 & 8,12 \\
\hline
\end{tabular}


ANEXO E: Métricas da paisagem aplicadas no recorte geográfico das zonas da paisagem

\begin{tabular}{|c|c|c|c|c|c|c|c|c|c|c|}
\hline \multirow{4}{*}{$\begin{array}{c}\text { PAISAGEM } 1 \\
\text { Zona da Paisagem do } \\
\text { Sistema Pastoral da } \\
\text { Várzea Alta }\end{array}$} & & \multicolumn{3}{|c|}{ CA } & \multicolumn{3}{|c|}{ NUMP } & \multicolumn{3}{|c|}{ MPS } \\
\hline & & 1985 & 1997 & 2014 & 1985 & 1997 & 2014 & 1985 & 1997 & 2014 \\
\hline & Floresta de Varzea & $8.178,57$ & $9.891,05$ & $15.026,60$ & 1.434 & 1.654 & 1.138 & 5,70 & 5,98 & 13,19 \\
\hline & Pasto Natural & $47.285,93$ & $45.573,45$ & $40.437,90$ & 3.786 & 3.037 & 2.799 & 12,49 & 15,01 & 14,45 \\
\hline \multirow{4}{*}{$\begin{array}{c}\text { PAISAGEM } 2 \\
\text { Zona da Paisagem do } \\
\text { Sistema Pastoral da } \\
\text { Várzea Baixa }\end{array}$} & & \multicolumn{3}{|c|}{ CA } & \multicolumn{3}{|c|}{ NUMP } & \multicolumn{3}{|c|}{ MPS } \\
\hline & & 1985 & 1997 & 2014 & 1985 & 1997 & 2014 & 1985 & 1997 & 2014 \\
\hline & Floresta de Varzea & $18.727,63$ & $27.682,46$ & $38.916,58$ & 1.832 & 1.628 & 1.229 & 10,22 & 17,00 & 31,67 \\
\hline & Pasto Natural & $62.675,17$ & $53.720,34$ & $42.486,20$ & 4.188 & 4.201 & 3.503 & 14,97 & 12,79 & 12,13 \\
\hline \multirow{9}{*}{$\begin{array}{c}\text { PAISAGEM } 3 \\
\text { Zona da Paisagem do } \\
\text { Sistema Agro-Pastoral } \\
\text { de Terra Firme }\end{array}$} & & \multicolumn{3}{|c|}{ CA } & \multicolumn{3}{|c|}{ NUMP } & \multicolumn{3}{|c|}{ MPS } \\
\hline & & 1985 & 1997 & 2014 & 1985 & 1997 & 2014 & 1985 & 1997 & 2014 \\
\hline & Area Urbana & 166,63 & 218,62 & 724,55 & 48 & 113 & 185 & 3,47 & 1,93 & 3,92 \\
\hline & \begin{tabular}{|l|} 
Campo Natural \\
(Cerrado)
\end{tabular} & 119,49 & 117,99 & 117,70 & 175 & 168 & 159 & 0,68 & 0,70 & 0,74 \\
\hline & Floresta de Terra Firme & $62.987,36$ & $59.519,77$ & $37.512,10$ & 1.056 & 2.221 & 2.879 & 59,65 & 26,80 & 13,03 \\
\hline & Pasto & $10.879,17$ & $9.312,75$ & $15.257,00$ & 3.168 & 3.315 & 3.629 & 3,43 & 2,81 & 4,20 \\
\hline & Pasto Natural & $2.056,14$ & $2.139,80$ & $2.484,48$ & 439 & 546 & 507 & 4,68 & 3,91 & 4,90 \\
\hline & Roça & $3.877,31$ & $4.826,55$ & $3.827,52$ & 4.042 & 5.170 & 3.614 & 0,96 & 0,93 & 1,06 \\
\hline & Vegetação Secundária & $14.645,40$ & $18.596,02$ & $34.808,20$ & 4.514 & 5.790 & 3.649 & 3,24 & 3,21 & 9,54 \\
\hline
\end{tabular}




\begin{tabular}{|c|c|c|c|c|c|c|c|c|c|c|}
\hline \multirow{6}{*}{$\begin{array}{c}\text { PAISAGEM } 4 \\
\text { Zona da Paisagem do } \\
\text { Sistema Agro-Florestal } \\
\text { de Terra Firme }\end{array}$} & & \multicolumn{3}{|c|}{ CA } & \multicolumn{3}{|c|}{ NUMP } & \multicolumn{3}{|c|}{ MPS } \\
\hline & & 1985 & 1997 & 2014 & 1985 & 1997 & 2014 & 1985 & 1997 & 2014 \\
\hline & Floresta de Terra Firme & $14.456,89$ & $14.320,65$ & $11.931,71$ & 114 & 183 & 262 & 126,81 & 78,25 & 45,54 \\
\hline & Pasto & 479,73 & 274,57 & 792,69 & 245 & 174 & 383 & 1,96 & 1,58 & 2,07 \\
\hline & Roça & 206,98 & 284,95 & 254,79 & 284 & 363 & 347 & 0,73 & 0,78 & 0,73 \\
\hline & Vegetação Secundária & 915,71 & $1.179,14$ & $3.080,09$ & 734 & 695 & 865 & 2,47 & 1,70 & 3,56 \\
\hline \multirow{7}{*}{$\begin{array}{c}\text { PAISAGEM } 5 \\
\text { Zona da Paisagem do } \\
\text { Sistema de Floresta de } \\
\text { Terra Firme }\end{array}$} & & \multicolumn{3}{|c|}{ CA } & \multicolumn{3}{|c|}{ NUMP } & \multicolumn{3}{|c|}{ MPS } \\
\hline & & 1985 & 1997 & 2014 & 1985 & 1997 & 2014 & 1985 & 1997 & 2014 \\
\hline & $\begin{array}{l}\text { Campo Natural } \\
\text { (Cerrado) } \\
\end{array}$ & $2.121,87$ & $2.020,68$ & $2.056,39$ & 223 & 220 & 216 & 9,52 & 9,18 & 9,52 \\
\hline & Floresta de Terra Firme & $2.000,56$ & $1.900,35$ & $1.729,56$ & 130 & 157 & 232 & 15,39 & 12,10 & 7,46 \\
\hline & Pasto & 785,32 & 53,26 & 52,98 & 343 & 427 & 54 & 2,29 & 0,12 & 0,98 \\
\hline & Roça & 325,68 & 552,58 & 290,33 & 391 & 497 & 253 & 0,83 & 1,11 & 1,15 \\
\hline & Vegetação Secundária & 998,54 & $1.705,10$ & $2.102,71$ & 296 & 360 & 171 & 3,37 & 4,74 & 12,30 \\
\hline \multirow{6}{*}{$\begin{array}{c}\text { PAISAGEM } 6 \\
\text { Zona da Paisagem do } \\
\text { Ecossistema de Savana } \\
\text { de Terra Firme }\end{array}$} & & \multicolumn{3}{|c|}{ CA } & \multicolumn{3}{|c|}{ NUMP } & \multicolumn{3}{|c|}{ MPS } \\
\hline & & 1985 & 1997 & 2014 & 1985 & 1997 & 2014 & 1985 & 1997 & 2014 \\
\hline & Floresta de Terra Firme & $7.434,22$ & $7.275,62$ & $7.104,34$ & 66 & 84 & 106 & 112,64 & 86,61 & 67,02 \\
\hline & Pasto & 0,77 & 0,09 & 33,50 & 8 & 15 & 33 & 0,10 & 0,01 & 1,02 \\
\hline & Roça & 9,62 & 5,48 & 16,03 & 45 & 12 & 30 & 0,21 & 0,18 & 0,53 \\
\hline & Vegetação Secundária & 113,08 & 276,50 & 403,82 & 182 & 248 & 291 & 0,62 & 1,11 & 1,39 \\
\hline
\end{tabular}


ANEXO F: TABULAÇÃO CRUZADA 1985-1997

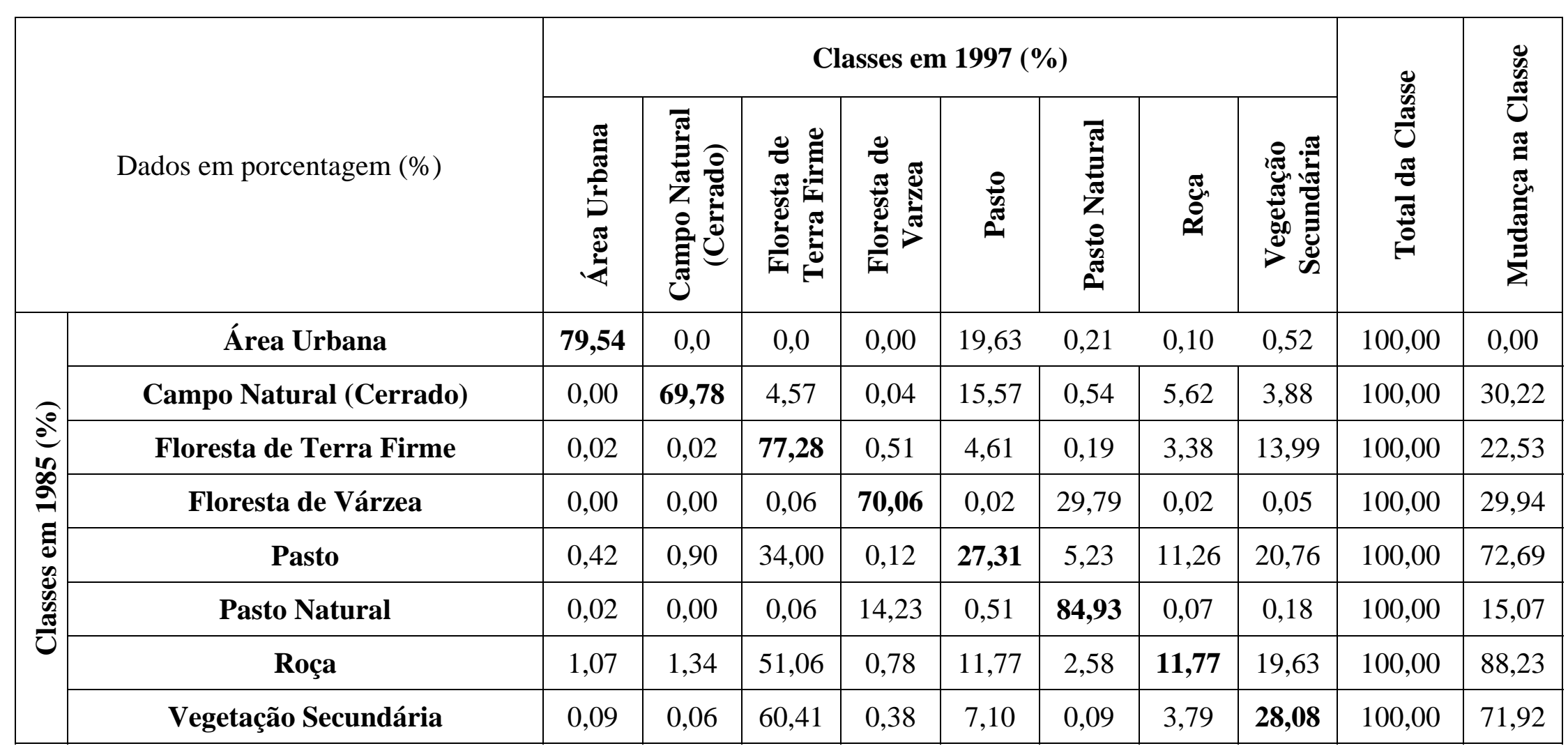


ANEXO G: TABULAÇÃO CRUZADA 1997-2011

\begin{tabular}{|c|c|c|c|c|c|c|c|c|c|c|c|}
\hline \multirow{2}{*}{ (1) } & \multirow{2}{*}{ Dados em porcentagem (\%) } & \multicolumn{8}{|c|}{ Classes em $2014(\%)$} & \multirow[b]{2}{*}{ 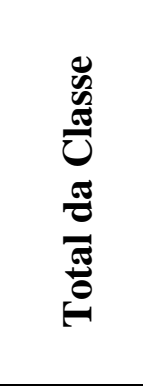 } & \multirow[b]{2}{*}{ 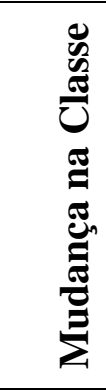 } \\
\hline & & 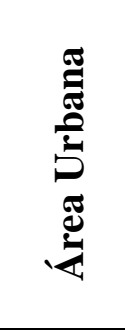 & 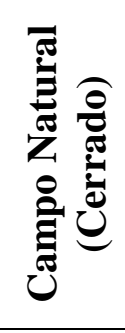 & 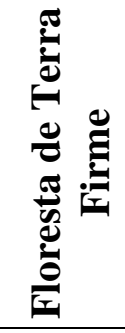 & 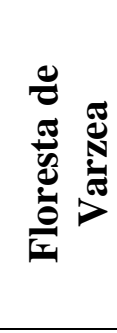 & 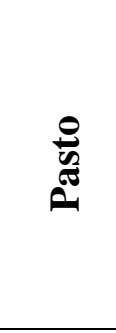 & 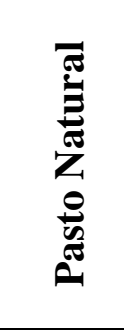 & 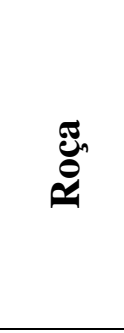 & 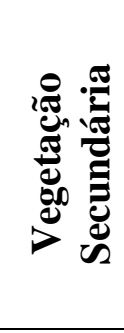 & & \\
\hline \multirow{8}{*}{ 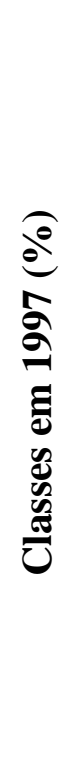 } & Área Urbana & 98,24 & 0,04 & 0,29 & 1,09 & 0,32 & 0,02 & 0,00 & 0,00 & 100,00 & 1,76 \\
\hline & Campo Natural (Cerrado) & 0,00 & 90,46 & 2,50 & 0,00 & 0,87 & 0,02 & 1,38 & 4,77 & 100,00 & 9,54 \\
\hline & Floresta de Terra Firme & 0,12 & 0,12 & 59,48 & 0,02 & 7,74 & 0,10 & 2,31 & 30,11 & 100,00 & 40,52 \\
\hline & Floresta de Várzea & 0,00 & 0,00 & 0,43 & 73,24 & 0,06 & 25,31 & 0,07 & 0,89 & 100,00 & 26,76 \\
\hline & Pasto & 2,16 & 3,65 & 12,69 & 0,05 & 44,32 & 6,94 & 7,40 & 22,79 & 100,00 & 55,68 \\
\hline & Pasto Natural & 0,01 & 0,01 & 0,00 & 23,14 & 0,65 & 76,10 & 0,07 & 0,02 & 100,00 & 23,90 \\
\hline & Roça & 0,74 & 2,90 & 29,62 & 0,16 & 22,92 & 1,10 & 14,74 & 27,82 & 100,00 & 85,26 \\
\hline & Vegetação Secundária & 0,62 & 0,69 & 28,74 & 0,05 & 14,95 & 0,78 & 3,19 & 50,98 & 100,00 & 49,02 \\
\hline
\end{tabular}




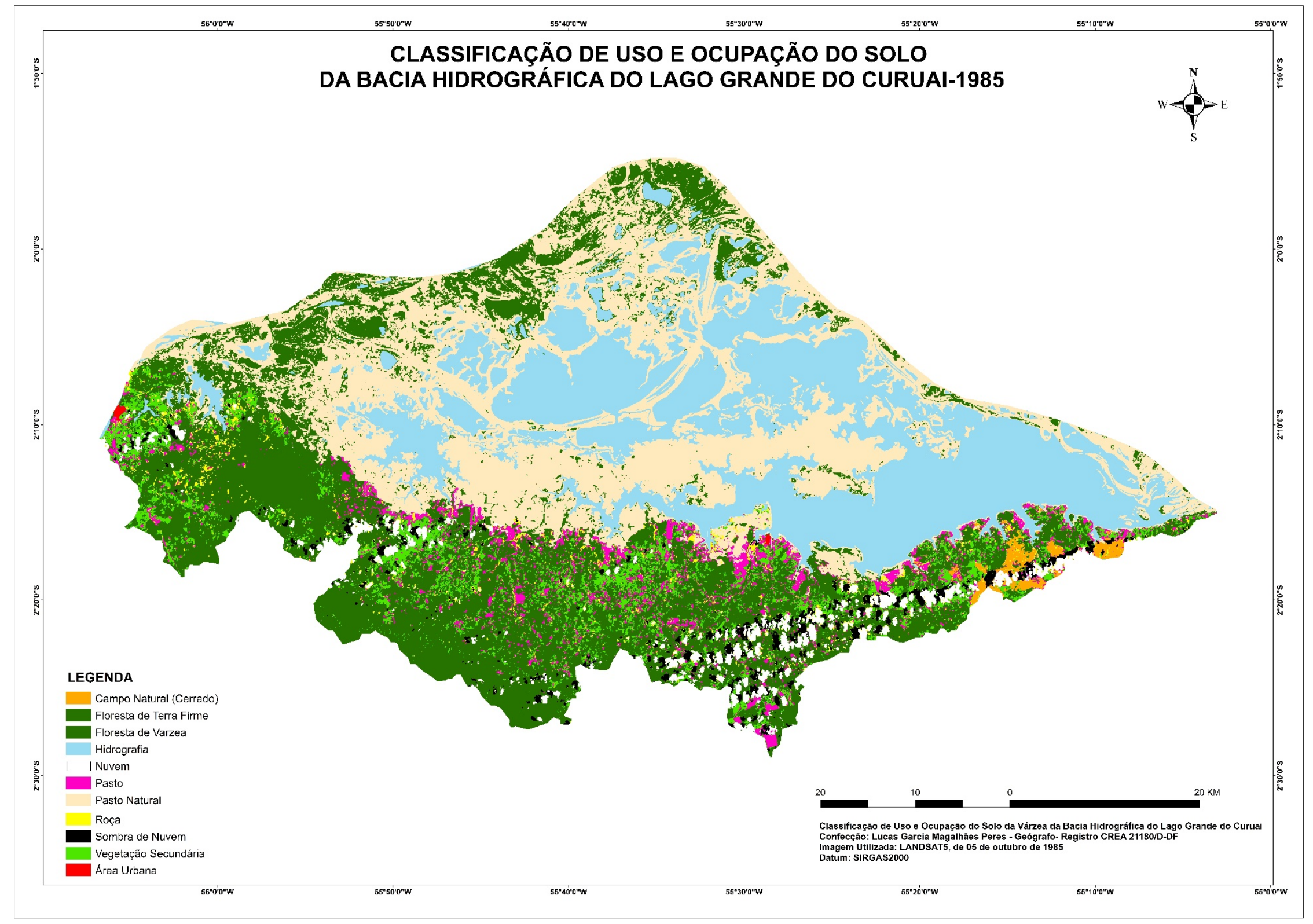

ANEXO H: Mapa de Classificação de Uso e Cobertura do Solo - 1985 


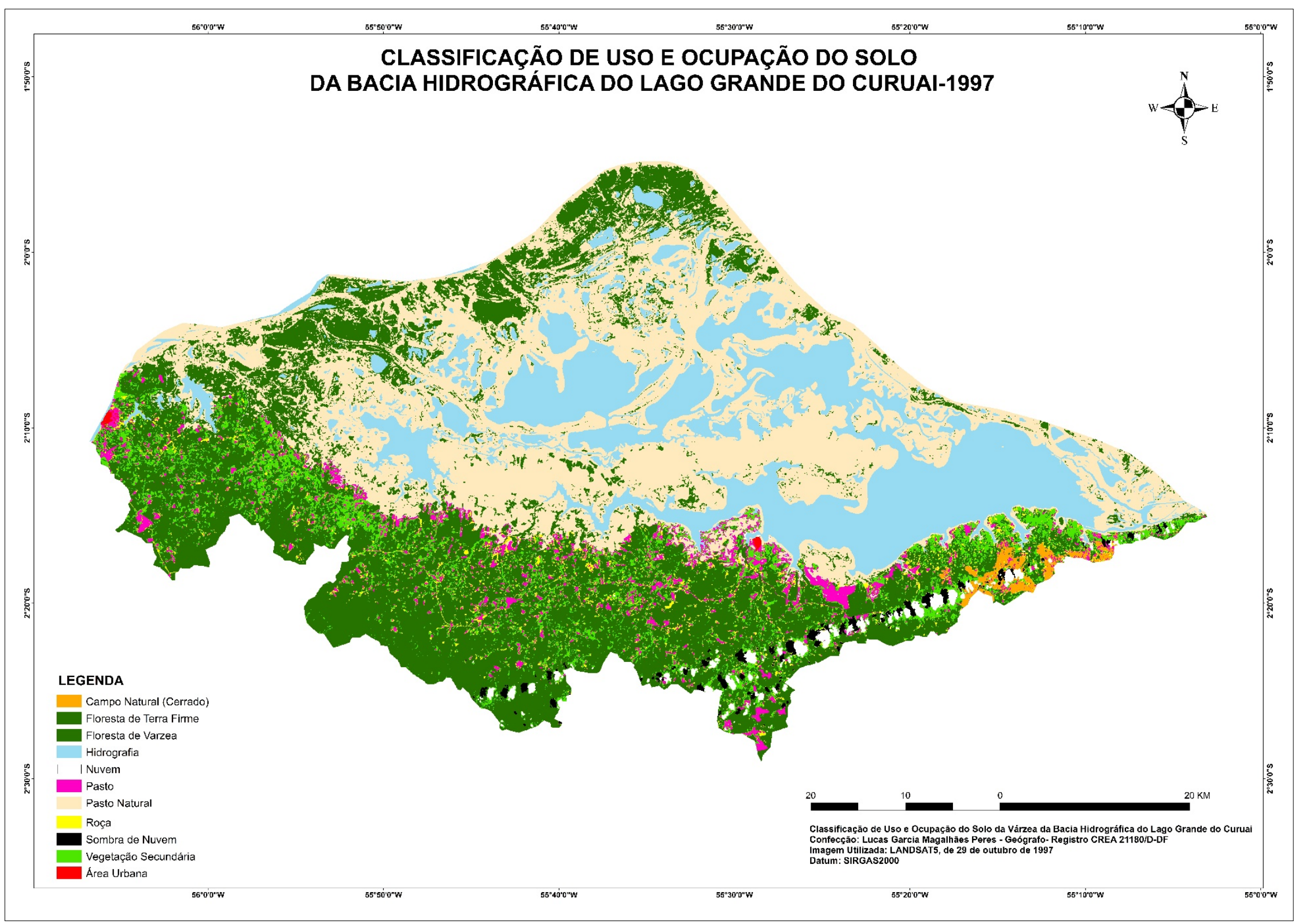

ANEXO I: Mapa de Classificação de Uso e Cobertura do Solo - 1997 


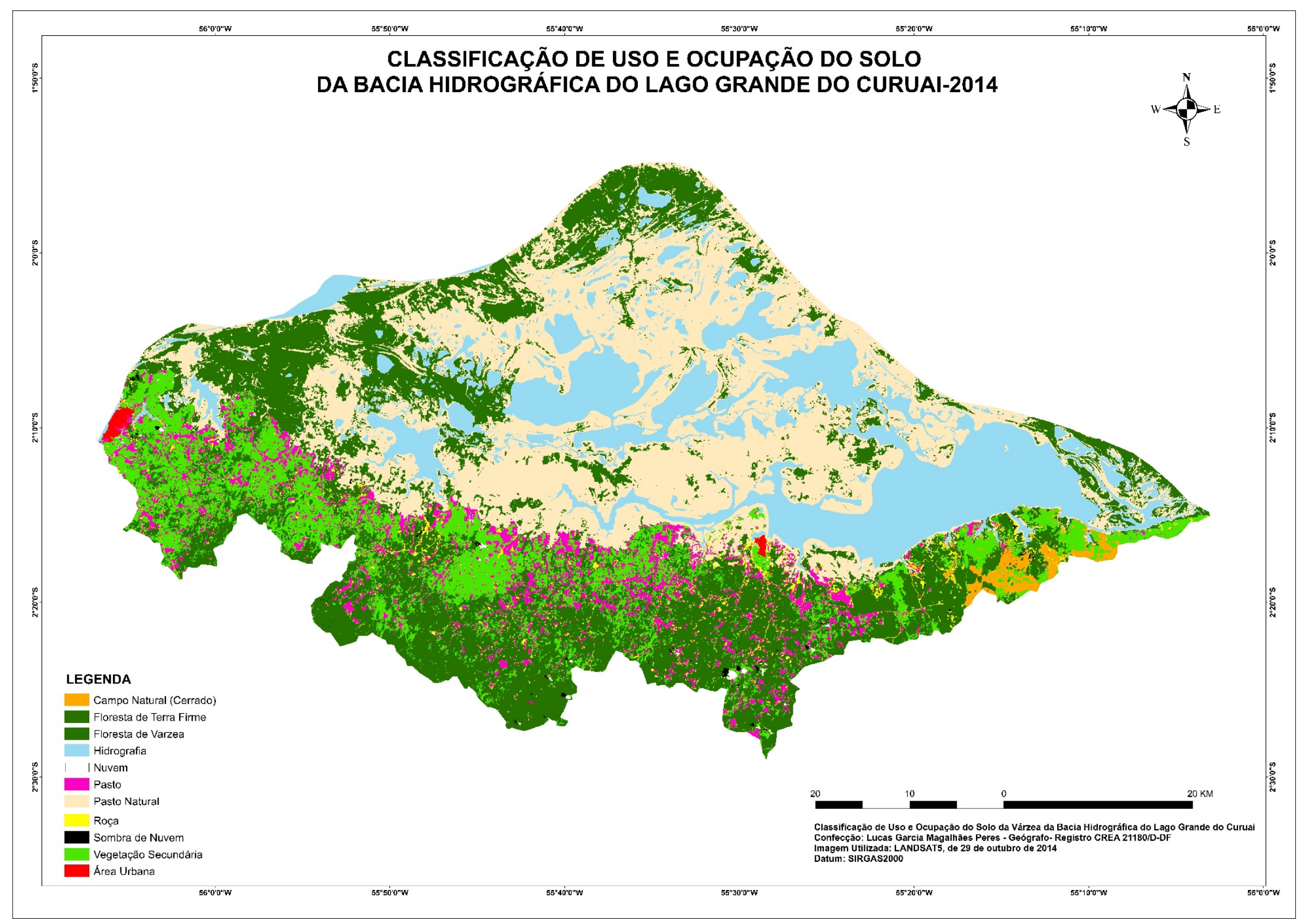

ANEXO J: Mapa de Classificação de Uso e Cobertura do Solo - 2015 
ANEXO K: Esquematização das Paisagens e Ambientes da Bacia Hidrográfica do Lago Grande do Curuai. Fonte: Elaborado por AnneElisabeth Laques (2015).

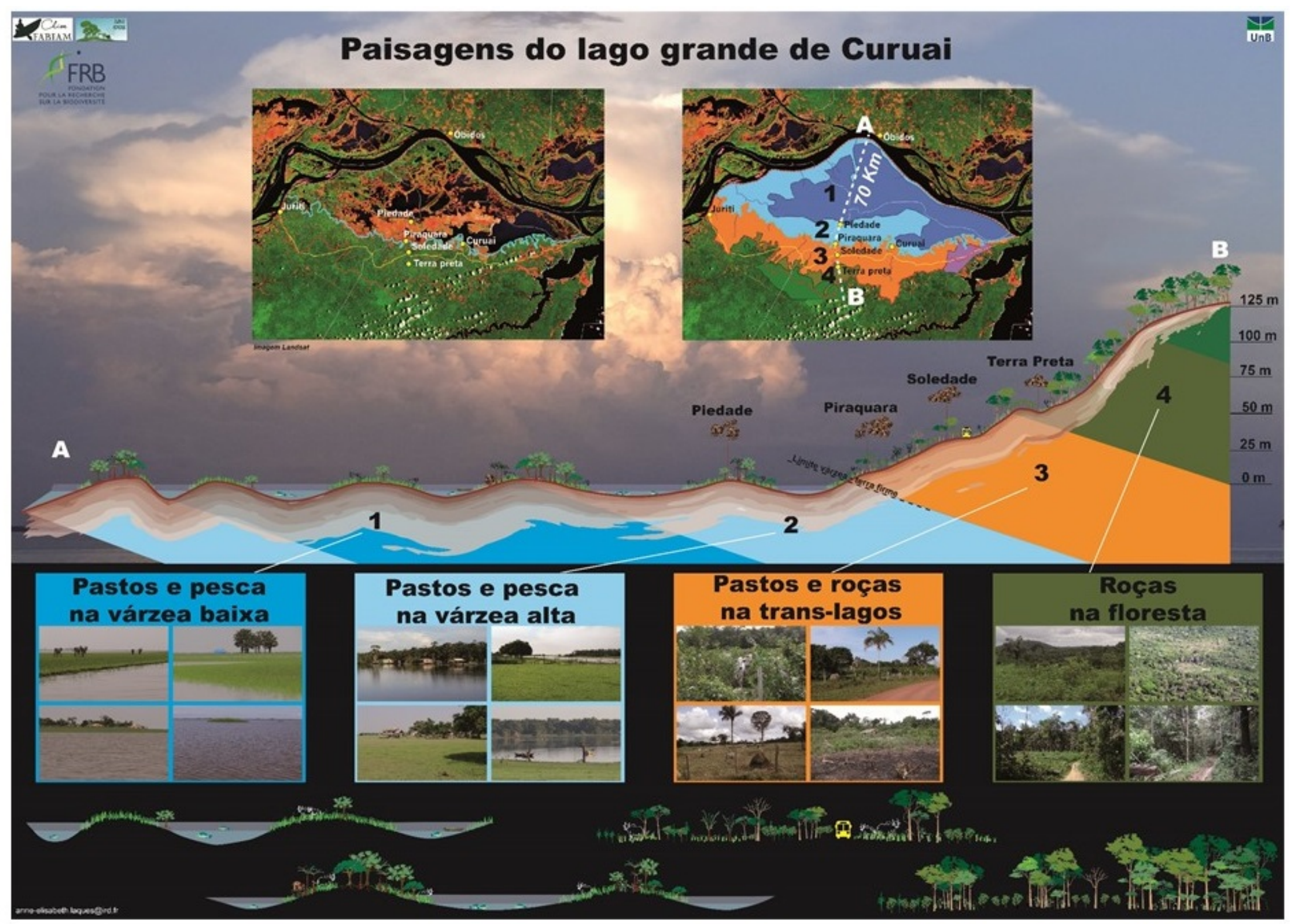


ANEXO L: Amostras das classes de uso e cobertura em imagens Landsat e do Google Earth. Fonte: elaborado pelo autor.

\begin{tabular}{|c|c|c|}
\hline $\begin{array}{l}\text { Exemplo de Áreas de } \\
\text { Treinamento das Classes } \\
\text { na Imagem LANDSAT }\end{array}$ & $\begin{array}{l}\text { Exemplo de Áreas de } \\
\text { Treinamento das Classes } \\
\text { no Google Earth }\end{array}$ & Descrição da Classe \\
\hline & & $\begin{array}{l}\text { Hidrografia: área inundadas livres de } \\
\text { cobertura vegetal, com diferentes } \\
\text { comportamentos espectrais devido a } \\
\text { composição da água }\end{array}$ \\
\hline & & $\begin{array}{l}\text { Área Urbana: Manchas urbanas } \\
\text { decorrentes da concentração } \\
\text { populacional, que formam lugarejos, } \\
\text { vilas ou cidades. }\end{array}$ \\
\hline & & $\begin{array}{l}\text { Floresta de } \text { Várzea: Árvores e } \\
\text { arbustos com altura dos dosséis } \\
\text { variando entre } 3 \text { e } 15 \text { metros, com } \\
\text { presença de água abaixo do dossel }\end{array}$ \\
\hline & & $\begin{array}{l}\text { Floresta de Terra Firme: Árvores e } \\
\text { arbustos de dossel elevado e massa } \\
\text { vegetal concentrada, visualizados em } \\
\text { terra firme, e com baixo padrão de } \\
\text { alteração antrópica }\end{array}$ \\
\hline & & $\begin{array}{l}\text { Pasto: Área de pastagem, onde domina } \\
\text { a vegetação herbácea e há cobertura de } \\
\text { gramíneas }\end{array}$ \\
\hline & & $\begin{array}{l}\text { Pasto Natural: Vegetação } \\
\text { herbácea/gramínea natural, que emerge } \\
\text { na época da seca, sendo utilizada para } \\
\text { pastagem em época de águas baixas }\end{array}$ \\
\hline & & $\begin{array}{l}\text { Roça: Área onde é praticada a } \\
\text { agricultura familiar, com rodízio de } \\
\text { cultura e queima em determinados } \\
\text { períodos; predominam o plantio de } \\
\text { mandioca e milho }\end{array}$ \\
\hline$\theta^{2}$ & & $\begin{array}{l}\text { Vegetação Secundária/Capoeira: } \\
\text { Áreas onde ocorreu o processo de } \\
\text { retirada da vegetação e se encontra em } \\
\text { processo de regeneração, sendo } \\
\text { ocasionalmente utilizadas. }\end{array}$ \\
\hline
\end{tabular}

